\title{
Determinants of price transmission
}

\author{
Dissertation \\ zur Erlangung des Doktorgrades \\ der Fakultät für Agrarwissenschaften \\ der Georg-August-Universität Göttingen
}

vorgelegt von

Carolin Simone Mengel

geboren in München

Göttingen, Juli 2014 
D7

1. Referent: Prof. Dr. Stephan von Cramon-Taubadel

2. Korreferent: Prof. Dr. Bernhard Brümmer

Tag der mündlichen Prüfung: 24. Juli 2014 


\section{Acknowledgements}

The writing of this dissertation has been one of the most significant challenges I have ever had to face. It is to the following people, that I owe my deepest gratitude. Without their support, patience and guidance, this study would not have been completed.

Stephan, I am most grateful that you gave me the opportunity to explore a challenging new field. Thank you for your trust, advice and support.

I thank the wonderful team at the International Food Policy Research Institute for hosting me with amazing kindness and a conducive working atmosphere in Dakar, Senegal.

This project would have been impossible without the support of the German Research Foundation (DFG) who funded the work of the GlobalFood Research Training Group.

Ich danke Ihnen von ganzem Herzen, Prof. Dr. Michael Bolle, Dr. Anneli Menninger, Dr. Kurt Graulich und Dr. Henze, für Ihre Unterstützung und Ihr Vertrauen in mich.

Je tiens aussi à exprimer ma reconnaissance envers toi, Pape Dembo Kouyaté. Tu m'a aidé à comprendre l'importance de ndank ndank moy japp golo ci niay. A Baraka ak dieuredieuf, sama jekker. Mbi fè.

Die Dissertation ist gewidmet: Elly, Elke, Wolfgang, Richard and Pape. 


\section{Table of Contents}

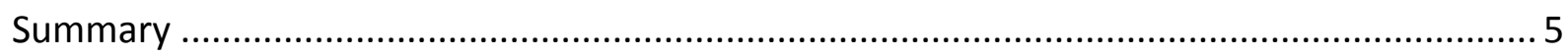

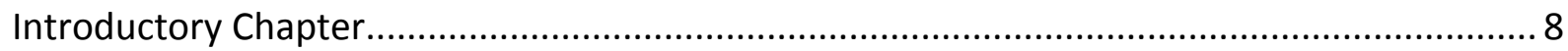

Chapter One

Price transmission from international to domestic markets .................................... 15

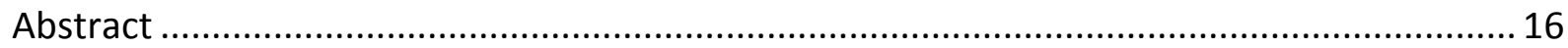

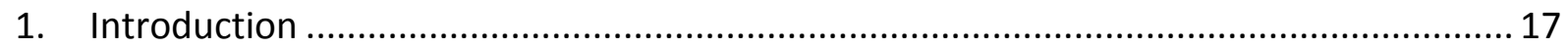

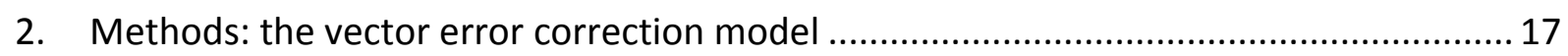

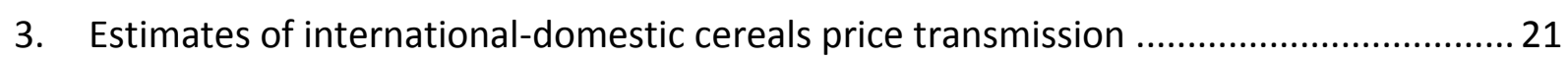

4. Analysis of the determinants of the strength of price transmission ............................... 30

5. Analysis of agreement in the direction of domestic and internat. price movements ..... 34

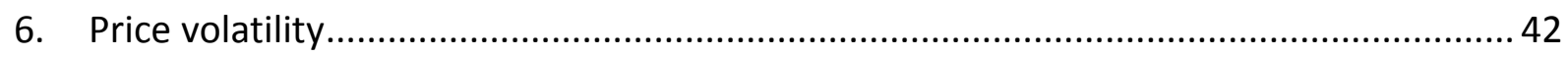

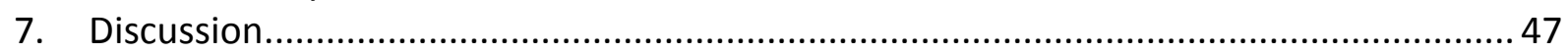

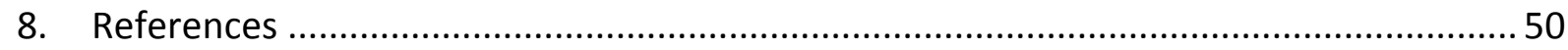

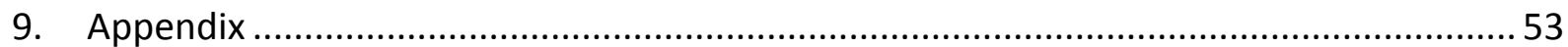

Chapter Two

Distance and border effects on price transmission- a meta-analysis ...........................62 62

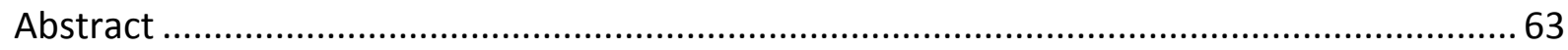

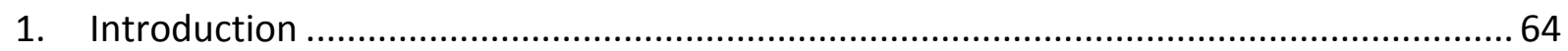

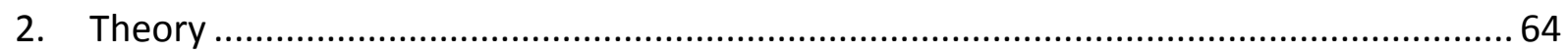

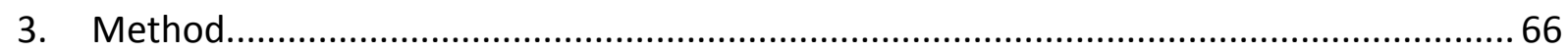

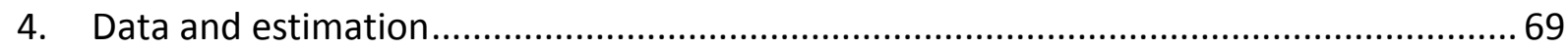

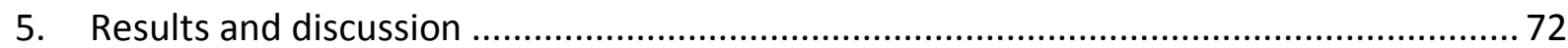

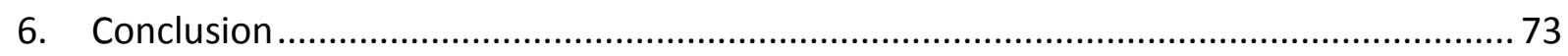

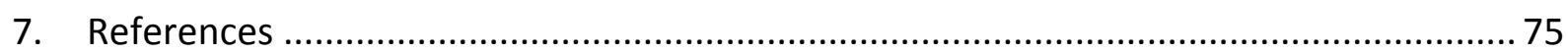

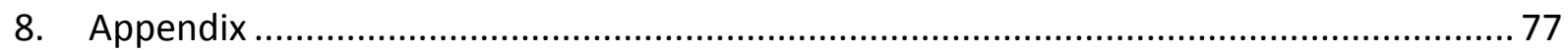

Chapter Three

Proximity and price co-movement in West African rice markets ................................. 85

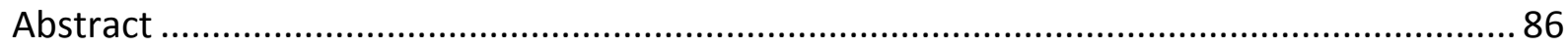

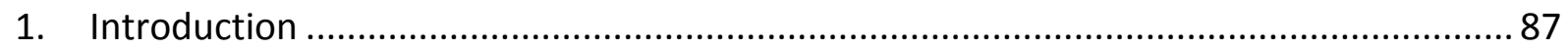

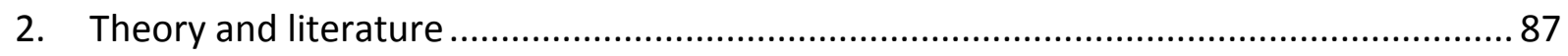

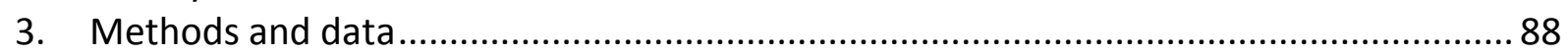

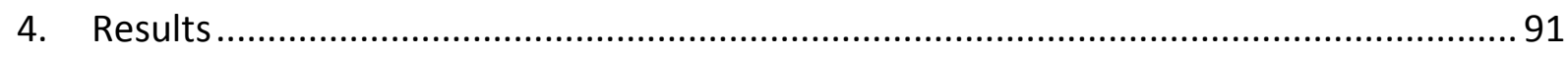

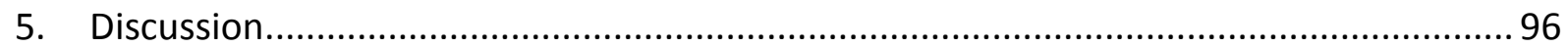

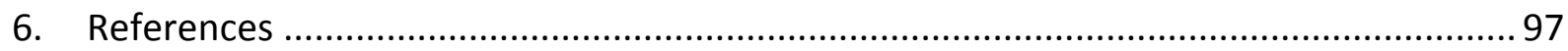

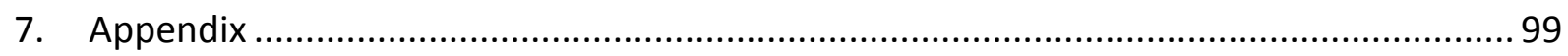

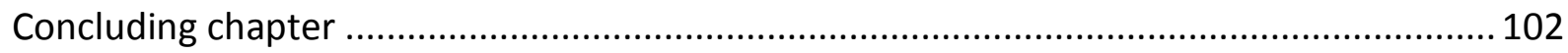


Summary 
This dissertation aims to improve our understanding on how prices changes are transmitted between markets and what determines these dynamics. We undertake three studies to shed light on price transmission from different perspectives. Based on price transmission estimates from literature and own data, we seek to identify regional- and product-specific differences and political, cultural and geographical influences. One central question is whether distance and international borders have an impact on price transmission between spatially separated markets. The analyses combine in innovative ways large-scale market analyses with up-to-date methods such as meta-analysis and threshold cointegration. The findings contribute with empirical evidence to the theoretical considerations about the determinants of price transmission.

The field of price transmission has spawned numerous econometric approaches to depict how prices in different locations or on different value chain levels affect each other. One standard concept is testing if price series move together over time (cointegration). Common parameters of interest are the strength of such a long-run price equilibrium (elasticity) and the speed of price adjustment to short-term deviations. In more recent applications, trade costs are incorporated as threshold effects in the price adjustment. The presented work deals with these aspects and seeks to isolate patterns in the results.

The first chapter on price transmission from international to domestic markets aims to improve our understanding of the extent and speed of the transmission of international cereal prices to local markets in developing countries. We analyze two samples of price transmission estimates, one extracted from a comprehensive literature sample of 31 published papers and studies on cereal price transmission and one containing of own estimates of cereal price transmission using the FAO's GIEWS dataset. We also present the results of a non-parametric analysis of price transmission in which we analyze the share of periods in which domestic and international prices have jointly increased or decreased. We find a higher share of cointegrated commodity market pairs in the literature sample (79\% compared to $43 \%)$. This may be due to publication bias. Cointegration is more prevalent for rice market pairs and less prevalent for maize market pairs. Both the literature and the GIEWS-based estimates point to average long-run price transmission coefficients (elasticities) of roughly 0.75 and average short-run adjustment parameters of roughly $0.09-0.11$. In most cases domestic prices adjust to deviations from the long-run price relationship, but international prices do not. The only notable exception to this rule is rice, which suggests that the determination of international rice prices differs fundamentally from the determination of international wheat and maize prices. In a subsequent meta-regression analysis we measure how much of the variation in the samples of price transmission estimates can be explained by country- or product-specific factors. However, this analysis fails to generate compelling results. An analysis of domestic price volatility reveals that median volatility has increased since July 2007.

In the second chapter, we conduct a comprehensive meta-analysis on the effect of distance and border effects on spatial price transmission. We use price transmission estimates for 1189 grain market pairs extracted from 57 studies and seek to explain them by airline distance and existence of an international border. The findings indicate distance and border effects on both price cointegration and price transmission. A border separating two markets reduces the probability of cointegration of price series by $23 \%$ compared with markets located in the same country. 1000 kilometers of airline distance reduces the probability of cointegration by $7 \%$. The speed of price adjustment is on average $13 \%$ slower in international than in intra-national market pairs. 1000 kilometers of distance within a country yields on average 6-20\% slower price adjustment. Distance effects are economically insignificant for international market pairs. Maize price pairs are less often cointegrated compared to rice prices and cointegration is most prevalent for barley. Price transmission is slowest in wheat markets. In peer reviewed studies price transmission is faster. However, the explanation need not be a publication bias but can also result from higher quality methodologies and consequently fewer misspecification errors. Moreover, we identify a set of model specifications that significantly affect 
price transmission estimates. The study contributes to the literature by presenting a first metaanalysis of spatial price transmission literature and providing insights into distance and border effects on spatial price transmission.

The third chapter explores the link between proximity and price cointegration in West African rice markets. Proximity is captured with variables for geographical, political and cultural distance. Linear and threshold cointegration is tested for a set of 756 rice market pairs in 6 West African countries, with threshold specifications accounting for transaction costs. Whether proximity matters for the results is determined in a second step with a multinomial logistic regression. The estimation produces robust and statistically significant evidence for a link between price transmission with airline and road distance, international borders, contiguity and a common language. We conclude that proximity matters for market integration processes in West African rice markets.

Overall, the findings from both literature and own estimations indicate that cointegration is more present between local and international markets, compared with local-local price pairs. In comparison to wheat and maize, the international rice market appears to be more dynamic with regard to price shocks. Furthermore, the evidence confirms the hypothesis of distance and border effects on spatial price transmission. Both decrease the likelihood of cointegration and the speed of price transmission, based on literature estimates and own data. We conclude that price shocks are less likely to spread out over longer distances and across borders. Moreover, more remote markets may not be able to absorb supply or demand shocks. This should be taken into account when targeting policies at food prices. Deeper market integration could potentially be achieved by lowering the trade and communication costs associated with distance and borders, for example via infrastructure measures, more efficient border processing or less restrictive trade barriers. 


\section{Introductory Chapter}


Food market integration is key for the ability of developing countries to cope with economics shocks and weather induced shocks in particular (Ravallion, 1986). Market integration is defined in different ways and the search for its determinants has consequently produced various empirical strands of literature. Trade economists typically measure the degree of market integration using country level trade flow data. Tinbergen (1962) introduced the gravity equation to international trade research to explain bilateral trade volumes between two countries by distance, market size and common characteristics. Ever since then, its empirical applications have produced positive evidence that the closer two countries are, the more they trade with one another. Other positive effects on trade volumes have been found for the market size, direct neighborhood and common characteristics such as languages, currencies and colonial ties. The empirical success of the gravity model is mainly attributed to theoretical considerations on trade costs related to these factors ${ }^{1}$. One important implication of the distance factor and the role of a common border is that neighboring countries become natural trading partners (Disdier \& Head, 2008), hence providing a strong argument in favor of regional integration.

As an alternative approach to measuring market integration, the use of price data has emerged with the field of price transmission. Fackler and Goodwin (2001) define market integration as "the measure of the degree to which demand and supply shocks arising in one region are transmitted to another region". While trade flow data capture the volume of actual commercial activity between markets, prices rather reflect supply and demand and can be used to model the transmission of shocks. Working with price data rather than trade flow data has three advantages. First, price data is more readily available at a spatially disaggregated level, e.g. for individual cities or villages. Such spatially disaggregated trade data rarely exists even for developed countries, thus posing a challenge for research on intranational market integration. Second, price data allows the analysis of different marketing levels. Retail prices can be related to international export prices or local producer prices. Firm-level trade data does not exist or is not available to the same extent. Third, the largest trade data base UN Comtrade ${ }^{2}$ mainly consists of yearly data, with monthly data only reaching back to the year 2010. Dynamic reactions to market shocks can be modeled more precisely with higher frequency data. Price series can often be obtained with monthly frequency and sometimes even weekly or daily frequency.

Price transmission analysis deals with the questions of whether, how completely and how quickly price signals are transmitted between markets or market levels. Price transmission as an empirical phenomenon has been more frequently examined since the global food price crisis in 2007/2008 and is back on the political agenda worldwide. Numerous studies concern themselves with empirical applications in the field. During the time of this study, the keywords "price transmission" result in 403 studies listed by the search engine AgEcon-Search. ${ }^{3}$ Fackler and Goodwin (2001) provide a comprehensive overview of the spatial price transmission literature. The mainly empirically driven field of price transmission has produced numerous methodological modifications and improvements to standard approaches. Most studies examine a product or a method in a particular context. The estimated parameters are interpreted with regard to the functioning of market structures and to a certain extent, into market integration. To a lesser extent studies also concern themselves with the determinants of price transmission. The findings are relevant for policy makers and add to an improved understanding of how these markets function.

\footnotetext{
${ }^{1}$ A discussion of trade costs is provided in the third chapter in relation to West African trade integration.

${ }^{2}$ http://comtrade.un.org/ (accessed on May 19, 2014)

3 http://ageconsearch.umn.edu/ (accessed on May 19, 2014)
} 
In this dissertation, we are interested in spatial price transmission ${ }^{4}$ together with a hybrid form, the transmission from the world market to the domestic level. For the latter case, the distinction is not straightforward. On the one hand, physical trade covering distance is required to bring the commodity from the export market to the consumer market. This calls for the definition of spatial price transmission. On the other hand, international commodities undergo some repackaging, marketing and distributing before they reach the local consumer. Some processing may be done in the case of raw products, for example from wheat to flour. Value is typically added to a product along the value chain and reflected in the final price. This is understood as a case of vertical price transmission. Price transmission from the world market to the local level combines elements from both spatial and vertical price transmission.

What determines price transmission depends on the setting and market structure. Several studies have focused on the influence of market power on price transmission along the value chain (Abdulai, 2000; Meyer \& von Cramon-Taubadel, 2004; von Cramon-Taubadel, 1998). Direct trade is the most important channel for spatial price transmission, following the spatial arbitrage condition, but it is not indispensable. Price transmission may also occur in the absence of trade (Ihle, Amikuzuno, et al., 2010; Stephens et al., 2012). Amikuzuno and Donkoh (2012) compare the speed of price transmission of national tomato trade periods with cross-border trade periods. They attribute a difference in the estimated coefficients to distance and borders. Ihle et al. (2010) find similar effects in a study on East African maize markets. The authors estimate the speed of price adjustment for 77 pairs of markets and regress the results on distance and several border variables. A strong negative effect for crossing Tanzanian borders is attributed to the potential effect of export bans. Hernandez-Villafuerte (2011) also finds distance measured in travel hours as significant variable for determining the elasticity of price transmission Brazilian rice markets. The seminal paper of Goodwin and Piggott (2001) changed the landscape in the field of price transmission. For the first time, transaction costs were incorporated in the modeling process as a threshold with the speed of price transmission changing for larger price changes. Price differentials exceeding these costs trigger a switch in the speed of price transmission. We conclude that transaction costs are determinants for market integration, together with the related factors distance and borders.

Overall, there is however still a lack of theoretical underpinnings supported by empirical evidence on the drivers of price transmission. Most applications concentrate at the "how" of price transmission, while we are interested in the "why". We want to contribute with three chapters in this dissertation. We seek to identify patterns and drivers of price transmission, both in the literature and in own estimations. To this end, we focus on developing countries and the main staple crops rice, wheat and maize. The analysis comprises international and domestic markets, and we use secondary data as well as estimates from the literature. Overall, we take different perspectives and employ different approaches, resulting into a number of insights about the literature and estimated price transmission in the international, domestic and West African context.

The dissertation is written as part of the research project GlobalFood - Transformation of Global Agri-Food Systems, funded as Research Training Group 1666 by the German Research Foundation

\footnotetext{
${ }^{4}$ The concept of spatial price transmission builds on the Law of One Price postulating a price equilibrium: arbitrage keeps the prices for the same commodity in spatially separated markets equal. A price wedge remains only with the transaction costs between the two markets. This can formally be expressed as: $P_{B}-P_{A} \leq T C_{A B}$

with $P_{A}$ and $P_{B}$ being the prices in market $\mathrm{A}$ and market $\mathrm{B}$ and $T C_{A B}$ being the transaction costs from market $\mathrm{A}$ to market $B$. This concept translates particularly well into the functioning of classical agricultural markets. In consequence, the concept is dominantly employed by agricultural economists, but also present in energy and financial market research. Price transmission analysis tests the spatial arbitrage hypothesis with static and dynamic regression techniques.
} 
(DFG) (www.uni-goettingen.de/globalfood). The participating researchers at the University of Göttingen combine approaches from agribusiness, agricultural economics, development economics and experimental economics in an interdisciplinary manner. The project deals with different aspects of the spread of high-value food products, public and private standards and the changing international and vertical market integration. Global agri-food chains have rarely been addressed from this particular perspective. In this context, this dissertation seeks to contribute to the understanding of the restructuring of global supply chains (research area A) and in particular on market structure and price transmission (subproject A2). The efficient functioning of markets plays a role for poverty, food security and economic development of urban and rural market areas and both for producers and consumers.

The first research project (chapter one) is partly based on the Terms of References for a report for the World Bank. The aim was to make use of a recently established large data set consisting of food price series in developing countries. The FAO Global Information and Early Warning System (GIEWS) data were collected and published under the FAO Initiative on Soaring Food Prices (IFSP). The research project was implemented in collaboration with three other researchers at the Chair of Agricultural Policy. My particular contributions concern the meta-analysis and the meta-regressions. Apart from descriptive price transmission results, we seek to identify general patterns and determinants of the estimates. The principal theme is the transmission of international price changes to the local level. The research questions ask how world market price changes transmit to wholesale and retail markets in 71 developing countries. Furthermore, what regional and product differences influence the results and what other drivers can be identified? To answer these questions, we estimate error correction models (ECMs) based on the GIEWS data and international reference prices. In addition, we extract complementing ECM estimates from the literature dealing with worldto-domestic price transmission. The results are presented and then regressed on a number of covariates, including product-specific and regional variables, trade and infrastructure variables. Furthermore, we conduct an analysis of the direction of price movements of both international and domestic markets. The main results indicate that the international rice market is more dynamic in response to price changes, while for other products the adjustment is primarily done by local markets. The regressions did not identify clear patterns in what determines transmission from the world market.

The second research project (chapter two) was motivated by the GlobalFood Principal Investigator Prof. Dr. Stephan von Cramon-Taubadel as part of the GlobalFood subproject A2. The aim was to explore distance and border effects in spatial price transmission by means of a meta-analysis of the respective literature. To isolate these effects, other factors are filtered out, such as the effect of study and model characteristics or product specific differences. The main topic is the spatial transmission of price changes in and between countries as it was estimated in existing studies. We formulate the research question whether geographical distance and international borders influence these estimates. We hypothesize that distance and borders impede trade and communication between markets, the two main channels for price transmission. We thoroughly review the large literature on spatial price transmission and extract comparable measures together with a set of explaining variables. We complement the obtained estimates from 57 studies with information on geodesic distance and borders. The main results indicate that distances and borders have as expected a robust negative effect on cointegration and the speed of price transmission between spatially separated markets.

The third research project (chapter three) originates from my motivation to explore a relevant food product for consumers and producers in a highly import-dependent region. This is the case for rice in West Africa, where local food production exists but imports dominate consumption in most countries. The main subject is the existence of spatial cointegration patterns with and without threshold effects in the adjustment. We test the hypothesis that these patterns can be partly 
explained by variables that capture different dimensions of proximity of markets. To this end, we employ a comprehensive set of cointegration tests to exhaust the possible specifications for spatial price transmission modeling, including incorporated threshold effects. The results are regressed on distance measures and information about borders, contiguity and common languages. The main results indicate robust distance and border effects on both linear cointegration and cointegration with threshold effects in the price adjustment. 


\section{References}

Abdulai, A. (2000). Spatial price transmission and asymmetry in the Ghanaian maize market. Journal of Development Economics, 63(2), 327-349.

Amikuzuno, J., \& Donkoh, S. A. (2012). Border effects on spatial price transmission between fresh tomato markets in Ghana and Burkina-Faso: Any case for promoting trans-border trade in West Africa? Journal of International Agricultural Trade and Development, 8(1), 81-98.

Disdier, A., \& Head, K. (2008). The puzzling persistence of the distance effect on bilateral trade. The Review of Economics and Statistics, 90, 37-48.

Fackler, P. L., \& Goodwin, B. K. (2001). Spatial price analysis. Handbook of Agricultural Economics, Volume 1, 971-1024.

Goodwin, B. K., \& Piggott, N. (2001). Spatial market integration in the presence of threshold effects. American Journal of Agricultural Economics, 83(2), 302-317.

Hernandez-Villafuerte, K. (2011). The relationship between spatial integration and geographical distance in Brazil. Annual Meeting of the European Association of Agricultural Economics (EAAE), Zürich, Switzerland, 1-37.

Ihle, R., Amikuzuno, J., \& Cramon-Taubadel, S. Von. (2010). Market integration with and without direct trade flows: The tomato in Ghana. Revue D'économie Du Développement, 24(1), 21-46.

Ihle, R., von Cramon-Taubadel, S., \& Zorya, S. (2010). Country and border effects in the transmission of maize prices in Eastern Africa: evidence from a semi-parametric regression model. Annual Meeting of the African Association of Agricultural Economists (AAAE), Cape Town, South Africa, $1-33$.

Meyer, J., \& von Cramon-Taubadel, S. (2004). Asymmetric price transmission: a survey. Journal of Agricultural Economics, 55(3), 581-611.

Ravallion, M. (1986). Testing market integration. American Journal of Agricultural Economics, 68(1), 102-109.

Stephens, E., Mabaya, E., von Cramon-Taubadel, S., \& Barrett, C. (2012). Spatial Price Adjustment with and without Trade. Oxford Bulletin of Economics and Statistics, 74(3), 453-469.

Tinbergen, J. (1962). Shaping the world economy: suggestions for an international economic policy. Twentieth Century Fund, New York, 262-293.

Von Cramon-Taubadel, S. (1998). Estimating asymmetric price transmission with the error correction representation: An application to the German pork market. European Review of Agricultural Economics, 25, 1-18. 
Chapter One 


\title{
Price transmission from international to domestic markets
}

\author{
Friederike Greb, Nelissa Jamora, Carolin Mengel, \\ Stephan von Cramon-Taubadel and Nadine Würriehausen ${ }^{5}$ \\ Department of Agricultural Economics and Rural Development \\ University of Göttingen
}

This report was prepared by the authors for the Rural Policies Thematic Group, the Agriculture and Rural Development Department, and the Poverty Reduction and Equity Unit of the World Bank, under the supervision of World Bank Senior Economist Sergiy Zorya. The opinions and conclusions expressed in this report do not necessarily represent those of the World Bank.

It is publicly available as GlobalFood Discussion Paper No. 15 on:

http://www.uni-goettingen.de/de/globalfood-discussion-paper-series/213486.html

\footnotetext{
5 Corresponding authors: Friederike Greb (friederike.greb@agr.uni-goettingen.de), Nelissa Jamora (nelissa.jamora@agr.uni-goettingen.de), Carolin Mengel (carolin.mengel@agr.uni-goettingen.de), Stephan von Cramon-Taubadel (scramon@gwdg.de), Nadine Würriehausen (nadine.wuerriehausen@agr.uni-goettingen.de) Financial support by the German Research Foundation (DFG) is gratefully acknowledged.
} 


\begin{abstract}
This study aims to improve our understanding of the extent and speed of the transmission of international cereal prices to local markets in developing countries. We analyze two samples of price transmission (PT) estimates, one extracted from a comprehensive literature sample of 31 published papers and studies on cereal price transmission and one containing of own estimates of cereal PT using the FAO's GIEWS dataset. We also present the results of a non-parametric analysis of PT in which we analyze the share of periods in which domestic and international prices have jointly increased or decreased.

We find a higher share of cointegrated commodity market pairs in the literature sample $(79 \%$ compared to 43\%). This may be due to publication bias. Cointegration is more prevalent for rice market pairs and less prevalent for maize market pairs. Both the literature and the GIEWS-based estimates point to average long-run PT coefficients of roughly 0.75 and average short-run adjustment parameters of roughly $0.09-0.11$. In most cases domestic prices adjust to deviations from the longrun price relationship, but international prices do not. The only notable exception to this rule is rice, which suggests that the determination of international rice prices differs fundamentally from the determination of international wheat and maize prices.

In a subsequent meta-regression analysis we measure how much of the variation in the samples of PT estimates can be explained by country- or product-specific factors. However, this analysis fails to generate compelling results. An analysis of domestic price volatility reveals that median volatility has increased since July 2007.
\end{abstract}

JEL:

C32, Q11, Q17, Q18

\title{
Keywords:
}

price transmission, cointegration, developing countries, agricultural trade, maize, rice, wheat, commodity prices 


\section{Introduction}

This study aims to improve our understanding of the extent and speed of the transmission of international cereal prices to local markets in developing countries. Spurred by the recent peaks in international food prices, many studies of world-to-domestic price transmission (PT) have been produced. However, to date no one has attempted to extract general lessons about the factors that determine the strength of PT from this extensive empirical literature. Neither has anyone attempted to extract such lessons by estimating PT processes with a consistent set of price data for a large number of countries using a uniform methodology.

To address this gap, we undertake three types of analysis in this study. First, we extract a sample of estimated measures of cereal PT from a comprehensive literature sample of published papers and studies. Second, we use the FAO's GIEWS dataset to estimate our own sample of measures of cereal PT. In a subsequent meta-regression analysis we measure how much of the variation in each of the resulting samples of PT estimates (the literature sample and the GIEWS sample) can be attributed to factors that might be expected to influence the strength of PT. Third, we present the results of simple, non-parametric analysis of price transmission using the GIEWS data. This analysis measures the share of periods in which domestic and international prices both either increased or decreased. This enables us to determine whether domestic prices at least tend to move in the same direction as international prices, even if they are not linked by a stable parametric relationship.

The rest of this study is structured as follows. In section 2 we begin by providing a brief summary of the vector error correction model that has been used in the great majority of empirical studies of PT over the last decade. In section 3 we then describe how we assembled our literature sample of PT estimates (section 3.1), and how we used the GIEWS dataset to generate our own set of PT estimates (section 3.2). In Section 4 we then describe the meta-analysis that we use to explain differences in the estimated strength of PT, beginning with a description of the covariates that we employ as possible determinants of PT (section 4.1) followed by a discussion of the results (section 4.2). Section 5 then presents the results of the non-parametric analysis of the direction of price movements. Section 6 presents some evidence on the volatility of domestic compared with international prices for different cereals and regions, and section 7 concludes.

\section{Methods: the vector error correction model}

\subsection{The structure of the vector error correction model}

The study of PT for homogeneous commodities in space, or for a product as it is transformed along the stages of the marketing chain (e.g. wheat - flour - bread), has attracted the interest of agricultural economists for many decades (Meyer 2004). Early empirical studies of PT were based on simple correlation and regression analyses that did not account for dynamics and lead-lag relationships in price data (for a survey, see Fackler and Goodwin, 2001). In the course of the 1980s, these methods were increasingly replaced by dynamic regression models that include lagged prices (e.g. Ravallion, 1986) and studies based on the concept of Granger causality (Gupta and Mueller, 1982). The emerging cointegration literature highlighted several pitfalls associated with the regression analysis of price data. In particular, since price data are often non-stationary, regression can lead to spurious results (Hassouneh et al, 2012). The basic insight of the cointegration approach is that to avoid the pitfall of spurious regression one must test whether non-stationary prices series (also referred to as 'integrated' price series) are not only correlated with one another but are rather 'co-integrated'. Cointegrated means that there exists a linear combination of the non-stationary series that is itself stationary, in other words that the series share a common form of non-stationarity and cannot drift apart indefinitely. 
Ardeni (1989) published the first study of PT on agricultural markets based on cointegration methods. It is fair to say that with the exception of a comparatively small literature based on socalled parity bounds models (Barrett and Li, 2002) today essentially the entire empirical PT literature draws on cointegration methods and, in particular, the so-called vector error correction model (VECM). The VECM is a re-parameterization of the standard vector autoregressive (VAR) model which relates the current levels of a set of time series to lagged values of those series. A simple VECM that captures the interactions between international or world prices and domestic price takes the following form:

$$
\begin{aligned}
& \Delta p_{t}^{d}=\varphi_{1}+\alpha_{1} \underbrace{\left(p_{t-1}^{d}-\beta_{1} p_{t-1}^{w}\right)}_{\text {error correction term }}+\delta_{1} \Delta p_{t-1}^{w}+\rho_{1} \Delta p_{t-1}^{d}+\varepsilon_{1 t} \text { (a) } \\
& \Delta p_{t}^{w}=\varphi_{2}+\alpha_{2} \underbrace{\left(p_{t-1}^{d}-\beta_{1} p_{t-1}^{w}\right)}_{\text {error correction term }}+\delta_{2} \Delta p_{t-1}^{w}+\rho_{2} \Delta p_{t-1}^{d}+\varepsilon_{2 t} \text { (b). }
\end{aligned}
$$

where

$p_{t}^{d}$ is the domestic price;

$p_{t}^{w}$ is the world price; and

$\varphi, \alpha, \beta, \delta$, and $\rho$ are parameters to be estimated.

In matrix notation, and allowing for more than one lag of the price difference terms, this VECM can be written compactly as:

$$
\left[\begin{array}{l}
\Delta p_{t}^{d} \\
\Delta p_{t}^{w}
\end{array}\right]=\left[\begin{array}{l}
\varphi_{1} \\
\varphi_{2}
\end{array}\right]+\left[\begin{array}{l}
\alpha_{1} \\
\alpha_{2}
\end{array}\right]\left[\begin{array}{ll}
1 & \beta_{1}
\end{array}\right]\left[\begin{array}{c}
p_{t-1}^{d} \\
p_{t-1}^{w}
\end{array}\right]+\sum_{i=1}^{k}\left[\begin{array}{ll}
\delta_{1 i} & \rho_{1 i} \\
\delta_{2 i} & \rho_{2 i}
\end{array}\right]\left[\begin{array}{c}
\Delta p_{t-i}^{w} \\
\Delta p_{t-i}^{d}
\end{array}\right]+\left[\begin{array}{c}
\varepsilon_{1 t} \\
\varepsilon_{2 t}
\end{array}\right]
$$

From the perspective of empirical PT analysis, the main advantage of the VECM over the VAR is that it separates the long-run equilibrium (or 'cointegrating') relationship between $p^{w}$ and $p^{d}-$ which is captured by the error correction term $\left(p_{t-1}^{d}-\beta_{1} p_{t-1}^{w}\right)$ - from the short-run dynamics that ensure that any deviations from this long-run equilibrium are 'corrected' and thus only temporary. The key parameters in the VECM are $\beta_{1}$, which describes how one price reacts to changes in the other in the long run ${ }^{6}$, and the so-called 'adjustment' parameters $\alpha_{1}$ and $\alpha_{2}$. If $p^{w}$ and $p^{d}$ are cointegrated, then $\alpha_{1}$ and $\alpha_{2}$ must have negative and positive signs, respectively. If this is the case, then if for example $p^{d}$ becomes too large relative to $p^{w}$ and the error correction term is correspondingly positive, a decrease in $p^{d}$ in the first equation of the VECM, and an increase in $p^{w}$ in the second equation, will drive the prices back towards their long-run equilibrium. One-to-one price transmission in the long run requires that $\beta_{1}=1$, while $0<\left|\alpha_{i}\right| \leq 1$, with large (small) values of $\alpha_{1}$ and $\alpha_{2}$ indicating that errors are corrected rapidly (slowly). ${ }^{7}$

Figure 1 outlines the basic empirical strategy for estimating PT. The first step is to determine whether the individual price series $p^{w}$ and $p^{d}$ are both non-stationary (also referred to as 'integrated' or 'I(1)'). This is usually carried out using the ADF (Dickey and Fuller, 1979) and KPSS tests (Kwiatkowski et al., 1992). If the prices are not both I(1), they cannot be cointegrated. If they are both stationary or 'I(0)' they can be studied using Auto-Regressive Distributed Lag (ARDL) models. If the series are both I(1), the null hypothesis that they are not cointegrated can be tested using a two-step OLS procedure proposed by Engle and Granger (1987) or a maximum likelihood procedure developed by Johansen

\footnotetext{
${ }^{6}$ If estimation is based on prices in logarithms then $\beta_{1}$ can be interpreted as the long-run elasticity of price transmission.

${ }^{7}$ The speed of error correction captured by the magnitude of an adjustment parameter must be interpreted relative to the frequency of the data that is used to estimate it. An $\alpha$ of 0.4 estimated with annual data implies that $40 \%$ of any deviation from long-run equilibrium is corrected within the space of one year. An $\alpha$ of 0.25 estimated with monthly data is smaller in magnitude but would nevertheless lead to over $95 \%$ correction of any deviation from long-run equilibrium in the course of one year. Some authors transform $\alpha^{\prime}$ s into so-called half-lives that indicate how many units of time are required for the correction of one-half of a deviation from the long-run equilibrium. An $\alpha$ of 0.25 estimated with monthly data corresponds to a half-life of 2.41 months.
} 
(1988). If the null of no cointegration is rejected, the VECM in equation (2) can be estimated, again using methods proposed by Engel and Granger or Johansen. Finally, the resulting estimates of $\beta$ and $\alpha$ are interpreted.

Figure 1: Conceptual framework for assessing price transmission and market integration

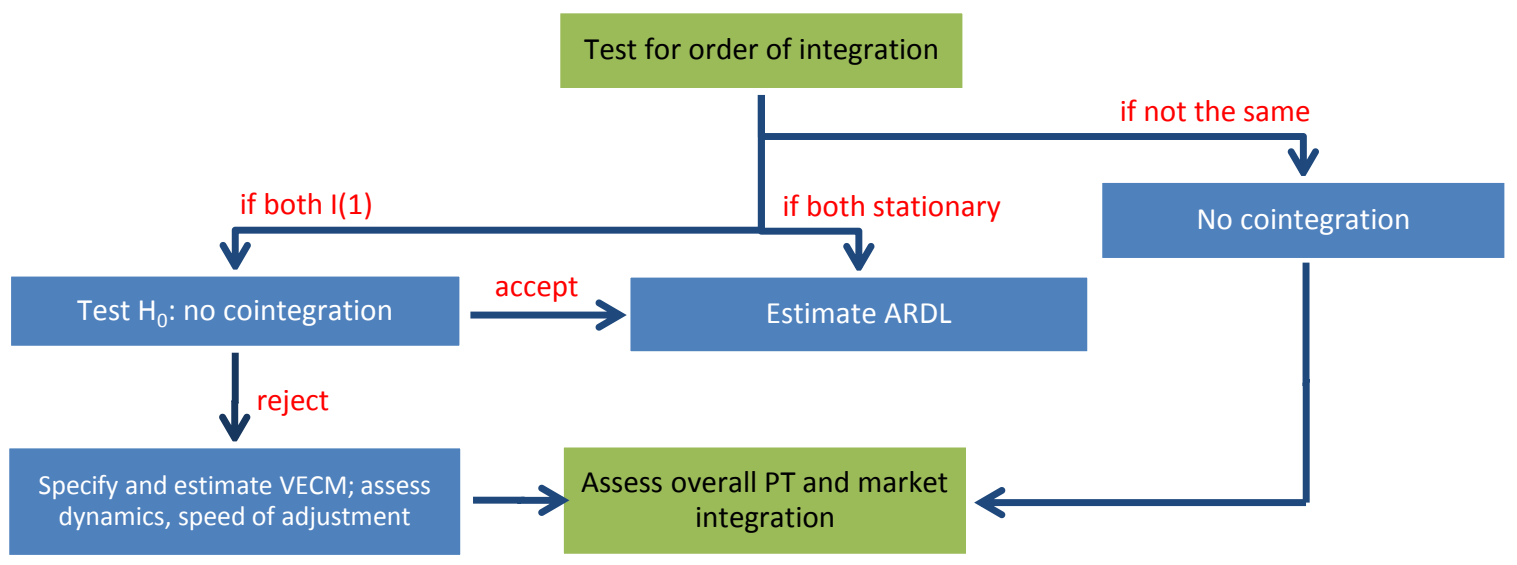

Source: Own depiction based on Rapsomanikis et al. (2003).

\subsection{Limitations of the vector error correction model, and alternatives}

While the VECM underlies most empirical work in PT analysis, it is restrictive is some settings. In particular, the VECM in equation (2) is linear in two senses (Hassouneh et al, 2012). First, it is linear in the sense that all of the parameters in the model are assumed to be constant over the entire sampling period. Second, it is linear in the sense that the dependent variables react linearly to changes in the independent variables. Numerous studies have shown that in many applications one or both of these types of linearity cannot be expected to hold (Hassouneh et al., 2010; Serra and Goodwin, 2003; Serra et al. 2006; von-Cramon-Taubadel, 1998; von Cramon-Taubadel and Amikuzuno, 2012).

For our purposes, the first type of linearity is especially restrictive. The PT relationship that links an international price to a country's domestic market price need not be constant over time. Changes in the country's trade policy (for example an increase or reduction of import tariffs) can alter the nature of the PT relationship, as can a switch from a net export to a net import position. Furthermore, spatial equilibrium theory (Takayama and Judge, 1971) predicts that short-run price adjustments due to arbitrage will take place only if the difference between international and domestic prices exceeds a threshold that is determined by transport and transaction costs (Barrett and Li, 2002). If the difference between prices is less than this threshold, there is no incentive for traders to engage in arbitrage, and prices can move independently of one another.

In such cases PT will be characterized by different so-called 'regimes' (for example, one regime before and one regime after an import tariff change; or one regime for the net export situation, and one for the net import situation). In recent years several models of regime-dependent PT have been developed and applied in the literature. Most of these can be described as piecewise linear models in which each regime is characterized by a standard VECM as in equation (2) above, and some trigger or transition mechanism determines when the model jumps from one regime to another. This trigger can be exogenous (e.g. coinciding with the date of a policy change) or endogenous (e.g. determined 
by whether the distance between the international and the domestic prices exceeds a certain threshold). Hassouneh et al. (2012) review a number of the regime-dependent PT models that are common in current research, including the threshold VECM (Goodwin and Piggott, 2001), the asymmetric VECM (von Cramon-Taubadel, 1998), and the smooth transition VECM (Teräsvirta, 1994).

Estimating regime-dependent PT models is considerably more complicated than estimating a standard VECM. Some of these models require additional exogenous variables in addition to the endogenous prices, for example information on the timing of policy changes or other exogenous shocks that lead to regime changes. Others regime-dependent models such as the threshold VECM can be estimated using prices alone, but require additional information and testing to determine the appropriate number of thresholds. ${ }^{8}$ Finally, there is no unified testing framework for comparing these regime-dependent models with one another.

Authors who are interested in analyzing PT in a specific product/country setting, or who use such a specific setting to illustrate a new regime-dependent PT model that they have developed or refined, can afford to engage in the additional data collection, specification, testing and interpretation that this entails. As outlined in section 3.2 below, however, the FAO GIEWS data provides us with domestic price series for three main cereal products (maize, rice and wheat) in 71 countries. It is beyond the scope of this study to carry out detailed regime-dependent PT analysis for each of these individual settings. Instead, we are obliged to use a comparatively simple PT model, such as the VECM, the estimation of which can be automated to permit the analysis of a large number of domestic-international price pairs. We recognize that the simple VECM specification in (2) will not be appropriate for all of the domestic-international price pairs in the GIEWS data. The additional insights that can be generated by estimating PT for a large number of price pairs and then analyzing the resulting cross-section sample of results come at the cost of a necessarily simple method of analysis that is not appropriate for each of these pairs individually.

In an attempt to deal with the shortcomings of the simple VECM, we propose two alternative methods of analysis. First, to allow for at least one possible source of non-linearity we modify the basic VECM in equation (2) to include a structural break which we postulate to have taken place in July 2007. This roughly corresponds to the beginning of the first agricultural price peak and the beginning of the recent phase of increased volatility on international commodity markets. Hence, we estimate the following model which allows the nature of price transmission between international and domestic cereal prices to change with the onset of higher and more volatile price in recent years. The resulting specification is as follows, where the superscript * distinguishes between pre-break and post-break parameters:

$$
\left[\begin{array}{l}
\Delta p_{t}^{d} \\
\Delta p_{t}^{w}
\end{array}\right]=\left\{\begin{array}{l}
{\left[\begin{array}{l}
\alpha_{1} \\
\alpha_{2}
\end{array}\right]\left[\begin{array}{ll}
1 & \beta_{1}
\end{array}\right]\left[\begin{array}{l}
p_{t-1}^{d} \\
p_{t-1}^{w}
\end{array}\right]+\sum_{i=1}^{k}\left[\begin{array}{ll}
\delta_{1 i} & \rho_{1 i} \\
\delta_{2 i} & \rho_{2 i}
\end{array}\right]\left[\begin{array}{l}
\Delta p_{t-i}^{d} \\
\Delta p_{t-i}^{w}
\end{array}\right]+\left[\begin{array}{l}
\varphi_{1} \\
\varphi_{2}
\end{array}\right]+\left[\begin{array}{l}
\varepsilon_{1 t} \\
\varepsilon_{2 t}
\end{array}\right], t<\text { July } 2007} \\
{\left[\begin{array}{l}
\alpha_{1}^{*} \\
\alpha_{2}^{*}
\end{array}\right]\left[\begin{array}{ll}
1 & \beta_{1}^{*}
\end{array}\right]\left[\begin{array}{l}
p_{t-1}^{d} \\
p_{t-1}^{w}
\end{array}\right]+\sum_{i=1}^{k}\left[\begin{array}{ll}
\delta_{1 i}^{*} & \rho_{1 i}^{*} \\
\delta_{2 i}^{*} & \rho_{2 i}^{*}
\end{array}\right]\left[\begin{array}{l}
\Delta p_{t-i}^{d} \\
\Delta p_{t-i}^{w}
\end{array}\right]+\left[\begin{array}{l}
\varphi_{1}^{*} \\
\varphi_{2}^{*}
\end{array}\right]+\left[\begin{array}{l}
\varepsilon_{1 t}^{*} \\
\varepsilon_{2 t}^{*}
\end{array}\right], t \geq \text { July } 2007}
\end{array}\right.
$$

Equation (3) is thus a regime-dependent VECM that links two standard VECMs, one for the period prior to July 2007, and one for the period thereafter. To check whether July 2007 is a plausible cutoff, we applied the Gregory and Hansen (1996) test of the null of no cointegration against the alternative of cointegration with a possible regime shift to each domestic/international price pair in the GIEWS data. Figure 2 shows the distribution of the break dates selected by the Gregory and Hansen test. While there is evidence of regime shifts in some domestic/international price relationships in 2003/04 for rice and 2004/05 for maize, for all three products (rice, maize and

\footnotetext{
${ }^{8}$ Furthermore, Greb et al. (2011) demonstrate that the maximum likelihood method used to estimate threshold VECMs in the literature to date is biased.
} 
wheat) by far the most regime shifts are indicated in 2007/08. July 2007 therefore appears to be a reasonable choice for the cut-off date in the regime-dependent VECM in equation (3).

Our second alternative to the standard VECM abandons the assumption of a parametric relationship between domestic and international prices entirely. Instead, we simply measure how often domestic and international prices have increased or decreased together in the past, and how often they have moved in opposite directions. Hence, for each of the GIEWS price series in each month we code whether it has increased or decreased. We do the same thing for the corresponding international price and then count the number of agreements (i.e. months in which both the domestic price and the corresponding international price increased or decreased) and the number of disagreements (i.e. months in which one price increased while the other decreased). The result is the simplest possible measure of price co-movement that indicates how often producers and consumers on domestic markets are at least receiving the correct qualitative price signals. To account for possible delays in price responses and short-run fluctuations we repeat this analysis using quarterly and annual price changes, and we also modify the analysis with monthly data to measure the agreement between the direction of international price changes in month $t$ and the direction of domestic price changes in month $t+1$.

Figure 2: The distribution of break dates chosen by the Gregory and Hansen (1996) test

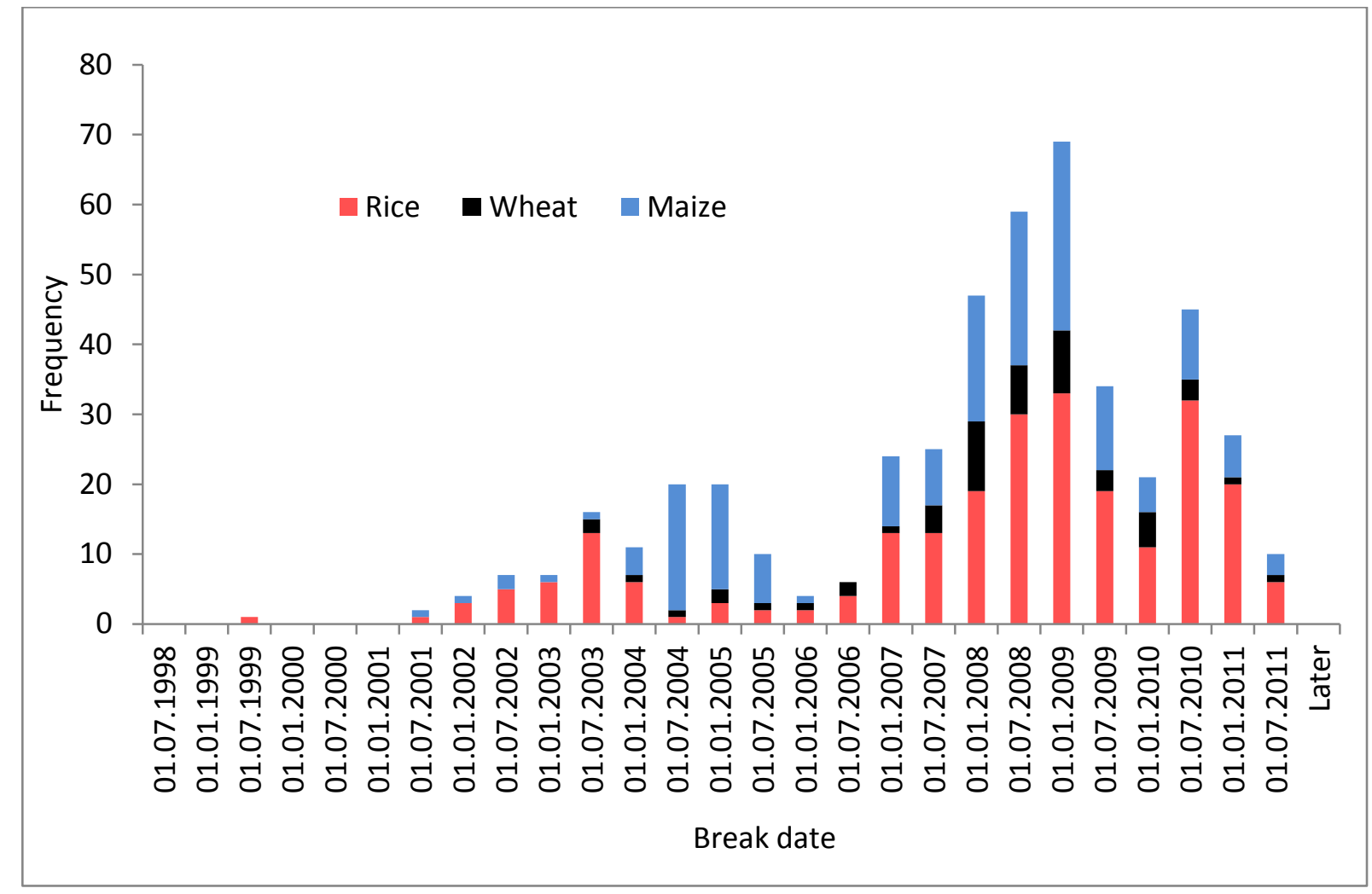

Source: Own calculations with GIEWS price data.

\section{Literature-based and GIEWS data-based estimates of international- domestic cereals price transmission}

Following the discussion of methods in the previous section, we follow a three-part approach to generate insights into the nature of international to domestic PT for major cereal products. First, many studies that report VECM estimates for international to domestic PT have been published in recent years. As outlined in section 3.1, we have collected these studies and analyze the estimates of $\beta$ and $\alpha$ that they report. Second, using the extensive FAO GIEWS price data set, we generate our 
own estimates of $\beta$ and $\alpha$ for a large number of countries using the VECM in equation (2) and the regime-dependent VECM in equation (3). This work is outlined in section 3.2 below. Third, using the GIEWS price data we carry out the non-parametric analysis of agreements and disagreements in price increases and decreases described above. In all three types of analysis we consider maize, rice and wheat.

Each of these approaches has its advantages and disadvantages. Most studies in the literature only report a few PT estimates, typically for a single product and one or relatively few counties. As a result, the estimates in these studies can be expected to reflect detailed work by authors who have a comprehensive understanding of the markets that they study, and who have undertaken careful specification searches, for example to determine appropriate lag-lengths for the VECMs that they estimate, etc. As discussed above, the FAO GIEWS price data includes hundreds of price series. Hence, we are obliged to automate the estimation and work with simple uniform specifications that may not be appropriate in all cases. On this count the literature-based estimates might be more reliable.

The other side of this coin, however, is publication bias. The literature might be biased towards studies that report evidence of cointegration, and authors might be inclined to experiment with different specifications and only report on those that provide such evidence. Indeed, in some of the studies we surveyed, the authors openly state that they only report results for those markets for which they find evidence of cointegration. In this regard, our own estimates with the GIEWS price data might provide a more representative picture of PT (or the lack thereof) around the world. Moreover, a problem that is common to all meta-analyses of existing publications is that results can be presented in numerous ways and standards of documentation often differ considerably from study to study. In our context, some studies present only $\beta$ 's and others only $\alpha$ 's; some work with prices data in levels, others with price series in logarithms; and not all studies clearly explain the nature of the price data that they use (for example, what international reference price was employed).

Finally, the advantage of the analysis of agreements and disagreements in price increases and decreases is that it is free of any assumptions about the functional relationship between domestic and international prices. If this relationship has been subject to numerous changes over time, imposing a parametric model such as the VECM (with or without a single structural break) will lead to inappropriate results. The non-parametric approach avoids this pitfall. However, it also produces results that are correspondingly less informative. Even if we find that domestic and international prices show a tendency to increase and decrease together, this does not mean that producers and consumers on domestic markets are receiving undistorted price signals; it could be that the magnitude of the domestic price changes is considerably larger (or smaller) on average than the magnitude of the corresponding international price changes.

\subsection{Estimates of cereal price transmission in the literature}

The set of literature-based estimates of cereal PT is based on a thorough literature search including journal publications, institutional reports, conference papers, thesis and dissertations. We consider only studies that estimate error correction models of PT from international to domestic markets for maize, rice and wheat. We therefore exclude studies that assess only cointegration, causality, or pass-through effects. We also exclude studies that analyze domestic PT, i.e. within country markets, or bilateral country PT. In the end, we consider the 31 studies listed in Appendix Table 1, 30 of which were published in the last 10 years. Since most studies cover more than one country/location, the 31 studies provide 678 individual estimates of PT, 215 for rice (32\%), 271 for wheat (40\%), and 192 for maize (28\%)

16 of the 31 studies consider one or two countries, while 15 consider between 3 and 15 countries. In total, the literature-based estimates of PT cover 52 countries, 9 of which are in East Africa, 7 in West 
Africa, 14 in Asia, 13 in Latin America, 6 in Europe, 2 in North America, and 1 in Oceania. 15 of the 31 studies were published in institutional reports or as working/discussion papers, 8 were published in peer-reviewed journals, and the rest are conference papers, book chapters or theses/dissertations. 23 of the studies are based on monthly price data, while 5 use annual and 5 use weekly prices. 26 of the 31 studies analyze prices in logarithms, while the remaining 5 work with prices in levels. Beyond simple VECMs, 3 out of 31 studies also test for asymmetric price transmission (Meyer and von Cramon-Taubadel, 2004), 3 articles estimate so-called threshold VECMs (Goodwin and Piggott, 2001), and 3 consider both thresholds and asymmetry.

There is no consensus on what constitutes 'the' international or world price for a commodity such as maize, rice or wheat. However, certain prices or export markets do dominate (see Appendix Figures 1-3). In our literature sample, US No. 2 yellow FOB Gulf is used as the international price in $67 \%$ of all estimations involving yellow maize. Thailand export prices are used for $72 \%$ of all rice market pairs. While Thailand $5 \%$ broken dominate (55\%), several studies also use other qualities such as Thai $A 1$, Thai $100 \mathrm{~B}$, Thai $15 \%$, and Thai $35 \%$. For wheat a greater variety of international references prices are used, but $68 \%$ of the observations are based on US prices, and US No. 2 hard red winter (HRW) is used in $24 \%$ of all cases. The domestic price underlying $36 \%$ of the observations is a border price, but producer (21\%), wholesale (14\%), and retail (15\%) prices are also used.

\subsection{0wn estimates of cereal price transmission based on FAO GIEWS data}

The FAO Global Information and Early Warning System (GIEWS) food price data set was established in 2009 as part of the FAO Initiative on Soaring Food Prices (ISFP). ${ }^{9}$ The prices reported in GIEWS are collected from national official sources and non-official institutions. The GIEWS price series are monthly and most run through to the end of 2011; some start as early as 1995 , others as late as 2008. We impose a minimum length of 10 observations for a time series to be considered in our analysis and analyze PT between domestic and the following international prices:

- wheat -> US No. 2 HRW

- $\quad$ rice $->$ Thai $5 \%$

- yellow maize -> US No. 2 yellow Gulf

- white maize $->$ Randfontein (South Africa).

The GIEWS data includes a total of 57 domestic prices for wheat, 262 domestic prices for rice and 180 domestic prices for maize. As is the case with the literature sample, GIEWS mainly provides results for countries in Africa, Asia/Pacific and Latin America. However, while the literature sample also provides results for countries in Europe and North America, GIEWS only includes a small number of observations (7 of 499) for Europe. To estimate the VECMs in equation (2) and (3) above with the GIEWS data a decision about the number of lags $(k)$ to include must be reached. As shown in Table 1, the Akaike Information Criterion (AIC - Akaike, 1974) indicates that k=1 in the great majority of cases, so for simplicity we employ one lag throughout.

Table 1: The optimal number of lags to include in VECM estimation as indicated by the AIC

\begin{tabular}{|c|c|c|c|c|c|c|c|c|c|c|c|c|}
\hline \multirow{3}{*}{$\begin{array}{l}\text { Commodity } \\
\text { Maize }\end{array}$} & \multicolumn{12}{|c|}{ Number of lags } \\
\hline & \multicolumn{2}{|c|}{1} & \multicolumn{2}{|r|}{2} & \multicolumn{2}{|c|}{3} & \multicolumn{2}{|c|}{4} & \multicolumn{2}{|c|}{5} & \multicolumn{2}{|c|}{6} \\
\hline & 167 & $92.8 \%$ & 7 & $3.9 \%$ & 3 & $1.7 \%$ & 1 & $0,6 \%$ & 2 & $1.1 \%$ & 0 & $0 \%$ \\
\hline Rice & 185 & $70.6 \%$ & 44 & $16.8 \%$ & 13 & $5.0 \%$ & 10 & $3,8 \%$ & 5 & $1.9 \%$ & 5 & $1.9 \%$ \\
\hline Wheat & 45 & $78.9 \%$ & 9 & $15.8 \%$ & 2 & $3.5 \%$ & 1 & $1,8 \%$ & 0 & $0 \%$ & 0 & $0 \%$ \\
\hline
\end{tabular}

Source: Own calculations with GIEWS price data.

\footnotetext{
${ }^{9}$ We are grateful to David Hallam for providing us with this data in electronic form.
} 


\subsection{Comparing literature and GIEWS-based estimates of price transmission}

\subsubsection{Cointegration}

Tables 2 and 3 present information on the numbers and shares of international/domestic price pairs which are found to be cointegrated according to the literature sample and the GIEWS estimates, respectively. Overall, the literature sample suggests that international and domestic prices are cointegrated more often than is indicated by our own estimation with GIEWS data. $79 \%$ of all market pairs reported in the literature sample are cointegrated, compared with $55 \%$ in the GIEWS sample. This is presumably due to the literature bias discussed above, i.e. the fact that the literature tends to report findings of cointegration. The literature sample indicates the lowest prevalence of cointegration for East and West Africa compared with Asia/Pacific and especially Europe and the Americas, but this pattern is not confirmed by the GIEWS results. In the literature sample, the lower prevalence of cointegration for East and West Africa primarily is due to maize (46 and $58 \%$ shares of cointegration for East and West Africa, respectively) rather than rice, for which most African prices are cointegrated with international prices ( 83 and $73 \%$, respectively), or wheat, for which there are only 8 observations for Africa. In both the literature and the GIEWS results there is less frequent evidence of cointegration for maize than for rice. For wheat, however, the literature indicates that cointegration is relatively frequent ( $88 \%$ of all international/domestic price pairs), while the GIEWS results suggest that it is less so (44\%). However the wheat results in the literature are strongly influenced by a single study that produces over 100 observations for North America, all of which indicate that domestic and international prices are cointegrated.

Table 2: The prevalence of cointegration in the literature sample

\begin{tabular}{l|ccc|ccc|ccc|ccc}
\hline \multirow{2}{*}{ Region } & \multicolumn{4}{|c|}{ Maize } & \multicolumn{3}{c|}{ Rice } & \multicolumn{3}{c|}{ Wheat } & \multicolumn{3}{c}{ Total } \\
\cline { 2 - 12 } & $\begin{array}{c}\# \\
\text { obs. }\end{array}$ & $\begin{array}{c}\# \\
\text { coint. }\end{array}$ & $\begin{array}{c}\text { coint. } \\
\text { co }\end{array}$ & $\begin{array}{c}\# \\
\text { obs. }\end{array}$ & $\begin{array}{c}\# \\
\text { coint. }\end{array}$ & $\begin{array}{c}\text { \% } \\
\text { coint. }\end{array}$ & $\begin{array}{c}\# \\
\text { obs. }\end{array}$ & $\begin{array}{c}\# \\
\text { coint. }\end{array}$ & $\begin{array}{c}\text { \% } \\
\text { coint. }\end{array}$ & $\begin{array}{c}\# \\
\text { obs. }\end{array}$ & $\begin{array}{c}\# \\
\text { coint. }\end{array}$ & $\begin{array}{c}\% \\
\text { coint. }\end{array}$ \\
\hline East Africa & 107 & 49 & $\mathbf{4 6}$ & 24 & 20 & $\mathbf{8 3}$ & 8 & 5 & $\mathbf{6 3}$ & 139 & 74 & $\mathbf{5 3}$ \\
West Africa & 12 & 7 & $\mathbf{5 8}$ & 26 & 19 & $\mathbf{7 3}$ & 0 & 0 & - & 38 & 26 & $\mathbf{6 8}$ \\
Asia/Pacific & 25 & 17 & $\mathbf{6 8}$ & 93 & 79 & $\mathbf{8 5}$ & 28 & 17 & $\mathbf{6 1}$ & 146 & 113 & $\mathbf{7 7}$ \\
Latin America & 44 & 38 & $\mathbf{8 6}$ & 64 & 57 & $\mathbf{8 9}$ & 61 & 57 & $\mathbf{9 3}$ & 169 & 152 & $\mathbf{9 0}$ \\
Europe & 4 & 4 & $\mathbf{1 0 0}$ & 7 & 6 & $\mathbf{8 6}$ & 20 & 18 & $\mathbf{9 0}$ & 31 & 28 & $\mathbf{9 0}$ \\
North America & 0 & 0 & - & 1 & 1 & $\mathbf{1 0 0}$ & 122 & 122 & $\mathbf{1 0 0}$ & 123 & 123 & $\mathbf{1 0 0}$ \\
Oceania & 0 & 0 & - & 0 & 0 & - & 32 & 20 & $\mathbf{6 3}$ & 32 & 20 & $\mathbf{6 3}$ \\
\hline Total & 192 & 115 & $\mathbf{6 0}$ & 215 & 182 & $\mathbf{8 5}$ & 271 & 239 & $\mathbf{8 8}$ & 678 & 536 & $\mathbf{7 9}$ \\
\hline
\end{tabular}

Note: We report results of cointegration tests reported in the individual studies in the literature sample. There is no uniform methodology - different authors use different tests and levels of significance.

Source: Own calculations with literature sample. 
Table 3: The prevalence of cointegration in the GIEWS estimates

\begin{tabular}{|c|c|c|c|c|c|c|c|c|c|c|c|c|}
\hline \multirow[t]{2}{*}{ Region } & \multicolumn{3}{|c|}{ Maize } & \multicolumn{3}{|c|}{ Rice } & \multicolumn{3}{|c|}{ Wheat } & \multicolumn{3}{|c|}{ Total } \\
\hline & $\begin{array}{c}\# \\
\text { obs. }\end{array}$ & $\begin{array}{c}\# \\
\text { coint. } \\
\end{array}$ & $\begin{array}{c}\% \\
\text { coint. }\end{array}$ & $\begin{array}{c}\# \\
\text { obs. }\end{array}$ & $\begin{array}{c}\# \\
\text { coint. } \\
\end{array}$ & $\begin{array}{c}\% \\
\text { coint. }\end{array}$ & $\begin{array}{c}\# \\
\text { obs. }\end{array}$ & $\begin{array}{c}\# \\
\text { coint. } \\
\end{array}$ & $\begin{array}{c}\% \\
\text { coint. }\end{array}$ & $\begin{array}{c}\# \\
\text { obs. }\end{array}$ & $\begin{array}{c}\# \\
\text { coint. }\end{array}$ & $\begin{array}{c}\% \\
\text { coint. }\end{array}$ \\
\hline East Africa & 59 & 21 & 36 & 35 & 22 & 63 & 14 & 8 & 57 & 108 & 51 & 47 \\
\hline West Africa & 43 & 9 & 21 & 81 & 58 & 72 & 6 & 1 & 17 & 130 & 68 & 52 \\
\hline Asia/Pacific & 15 & 2 & 13 & 63 & 18 & 29 & 24 & 3 & 13 & 102 & 23 & 23 \\
\hline Latin America & 58 & 22 & 38 & 70 & 39 & 56 & 11 & 2 & 18 & 139 & 63 & 45 \\
\hline Europe & 4 & 1 & 25 & 1 & 1 & 100 & 2 & 0 & 0 & 7 & 2 & 29 \\
\hline North America & 0 & 0 & - & 0 & 0 & - & 0 & 0 & - & 0 & 0 & - \\
\hline Oceania & 0 & 0 & - & 1 & 1 & 100 & 0 & 0 & - & 1 & 1 & 100 \\
\hline Total & 179 & 55 & 31 & 251 & 139 & 55 & 57 & 14 & 25 & 487 & 208 & 43 \\
\hline
\end{tabular}

Note: Cointegration is determined by Johansen Test with 5\% significance level.

Source: Own calculations with GIEWS price data.

\subsubsection{Estimates of the long-run price transmission coefficient $(\beta)$}

Table 4 summarizes the average estimates of the long-run PT coefficient $\beta$ taken from the literature and GIEWS samples by cereal product and region, and Figures $2 \mathrm{a}$ and $2 \mathrm{~b}$ provide an overview of the averages by region and by cereal, respectively. On average the literature and the GIEWS estimates of $\beta$ are similar ( 0.74 and 0.76 , respectively). These averages indicate that on average changes in international prices are transmitted by roughly three-quarters to domestic prices. However, for all regions with the exception of West Africa, the GIEWS estimates are on average roughly 0.2 higher than the literature estimates, and Figure $2 a$ reveals that the literature average is boosted considerably by a large number of observations from North America with an average $\beta=0.89$. Otherwise, Figure $2 \mathrm{~b}$ shows that the average $\beta \mathrm{s}$ are similar for maize and rice, but that the GIEWS average for wheat is much higher than the corresponding average from the literature sample. These results change very little if only those product/country combinations are retained in the comparison for which there are observations in both the GIEWS and the literature samples (Appendix Table 3).

Table 4: Average estimates of the long-run PT coefficient $\beta$ taken the literature and GIEWS samples, by product and region

\begin{tabular}{l|c|c|c|c|c|c|c|c}
\hline & \multicolumn{2}{|c|}{ Maize } & \multicolumn{2}{c|}{ Rice } & \multicolumn{2}{c|}{ Wheat } & \multicolumn{2}{c}{ All three cereals } \\
\cline { 2 - 9 } & GIEWS & Lit. & GIEWS & Lit. & GIEWS & Lit. & GIEWS & Lit. \\
\hline Asia \& ME & 0.77 & 1.03 & 0.53 & 0.60 & 1.97 & 1.09 & 0.87 & 0.67 \\
E. Africa & 0.93 & 0.76 & 0.87 & 0.48 & 0.76 & 0.65 & 0.89 & 0.72 \\
W. Africa & 0.42 & 1.74 & 0.64 & 0.46 & 1.27 & - & 0.60 & 0.63 \\
Europe & 0.82 & 0.61 & 0.92 & 0.54 & 0.98 & 0.94 & 0.88 & 0.71 \\
L. America & 0.69 & - & 0.69 & 0.55 & 1.14 & - & 0.73 & 0.55 \\
N. America & - & - & - & 1.00 & - & 0.89 & - & 0.89 \\
Oceania & - & - & 0.91 & - & - & - & 0.91 & - \\
\hline All regions & 0.72 & 0.78 & 0.66 & 0.55 & 1.41 & 0.89 & 0.76 & 0.74 \\
\hline
\end{tabular}

Note: Averages by region and cereal weighted by the number of observations in each category.

Source: Own calculations with literature sample and GIEWS price data. 
Figure 2a: Average estimates of the long-run price transmission coefficient $(\beta)$ by region

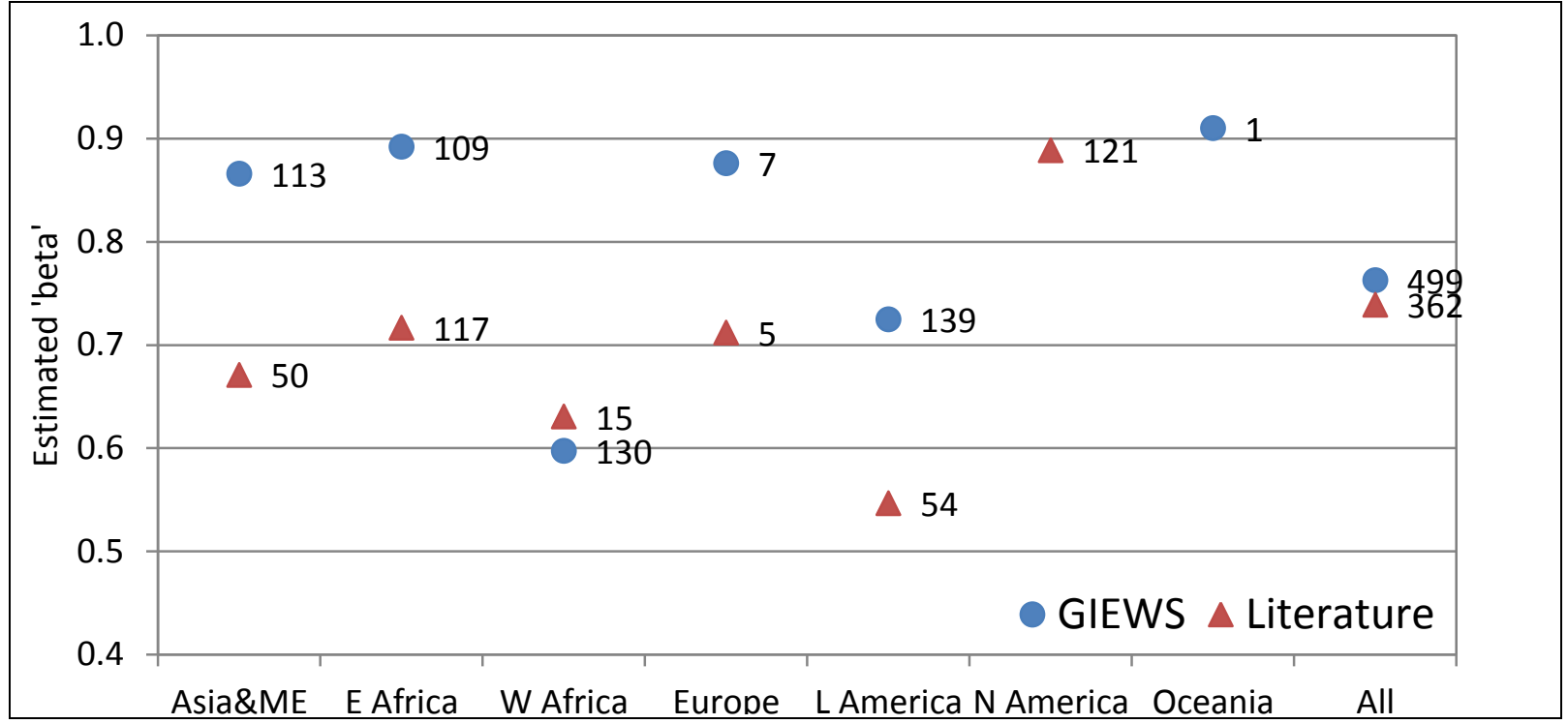

Note: Numbers indicate the number of observations underlying each average.

Source: Own calculations with literature sample and GIEWS price data.

\subsubsection{Estimates of the adjustment parameter $(\alpha)$}

Table 5 present average estimates of the adjustment parameters $\alpha$ taken from the literature and GIEWS samples by product and region. We focus on the adjustment parameter from the first equation in (2) above, i.e. the equation that explains changes in domestic prices, because in the majority of all cases, only this $\alpha$ is statistically significant. In other words, the dynamics of international/domestic cereal PT are such that domestic prices adjust to deviations from the long-run price relationship, but international prices do not. The only notable exception to this rule is rice, to which we return below. As discussed above, the adjustment parameter from the first equation in (2) above is expected to be negative.

Figure $\mathbf{2 b}$ : Average estimates of the long-run price transmission coefficient $(\boldsymbol{\beta})$ by cereal

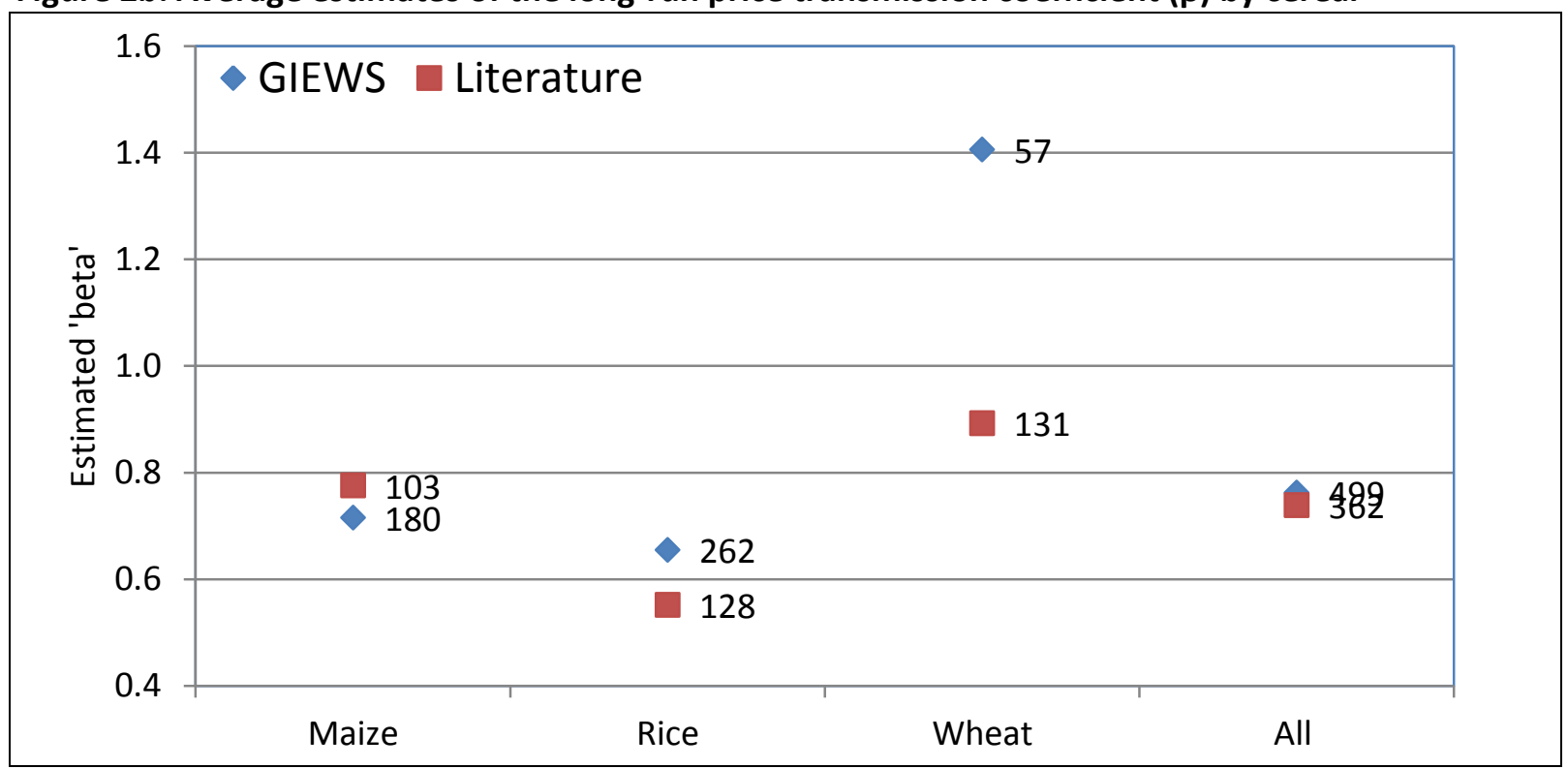

Note: Numbers indicate the number of observations underlying each average.

Source: Own calculations with literature sample and GIEWS price data. 
Table 5: Average estimates of the adjustment parameter $\alpha$ taken from the literature and GIEWS samples, by product and region

\begin{tabular}{l|c|c|c|c|c|c|c|c}
\hline & \multicolumn{2}{|c|}{ Maize } & \multicolumn{2}{c|}{ Rice } & \multicolumn{2}{c|}{ Wheat } & \multicolumn{2}{c}{ All three cereals } \\
\cline { 2 - 9 } & GIEWS & Lit. & GIEWS & Lit. & GIEWS & Lit. & GIEWS & Lit. \\
\hline Asia \& ME & -0.11 & 0.10 & -0.04 & -0.14 & -0.05 & -0.07 & -0.05 & -0.13 \\
E. Africa & -0.16 & 0.02 & -0.17 & 0.37 & -0.12 & -0.25 & -0.16 & 0.06 \\
W. Africa & -0.14 & -0.10 & -0.13 & -0.16 & -0.18 & - & -0.14 & -0.16 \\
Europe & -0.10 & -0.09 & -0.04 & -0.15 & -0.10 & -0.08 & -0.09 & -0.11 \\
L. America & -0.14 & - & -0.09 & -0.36 & -0.07 & -0.10 & -0.11 & -0.26 \\
N. America & - & - & - & - & - & -0.14 & - & -0.14 \\
Oceania & - & - & -0.10 & - & - & -0.08 & -0.10 & -0.08 \\
\hline All regions & -0.13 & -0.02 & -0.10 & -0.09 & -0.10 & -0.12 & -0.11 & -0.09 \\
\hline
\end{tabular}

Note: Averages by region and cereal weighted by the number of observations in each category. The expected sign of $\alpha$ is negative.

Source: Own calculations with literature sample and GIEWS price data.

The results presented in Table 5 and summarized by region and by cereal in Figures $3 \mathrm{a}$ and $3 \mathrm{~b}$, respectively, point to relatively slow PT for most cereal products and regions, irrespective of whether literature averages or averages based on own estimates with GIEWS price data are considered. The average $\alpha$ estimated using GIEWS data is slightly larger in magnitude than the average in the literature $(-0.11$ as opposed to -0.09$)$ but both indicate a relatively slow rate of PT whereby roughly $10 \%$ of any deviation from the long-run equilibrium relationship between international and domestic prices is corrected in the course of one month. This implies that it will take between 6 and 7 months to correct one-half of any disequilibrium that emerges due to unexpected price movements on international or domestic markets.

Somewhat more rapid responses are indicated by the GIEWS averages across all cereals for East and West Africa (average $\alpha=-0.16$ and -0.14 , which correspond to a half-lives of 4 and 5 months) and in particular by the literature estimates for Latin America (average $\alpha=-0.26$, corresponding to a half-life of somewhat more than 2 months). However, the literature also produces positive average estimates of $\alpha$ for maize in Asia and the Middle East as well as for rice in East Africa. This is counterintuitive, because it suggests that deviations from the long-run equilibrium are not corrected but rather amplified, which would drive domestic and international prices apart over time. However, the average of $\alpha=0.10$ for maize in Asia and the Middle East is based on only one observation, and the average of $\alpha=0.37$ for rice in East is based on only 15 observations. Finally, viewed by product the only obvious discrepancy is that the average literature estimates of $\alpha$ for maize are considerably lower $(=-0.02)$ than all other averages (Figure 3b). 99 of the 103 observations that underlie this average are from East Africa, which also explains why the average literature-based estimates of $\alpha$ for East Africa as a whole are so low (compare Table 5 and Figure 3a). If only those product/country combinations for which there are observations in both the GIEWS and the literature samples are included in the comparison (see Appendix Table 4), the results point to slightly slower PT on average in the GIEWS sample (average $\alpha=-0.09$ rather than the -0.11 above), but considerably more rapid PT on average in the literature sample (average $\alpha=-0.17$ rather than the -0.09 above). 
Figure 3a: Average estimates of the short-run price transmission coefficient $(\alpha)$ by region

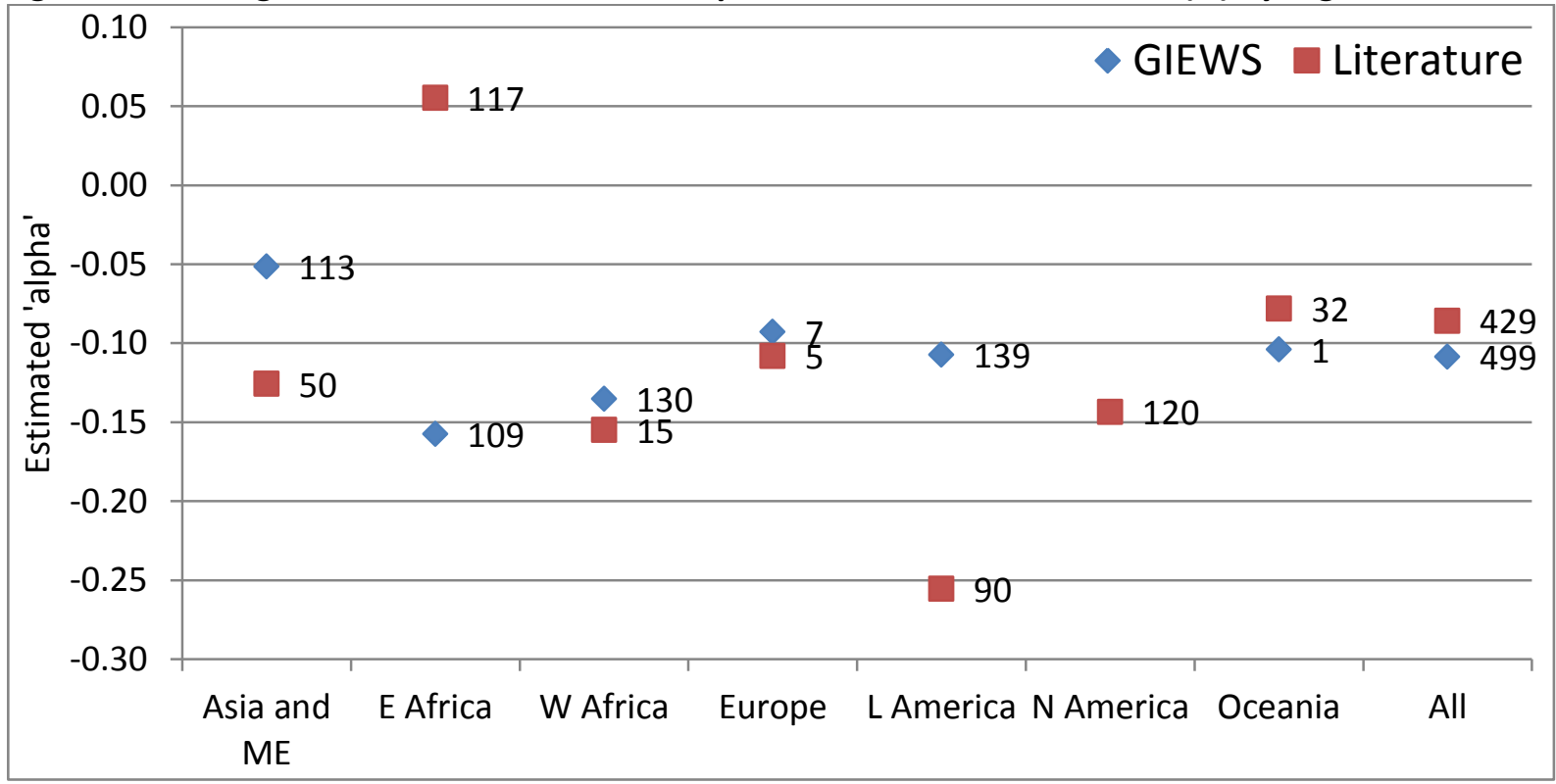

Note: Numbers indicate the number of observations underlying each average.

Source: Own calculations with literature sample and GIEWS price data.

If the adjustment parameters from the second equation in (2) above are considered, we see that these are generally insignificant, except for rice (Appendix Table 6). Specifically, there is evidence of a statistically significant reaction by international prices to disequilibrium between domestic and international prices in 121 market pairs (24\%), of which 111 involve rice. Roughly $40 \%$ of all rice prices are affected, and in most cases the adjustment parameter in question has the appropriate (positive) sign. These pairs involve many countries and are not confined to a few 'large' countries such as China or India. As pointed out above, the simple linear VECM is restrictive and probably not appropriate for many of the individual price pairs in the GIEWS data. Hence, a certain number of spuriously significant adjustment parameters for international prices can be expected. Nevertheless, the fact that significant adjustment parameters for international prices occur, if at all, almost exclusively for rice price pairs suggests that the determination of international rice prices differs fundamentally from the determination of international wheat and maize prices. These results confirm a very similar finding by Gilbert (2011). We can conclude that most countries are price takers on wheat and maize markets, but the evidence for rice is mixed. 
Figure 3b: Average estimates of the short-run price transmission coefficient $(\alpha)$ by cereal

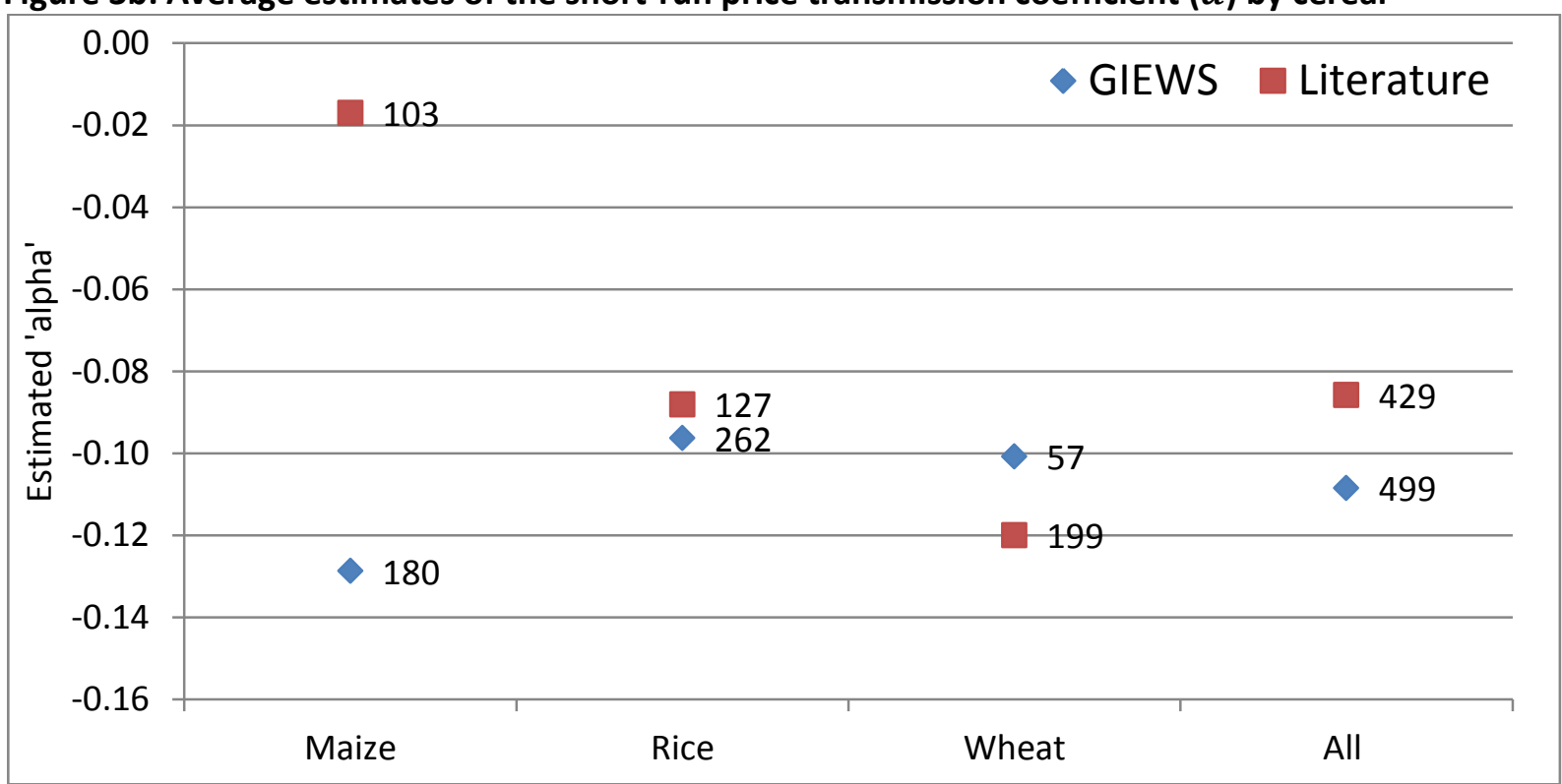

Note: Numbers indicate the number of observations underlying each average.

Source: Own calculations with literature sample and GIEWS price data.

\subsubsection{Before and after July 2007}

Table 6 contrasts median estimates of the coefficient of PT on cereal markets before and after the onset of the recent phase of price peaks and increased price volatility in mid-2007. If we compare the median estimates from the period prior to July 2007 with the median estimates from the period thereafter, no clear pattern emerges. On maize markets the long-run PT coefficients $(\beta)$ have fallen considerably since mid-2007, from 0.385 to 0.116 or from 0.438 to 0.103 depending on whether all price pairs or only cointegrated price pairs are considered. On rice and wheat markets the results Are ambiguous. If we consider only the international/domestic price pairs that are cointegrated, the median long-run PT coefficients have increased, from 0.547 to 0.705 for rice and from 0.576 to 1.013 for wheat. However, at the same time the short-run adjustment coefficients $(\alpha)$ have fallen, from 0.201 to 0.140 for rice and from 0.683 to 0.212 for wheat. This suggests that PT has become more complete but slower since mid-2007 for rice and wheat. However, these results must be interpreted with caution. We have used the median rather than the mean because the median is more robust vis-à-vis outliers (for example, implausibly large estimates of $\beta$ for some international/domestic price pairs). The prevalence of such outliers is nevertheless high in particular in the post-July 2007 VECM results, presumably due to the short length of the available time series.

Table 6: Median price transmission parameters estimated with GIEWS data before and after July 2007 (only for international/domestic price pairs that are cointegrated)

\begin{tabular}{l|cc|cc|cc}
\hline \multirow{2}{*}{ Time period } & \multicolumn{2}{c|}{ Maize } & \multicolumn{2}{c|}{ Rice } & \multicolumn{2}{c}{ Wheat } \\
\cline { 2 - 7 } & $\boldsymbol{\alpha}$ & $\boldsymbol{\beta}$ & $\boldsymbol{\alpha}$ & $\boldsymbol{\beta}$ & $\boldsymbol{\alpha}$ & $\boldsymbol{\beta}$ \\
\hline \multicolumn{8}{c}{ All international/domestic price pairs } \\
\hline Before July 2007 & -0.192 & 0.385 & -0.204 & 0.623 & -0.136 & 1.208 \\
After July 2007 & -0.221 & 0.116 & -0.053 & 0.553 & -0.143 & 0.463 \\
\hline \multicolumn{8}{c}{ Only cointegrated international/domestic price pairs } \\
\hline Before July 2007 & -0.216 & 0.438 & -0.201 & 0.547 & -0.683 & 0.576 \\
After July 2007 & -0.308 & 0.103 & -0.140 & 0.705 & -0.212 & 1.013 \\
\hline
\end{tabular}

Source: Own calculations with GIEWS price data. 


\section{Analysis of the determinants of the strength of price transmission}

\subsection{Method}

The averages presented above hide considerable variation in the literature-based and GIEWS-based estimates of $\alpha$ and $\beta$ for individual country/product combinations. To explain this variation, and thus to generate insights into the factors that influence the strength of PT from international to domestic markets, we estimate meta-regressions. In each regression a set of estimated parameters ( $\alpha^{\prime} s$ or $\beta^{\prime} s$ ) from the literature or from GIEWS is regressed on a set of covariates that might be expected to influence PT. These covariates are listed and described in Table 7 and cover geographic (e.g. landlocked), infrastructural (e.g. logistics), institutional (e.g. STE) and market or commodity specific factors (e.g. net importer). We include dummy variables for cereals (omitting rice) and regions (omitting Asia/Pacific) to capture any corresponding fixed effects.

\subsection{Results}

We first present the results of logit regressions that predict whether pairs of international and domestic prices are cointegrated. The dependent variable equals 1 when the two prices are cointegrated, and 0 otherwise, and this variable is explained using the covariates listed in Table 7 for example whether the country in question is landlocked, whether it has an STE for cereals, etc.

Table 7: Covariates used in the meta-analysis of the determinants of price transmission

\begin{tabular}{|c|c|c|c|}
\hline Name & Description & Source / link & Expectation / theory \\
\hline $\begin{array}{l}\text { Commodity } \\
\text { fixed effects }\end{array}$ & Wheat, maize, rice & & $\begin{array}{l}\text { Unobserved commodity- } \\
\text { specific heterogeneity }\end{array}$ \\
\hline $\begin{array}{l}\text { Region fixed } \\
\text { effects }\end{array}$ & $\begin{array}{l}\text { Europe; East and South Africa; } \\
\text { West and Central Africa; MENA } \\
\text { and Asia; Oceania; Latin America }\end{array}$ & $\begin{array}{l}\text { http://unstats.un.org } \\
\text { Lunsd/methods/m49 } \\
\text { Lm49regin.htm }\end{array}$ & $\begin{array}{l}\text { Unobserved region-specific } \\
\text { heterogeneity }\end{array}$ \\
\hline Landlocked & 1 if country has no access to sea & Google maps & $\begin{array}{l}\text { For landlocked countries, } \\
\text { international trade must cross } \\
\text { more borders }\end{array}$ \\
\hline $\begin{array}{l}\text { Trade } \\
\text { openness }\end{array}$ & $\begin{array}{l}\text { Total trade as a share of income, } \\
\text { average 2006-2010 (Import + } \\
\text { Export /GDP) }\end{array}$ & $\begin{array}{l}\text { World Bank } \\
\text { Development } \\
\text { Indicators }\end{array}$ & $\begin{array}{l}\text { Open economies are better } \\
\text { integrated into world markets } \\
\text { and thus PT should be stronger }\end{array}$ \\
\hline STE & $\begin{array}{l}1 \text { for countries that have state } \\
\text { trading enterprises (STEs) }\end{array}$ & Literature* & $\begin{array}{l}\text { STEs interfere with trade and } \\
\text { insulate the domestic prices } \\
\text { from international fluctuations }\end{array}$ \\
\hline $\begin{array}{l}\text { Ease of } \\
\text { trade }\end{array}$ & $\begin{array}{l}\text { Ease of trading across borders, } \\
\text { between } 0 \text { (worst) to } 1 \text { (best) }\end{array}$ & $\begin{array}{l}\text { World Bank, Doing } \\
\text { Business, Ease of } \\
\text { Trading across } \\
\text { borders. }\end{array}$ & Transaction costs reduce PT \\
\hline Logistics & $\begin{array}{l}\text { Logistics performance index of } \\
\text { quality of trade and transport- } \\
\text { related infrastructure between } 1 \\
\text { (worst) to } 5 \text { (best) }\end{array}$ & World Bank 2007 & $\begin{array}{l}\text { Better logistics mean lower } \\
\text { costs of trade and higher PT }\end{array}$ \\
\hline $\begin{array}{l}\text { Net } \\
\text { importer }\end{array}$ & $\begin{array}{l}\text { Net cereal import ratio (export - } \\
\text { import, } 3 \text { year average 2009- } \\
2011 \text { ) to domestic consumption }\end{array}$ & USDA, PSD Online & $\begin{array}{l}\text { If the share of staple imports in } \\
\text { domestic consumption is high, } \\
\text { more is undertaken to insulate } \\
\text { domestic markets }\end{array}$ \\
\hline Retail & $\begin{array}{l}1 \text { if domestic price is measured at } \\
\text { the retail rather than a more } \\
\text { upstream level }\end{array}$ & Literature / GIEWS & $\begin{array}{l}\text { The farther 'inland' a domestic } \\
\text { price is measured, the weaker } \\
\text { its link to international prices }\end{array}$ \\
\hline
\end{tabular}

Note: * See Appendix Table 5 for a list of the countries with STEs. 
The results for the literature estimates in the first column of Table 8 indicate that wheat markets have an almost $50 \%$ higher probability of being cointegrated than rice or maize markets, and that West African prices have a roughly $14 \%$ lower probability of being cointegrated with international prices than prices in the default region, Asia. A high net import ratio for a product reduces the probability of cointegration with international prices by $31 \%$; a high import ratio may lead to more policy intervention to insulate domestic markets from international price movements. If an STE is responsible for trading the product in question, the probability of cointegration increases by roughly $11 \%$, and if the domestic price being considered is a retail price, the probability that it is cointegrated with international prices falls by almost $30 \%$. The former result is puzzling but the latter is plausible, as retail prices are further removed from international prices than wholesale or border prices.

The logit results for the GIEWS sample in Table 8 also indicate that retail prices are less likely to be cointegrated with international prices, but otherwise they differ in several respects from the logit results for the literature sample. Maize and wheat are less likely to be cointegrated with the corresponding international prices than rice prices are (by roughly 30 and $20 \%$, respectively), and domestic prices in East Africa, West Africa and Latin America are more likely to be cointegrated with international prices (by 25, 32 and 19\%, respectively). If an STE is in place, the probability of cointegration falls by almost $22 \%$. Improvements in logistics have a surprising negative impact on the probability of cointegration between domestic and international prices. Ease of trade has the expected positive impact, and being landlocked the expected negative impact on the probability of cointegration, but neither of these effects is significant. Most of these results also hold if only the time period after July 2007 is considered. However, if the period prior to July 2007 is considered the logit regression is much less informative. This is probably due to the fact that many GIEWS price series are very short prior to July 2007, leaving too few observations for dependable cointegration testing. Hence, the logit regression for the pre-July 2007 period is based on fewer and less trustworthy test results.

Table 8: Logit regression of cointegration status on factors that might influence price transmission (marginal effects rather than coefficient estimates are reported)

\begin{tabular}{|c|c|c|c|c|c|c|c|}
\hline \multirow{2}{*}{$\begin{array}{l}\text { Covariate } \\
\text { Maize }\end{array}$} & \multicolumn{2}{|c|}{ Literature } & \multicolumn{2}{|c|}{ GIEWS entire period } & \multirow{2}{*}{$\begin{array}{c}\begin{array}{c}\text { GIEWS before } \\
\text { July } 2007\end{array} \\
0.044\end{array}$} & \multicolumn{2}{|c|}{$\begin{array}{l}\text { GIEWS after } \\
\text { July } 2007\end{array}$} \\
\hline & 0.050 & & -0.296 & $* * *$ & & -0.269 & $* * *$ \\
\hline Wheat & 0.476 & $* * *$ & -0.202 & $* * *$ & -0.151 & -0.130 & * \\
\hline East Africa & -0.146 & & 0.251 & $* *$ & 0.091 & 0.310 & $* * *$ \\
\hline West Africa & -0.136 & * & 0.321 & $* * *$ & 0.093 & 0.388 & $* * *$ \\
\hline Europe & . & & 0.189 & & $-0.175 * * *$ & 0.163 & \\
\hline Latin America & -0.049 & & 0.189 & $* *$ & -0.041 & 0.286 & $* * *$ \\
\hline Trade openness & -0.001 & & 0.000 & & 0.002 & 0.000 & \\
\hline Net importer & -0.312 & $* * *$ & 0.035 & & 0.033 & 0.136 & \\
\hline STE & 0.107 & $* *$ & -0.216 & $* * *$ & 0.283 & 0.009 & \\
\hline Retail & -0.291 & $* * *$ & -0.126 & $* *$ & 0.064 & -0.127 & $* *$ \\
\hline Ease of trade & 0.437 & & 0.395 & & 0.245 & 0.509 & \\
\hline Logistics & 0.027 & & -0.527 & $* * *$ & -0.152 & -0.460 & $* * *$ \\
\hline Landlocked & 0.051 & & -0.125 & & -0.074 & 0.119 & \\
\hline
\end{tabular}

Note: The literature sample includes too few observations for Europe to permit estimation. ${ }^{*}, * *$ and ${ }^{* * *}$ refer to significance at the $10 \%, 5 \%$ and $1 \%$ levels, respectively.

Meta-regression results for individual estimates of $\alpha$ and $\beta$ are summarized in Tables 9,10 and 11 . Table 9 presents results for all of the estimates of $\alpha$ and $\beta$ derived from the literature sample, and for the GIEWS estimates of $\alpha$ and $\beta$ from all domestic/international price pairs. Table 10 again presents results for all of the estimates of $\alpha$ and $\beta$ derived from the literature sample. However, in Table 10 the Heckman procedure is used to generate results for the literature sample that are conditional on 
cointegration. Moreover, in Table 10 the GIEWS estimates are based only on $\alpha$ and $\beta$ from cointegrated domestic/international price pairs. Finally, Table 11 presents only GIEWS-based estimates, in this case only for estimates of $\alpha$ and $\beta$ from non-cointegrated domestic/international price pairs.

Table 9: Estimated coefficients for the meta-regressions (GIEWS results based on estimates of $\alpha$ and $\beta$ using all international/domestic price pairs)

\begin{tabular}{|c|c|c|c|c|c|c|c|c|}
\hline \multirow{2}{*}{ Covariate } & \multicolumn{2}{|c|}{ Literature } & \multicolumn{2}{|c|}{ GIEWS entire period } & \multicolumn{2}{|c|}{ GIEWS before 07/2007 } & \multicolumn{2}{|c|}{ GIEWS after 07/2007 } \\
\hline & $\alpha$ & $\boldsymbol{\beta}$ & $\alpha$ & $\boldsymbol{\beta}$ & $\alpha$ & $\boldsymbol{\beta}$ & $\alpha$ & $\boldsymbol{\beta}$ \\
\hline Intercept & $0.782 * *$ & $3.869 *$ & $-0.323 * * *$ & -0.712 & 0.265 & -2.765 & -0.082 & 4.230 \\
\hline Maize & 0.066 & 0.163 & $-0.067 * * *$ & 0.131 & -0.033 & -0.046 & $-0.137 * * *$ & 0.719 \\
\hline Wheat & 0.077 & $0.363^{*}$ & 0.002 & $0.491 * *$ & -0.025 & $5.088^{* *}$ & $-0.112 * * *$ & $5.091 * * *$ \\
\hline East Africa & $0.448 * * *$ & -0.331 & -0.013 & 0.148 & $-0.339 * * *$ & 2.360 & 0.004 & 3.164 \\
\hline West Africa & 0.052 & $0.751^{*}$ & $-0.051^{*}$ & 0.148 & $-0.408 * * *$ & 2.216 & $-0.149 * * *$ & 2.648 \\
\hline Europe & - & - & 0.038 & 0.644 & -0.050 & -0.033 & 0.025 & 3.108 \\
\hline Latin America & $-0.156^{* * *}$ & $-0.407 *$ & 0.008 & 0.252 & $-0.356 * * *$ & 2.275 & -0.005 & $3.722 * *$ \\
\hline Trade openness & 0.000 & 0.004 & 0.000 & 0.000 & $-0.004 * * *$ & $0.077^{* *}$ & 0.000 & -0.008 \\
\hline Net importer & $0.060 *$ & $0.401^{*}$ & $0.054 * *$ & -0.227 & 0.014 & 0.102 & -0.004 & 0.362 \\
\hline STE & -0.090 & -0.144 & 0.031 & $0.390^{*}$ & $-0.244 * * *$ & -3.216 & 0.019 & -1.115 \\
\hline Retail & 0.001 & -0.437 & 0.002 & 0.197 & -0.025 & -2.418 & -0.020 & 1.095 \\
\hline Ease of trade & $-1.414^{* *}$ & $-5.383^{*}$ & -0.035 & 1.303 & 0.197 & -7.242 & -0.173 & 9.935 \\
\hline Logistics & 0.015 & -0.022 & $0.094 * * *$ & -0.013 & -0.023 & 0.878 & 0.054 & $-6.168 * * *$ \\
\hline Landlocked & $-0.736 * * *$ & -0.562 & 0.023 & $0.447^{*}$ & -0.076 & -1.765 & 0.048 & 0.316 \\
\hline $\mathbf{R}^{2}$ & 0.424 & 0.524 & 0.170 & 0.041 & 0.225 & 0.052 & 0.210 & 0.072 \\
\hline
\end{tabular}

Note: All meta-regressions estimated using OLS. The literature sample includes too few observations for Europe to permit estimation. ${ }^{*},{ }^{* *}$ and ${ }^{* * *}$ refer to significance at the $10 \%, 5 \%$ and $1 \%$ levels, respectively.

Table 10: Estimated coefficients for the meta-regressions (GIEWS results based on estimates of $\alpha$ and $\beta$ only from cointegrated international/domestic price pairs)

\begin{tabular}{l|cc|cc|cc|cc}
\hline \multirow{2}{*}{ Covariate } & \multicolumn{2}{|c|}{$\begin{array}{c}\text { Literature (Heckman } \\
\text { procedure) }\end{array}$} & \multicolumn{2}{c|}{ GIEWS entire period } & \multicolumn{2}{c|}{ GIEWS before $\mathbf{0 7 / 2 0 0 7}$} & \multicolumn{2}{c}{ GIEWS after 07/2007 } \\
\cline { 2 - 9 } & $\boldsymbol{\alpha}$ & $\boldsymbol{\beta}$ & $\boldsymbol{\alpha}$ & $\boldsymbol{\beta}$ & $\boldsymbol{\alpha}$ & $\boldsymbol{\beta}$ & $\boldsymbol{\alpha}$ & $\boldsymbol{\beta}$ \\
\hline Intercept & $0.720^{* *}$ & $4.834^{* *}$ & $-0.262^{*}$ & 0.725 & 0.718 & -0.504 & 0.045 & -5.871 \\
Maize & 0.035 & 0.187 & $-0.069^{* *}$ & 0.057 & -0.068 & 0.009 & $-0.167^{* * *}$ & -1.441 \\
Wheat & $0.139^{* *}$ & 0.218 & 0.034 & 0.146 & -0.591 & 0.279 & $-0.170^{* *}$ & $8.762^{* *}$ \\
East Africa & $0.446^{* * *}$ & -0.298 & -0.033 & -0.017 & $-0.778^{* * *}$ & -0.178 & -0.041 & 5.596 \\
West Africa & 0.087 & $0.790^{*}$ & -0.031 & -0.008 & $-0.977^{* * *}$ & 0.024 & $-0.184^{* *}$ & 3.069 \\
Europe & - & - & 0.078 & 0.393 & - & - & 0.130 & 5.941 \\
Latin America & $-0.130^{* *}$ & $-0.460^{*}$ & -0.015 & 0.142 & $-1.043^{* * *}$ & 0.300 & -0.023 & 4.023 \\
Trade openness & 0.001 & 0.005 & 0.000 & 0.001 & $-0.008^{* * *}$ & 0.004 & 0.000 & 0.000 \\
Net importer & 0.021 & $0.666^{* *}$ & 0.053 & -0.160 & 0.278 & $-0.900 *$ & -0.005 & 0.720 \\
STE & -0.060 & -0.117 & -0.023 & 0.141 & $-0.826^{* * *}$ & -0.038 & 0.043 & -2.963 \\
Retail & -0.084 & -0.268 & -0.020 & 0.004 & 0.008 & -0.094 & -0.054 & 1.546 \\
Ease of trade & $-1.498^{* *}$ & $-6.490^{*}$ & 0.118 & 0.433 & 0.882 & -0.826 & 0.148 & 3.976 \\
Logistics & 0.037 & -0.125 & 0.038 & -0.282 & -0.006 & 0.504 & -0.113 & -0.152 \\
Landlocked & $-0.711^{* * *}$ & -0.865 & 0.008 & 0.156 & -0.089 & 0.211 & $0.143^{* *}$ & 1.633 \\
\hline $\mathbf{R}^{\mathbf{2}}$ & 0.435 & 0.538 & 0.101 & 0.032 & 0.489 & 0.212 & 0.265 & 0.119 \\
\hline
\end{tabular}

Note: Meta-regression with literature data estimated using Heckman procedure. The literature sample and the GIEWS sample before July 2007 includes too few observations for Europe to permit estimation. * ** and *** refer to significance at the $10 \%, 5 \%$ and $1 \%$ levels, respectively.

Consider first the meta-regressions based on estimates of $\alpha$ and $\beta$ derived from the literature. We see first that the results in the first column of Table 9 (estimated with OLS) are very similar to the results in the first column of Table 10 (estimated with the Heckman procedure). This suggests that estimating these meta-regressions conditional on cointegration does not have a significant impact on 
the results. ${ }^{10}$ Similarly, the GIEWS-based meta-regressions in Table 9, which are based on all estimates of $\alpha$ and $\beta$, are generally quite similar to the corresponding GIEWS-based meta-regressions in Table 10, which are based only on estimates of $\alpha$ and $\beta$ from cointegrated domestic/international price pairs. For example, in both tables we see in the second column that $\alpha$ is roughly 7 percentage points more negative for maize prices than for rice and wheat prices, suggesting that PT on maize markets is somewhat more rapid. This supports the finding in Table 5 and Figure $3 b$ that $\alpha$ 's for maize tend to be somewhat larger (in magnitude). Indeed, this result is also corroborated by the results in Table 11 which are based only on non-cointegrated price pairs. Here the estimated coefficient for maize indicates that $\alpha$ is roughly 8 percentage points more negative for maize prices.

Similar parallels can be found across all three tables for example for the West Africa fixed effect (-5.1 percentage points in Table 9, -3.1 percentage points in Table 10, and -7.7 percentage points in Table 11) and for the ratio of net imports to consumption (5.4, 5.3 and 5.8 percentage points less error correction according to the results in Tables 9, 10 and 11, respectively). Some parallel findings are counter-intuitive, however. In particular, in both Table 9 and Table 11 we see that improvements in logistics are associated with large (less negative) values of $\alpha$, and therefore with slower PT.

Table 11: Estimated coefficients for the meta-regressions (GIEWS results based on estimates of $\alpha$ and $\beta$ only from non-cointegrated international/domestic price pairs)

\begin{tabular}{|c|c|c|c|c|c|c|}
\hline \multirow{2}{*}{ Covariate } & \multicolumn{2}{|c|}{ GIEWS entire period } & \multicolumn{2}{|c|}{ GIEWS before $07 / 2007$} & \multicolumn{2}{|c|}{ GIEWS after 07/2007 } \\
\hline & $\alpha$ & $\boldsymbol{\beta}$ & $\alpha$ & $\boldsymbol{\beta}$ & $\alpha$ & $\boldsymbol{\beta}$ \\
\hline Intercept & $-0.315^{* * *}$ & -1.893 & 0.285 & -5.128 & -0.021 & 6.038 \\
\hline Maize & $-0.083^{* * *}$ & 0.200 & -0.036 & 0.406 & $-0.150 * * *$ & 1.342 \\
\hline Wheat & -0.007 & $0.639 *$ & 0.009 & $7.028 * *$ & $-0.115^{* * *}$ & $4.451^{*}$ \\
\hline East Africa & 0.001 & 0.250 & $-0.253 * * *$ & 4.144 & 0.038 & 2.742 \\
\hline West Africa & $-0.077 * *$ & 0.161 & $-0.348 * * *$ & 3.155 & $-0.105^{* * *}$ & 2.651 \\
\hline Europe & 0.016 & 0.807 & 0.016 & 0.122 & -0.001 & 3.242 \\
\hline Latin America & 0.029 & 0.263 & $-0.211 * * *$ & 3.624 & 0.013 & $4.422 *$ \\
\hline Trade openness & $0.001 * *$ & -0.002 & $-0.002 * * *$ & $0.093 * *$ & 0.000 & -0.006 \\
\hline Net importer & $0.058 *$ & -0.187 & -0.012 & 0.311 & -0.015 & 0.592 \\
\hline STE & $0.043^{*}$ & 0.431 & $-0.130 * * *$ & $-5.846^{*}$ & 0.020 & -0.318 \\
\hline Retail & 0.007 & 0.362 & -0.039 & -3.046 & -0.012 & 0.636 \\
\hline Ease of trade & -0.194 & 2.220 & -0.149 & -12.210 & $-0.347 * *$ & 12.656 \\
\hline Logistics & $0.120 * * *$ & 0.191 & -0.032 & 2.257 & 0.073 & $-7.854 * * *$ \\
\hline Landlocked & 0.010 & 0.629 & -0.082 & -2.150 & 0.008 & -1.625 \\
\hline $\mathbf{R}^{2}$ & 0.239 & 0.059 & 0.222 & 0.080 & 0.293 & 0.075 \\
\hline
\end{tabular}

Note: The literature sample and the GIEWS sample before July 2007 includes too few observations for Europe to permit estimation. *, ** and ${ }^{* * *}$ refer to significance at the $10 \%, 5 \%$ and $1 \%$ levels, respectively.

Moving to the GIEWS-based results for the pre-July 2007 period, we again see many parallels between Tables 9, 10 and 11. In particular, all three tables display evidence of significantly more negative $\alpha$ 's (and therefore more rapid PT) for East and West Africa, for Latin America, for more trade open countries and, surprisingly, for countries with STEs. In the post-July 2007 period, the results in all three tables point to significantly more negative $\alpha$ 's for maize and wheat, and for West Africa.

These parallels are less apparent for the meta-regressions in Tables 9, 10 and 11 that explain the variation in the $\beta^{\prime}$ s. Overall, the meta-regressions indicate that the selected covariates are able to explain a larger proportion of the variance in the adjustment parameters (the $\alpha^{\prime} s$ ) than of the variance in the long-run price transmission coefficients (the $\beta^{\prime} s$ ). The meta-regressions for the GIEWS-based estimates of $\beta$ generally produce fewer significant coefficients, and they also produce many coefficients that are implausibly large, especially in the pre- and post-July 2007 subsamples.

\footnotetext{
${ }^{10}$ This conclusion is supported by the fact that the inverse Mills Ratio is only significant at the $10 \%$ level in the equation for $\alpha$ in Table 10, and not significant in the equation for $\beta$.
} 
Since $\beta$ is expected to be close to 1 , it is difficult for example to interpret coefficients that suggest that $\beta$ increases by over 7 for price pairs involving wheat, or falls by almost 6 in the presence of an STE (see the second column of Table 11).

In summary, the meta-regressions for the $\alpha$ 's do generate a few signals. In particular, there is strong evidence of more rapid PT for maize across all of the GIEWS results regardless of what period is considered and whether cointegrated and/or non-cointegrated results are considered. Similarly, evidence of more rapid PT in Latin America appears repeatedly in Tables 9 through 11. There is weaker evidence for a positive relationship between trade openness and the speed of PT, and a negative relationship between net import ratios and PT. Before July 2007 it appears that PT was stronger in the presence of STEs, and when estimation is carried out without allowance for a break in July 2007, it appears that better logistics are associated with slower PT. These last two results run counter to our a priori expectations. The meta-regressions for the $\beta$ 's have lower explanatory power than those for the $\alpha^{\prime} s$, and they fail to produce many robust and plausible results. ${ }^{11}$

\section{Analysis of agreement in the direction of domestic and international price movements}

The analysis presented in section 4 above is based on the assumption that PT is characterized by the specific parametric structure embodied in the VECM. The VECM is a popular and powerful model, but it might be too restrictive in present setting. For example, the VECM assumes that a domestic price will adjust by a fixed proportion of any given change in the international price, regardless of the magnitude of this change. To relax this assumption, we next study whether domestic prices and international prices simply move in the same directions in most periods, regardless of the magnitudes of these movements. If domestic and international prices tend to move in the same directions, then producers and consumers are at least confronted with appropriate qualitative price signals.

Table 12 first presents results for monthly price changes by region and by cereal, and Figures $4 a$ and $4 \mathrm{~b}$ provide corresponding visual summaries by region and cereal. Table 13 and Figures $5 \mathrm{a}$ and $5 \mathrm{~b}$ present corresponding results for lagged monthly price changes (international price change in month $t$ compared with the domestic price change in month $t+1$ ); Table 14 and Figures $6 \mathrm{a}$ and $6 \mathrm{~b}$ present the results for quarterly price changes; and Table 15 and Figures $7 \mathrm{a}$ and $7 \mathrm{~b}$ for annual price changes.

\footnotetext{
${ }^{11}$ We also experimented with weighted meta-regressions that account for the fact that some studies provide more observations to the literature sample than others, and that some countries are more prevalent in the GIEWS data than others. These meta-regressions did not generate any additional insights.
} 
Table 12: The direction of monthly price movements on domestic and international markets agreement and disagreement by region and cereal

\begin{tabular}{|c|c|c|c|c|c|c|}
\hline & $\begin{array}{c}\text { Agree: } \\
\Delta \mathrm{pw}<0 \\
\& \\
\Delta \mathrm{pd}<0\end{array}$ & $\begin{array}{c}\text { Agree: } \\
\Delta \mathrm{pw}>0 \\
\& \\
\Delta \mathrm{pd}>0\end{array}$ & $\begin{array}{c}\text { Disagree: } \\
\Delta \mathrm{pw}>0 \\
\& \\
\Delta \mathrm{pd}<0\end{array}$ & $\begin{array}{c}\text { Disagree: } \\
\Delta p w<0 \\
\& \\
\Delta p d>0\end{array}$ & $\begin{array}{l}\text { Sum: } \\
\text { agree }\end{array}$ & $\begin{array}{c}\text { Sum: } \\
\text { disagree }\end{array}$ \\
\hline \multicolumn{7}{|c|}{ By region } \\
\hline Asia and ME & $23 \%$ & $30 \%$ & $21 \%$ & $26 \%$ & $53 \%$ & $47 \%$ \\
\hline E. Africa & $22 \%$ & $31 \%$ & $25 \%$ & $22 \%$ & $53 \%$ & $47 \%$ \\
\hline W. Africa & $21 \%$ & $33 \%$ & $23 \%$ & $22 \%$ & $54 \%$ & $46 \%$ \\
\hline Europe & $27 \%$ & $29 \%$ & $24 \%$ & $20 \%$ & $56 \%$ & $44 \%$ \\
\hline L. America & $19 \%$ & $33 \%$ & $23 \%$ & $26 \%$ & $51 \%$ & $49 \%$ \\
\hline \multicolumn{7}{|c|}{ By cereal } \\
\hline Maize & $20 \%$ & $32 \%$ & $25 \%$ & $23 \%$ & $52 \%$ & $48 \%$ \\
\hline White maize & $20 \%$ & $34 \%$ & $24 \%$ & $21 \%$ & $54 \%$ & $46 \%$ \\
\hline Rice & $24 \%$ & $30 \%$ & $22 \%$ & $25 \%$ & $54 \%$ & $46 \%$ \\
\hline Wheat & $24 \%$ & $30 \%$ & $22 \%$ & $25 \%$ & $53 \%$ & $47 \%$ \\
\hline \multicolumn{7}{|c|}{ All regions and cereals } \\
\hline Total & $22 \%$ & $32 \%$ & $23 \%$ & $23 \%$ & $54 \%$ & $46 \%$ \\
\hline
\end{tabular}

Source: Own calculations with GIEWS price data.

The results indicate that there is a slight preponderance of positive changes in international market prices over the time periods covered by the GIEWS data; international price increased in $55 \%$ of all months $(32 \%+23 \%$ in the last row of Table 12$)$, and decreased in $45 \%$ of all months. ${ }^{12}$ In $58 \%$ of the months in which international prices increased, domestic prices increased as well (32 of 55\%). However, domestic prices decreased in only $49 \%$ of the months in which international prices decreased, as well (22 of $45 \%$ ).

Figure 4a: The direction of monthly price movements on domestic and international markets agreement and disagreement by region

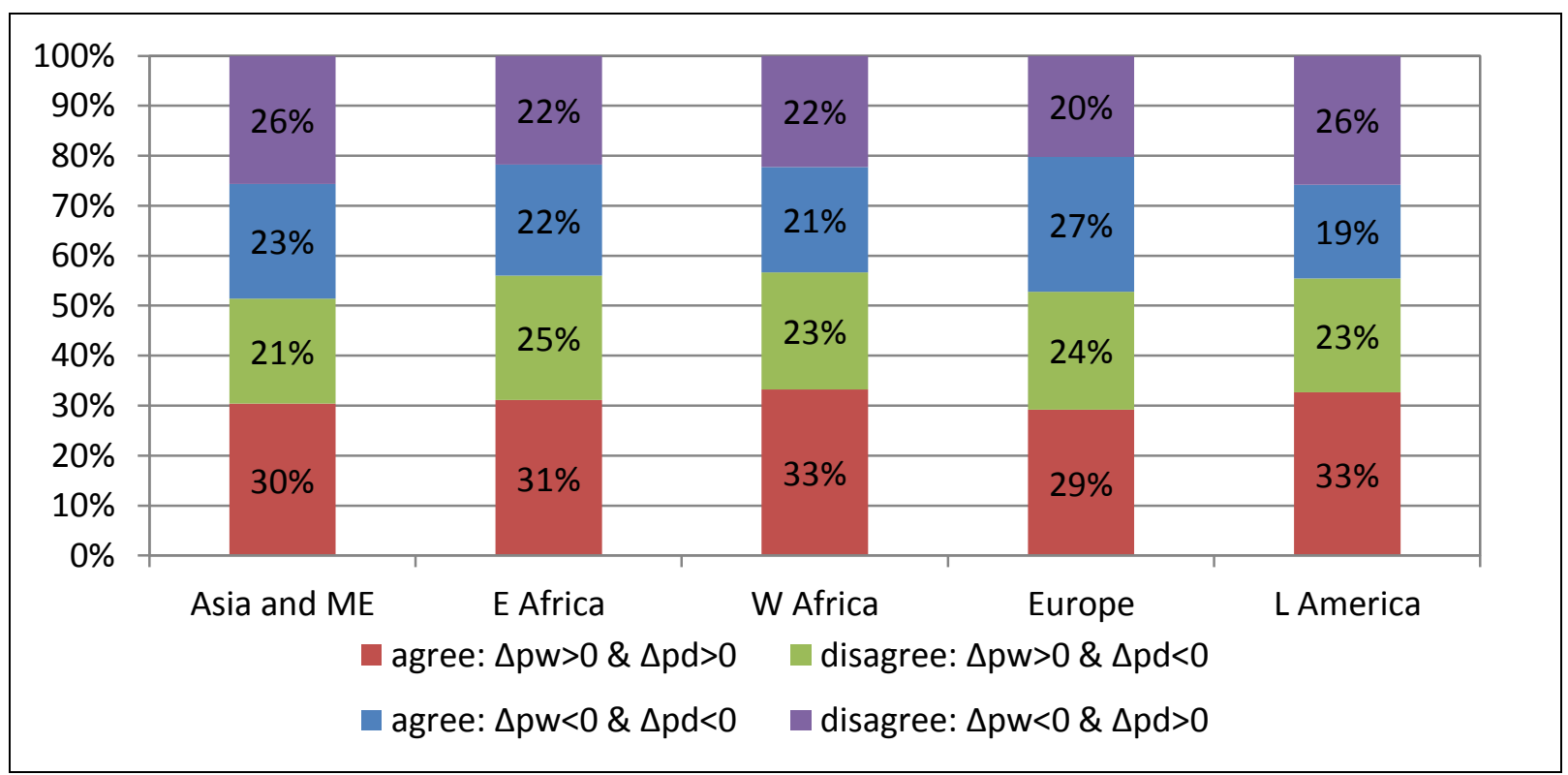

Source: Own calculations with GIEWS price data.

\footnotetext{
${ }^{12}$ Note that the share of months in which international prices increase is not the same over all regions or cereals because for each region and cereal different periods in which domestic prices overlap with international prices are available in the GIEWS data.
} 
Figure 4b: The direction of monthly price movements on domestic and international markets agreement and disagreement by cereal

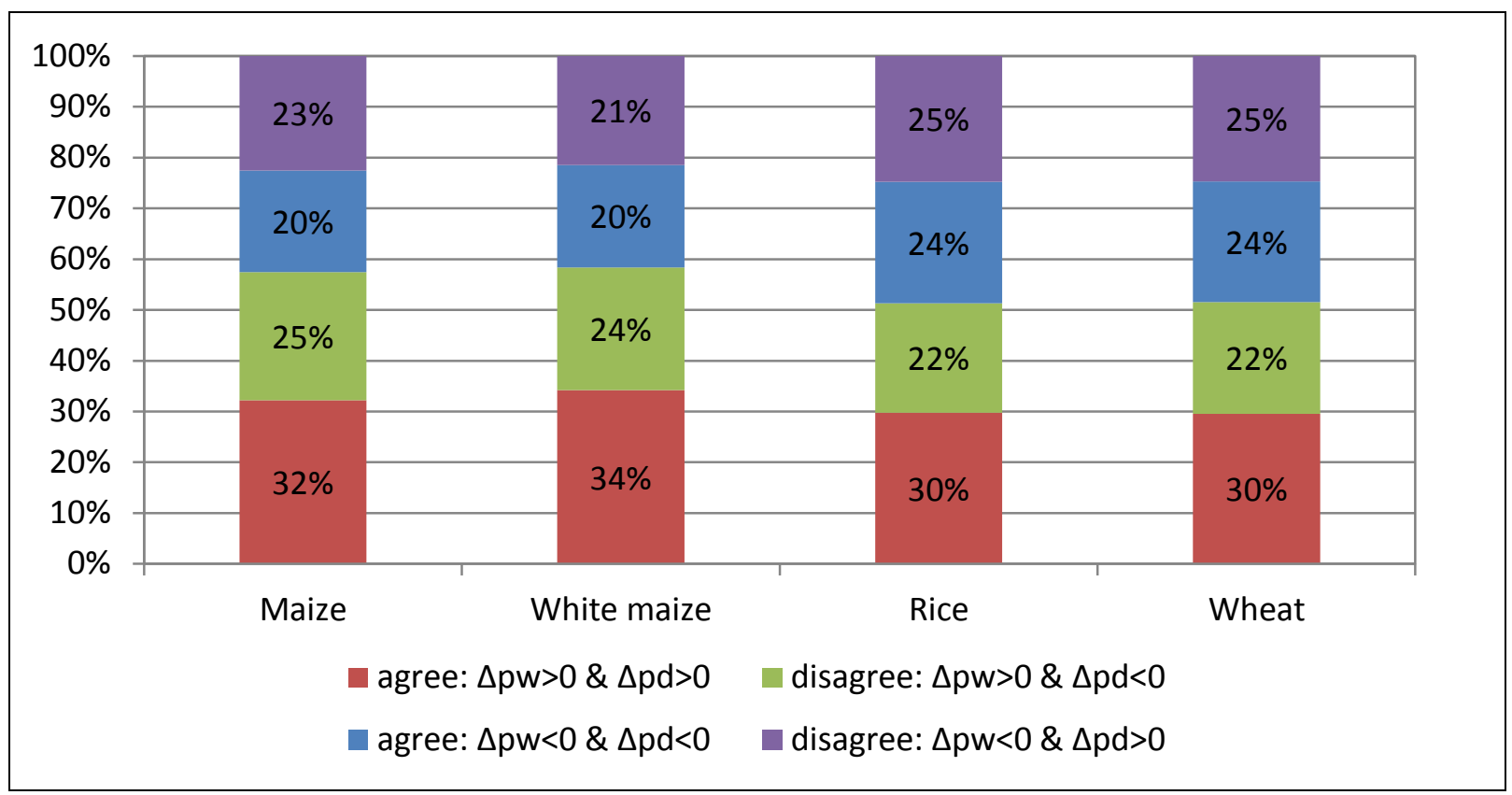

Source: Own calculations with GIEWS price data.

Overall, the agreement between the direction of price changes on international markets and on domestic markets is quite low, especially when international prices are falling. Table 12 and Figures $4 \mathrm{a}$ and $4 \mathrm{~b}$ show that this result holds quite uniformly across regions and products. The only slight exception is that prices in Europe tend to move in the same direction as international prices in a slightly higher proportion of all months (56\%), while prices in Latin America tend to move in the same direction somewhat less often (51\%). While falling international prices tend to be passed on to markets in Europe ( 27 of $47 \%$, or in $57 \%$ of all cases), this is not the case in Latin America, where falling international prices are only passed on in $42 \%$ of all cases ( 19 or $45 \%$ ).

Table 13: The direction of lagged monthly price movements on international (month $t$ ) and domestic (month $t+1$ ) markets - agreement and disagreement by region and cereal

\begin{tabular}{|c|c|c|c|c|c|c|}
\hline & $\begin{array}{c}\text { Agree: } \\
\Delta p w<0 \\
\& \\
\Delta p d<0\end{array}$ & $\begin{array}{c}\text { Agree: } \\
\Delta p w>0 \\
\& \\
\Delta p d>0\end{array}$ & $\begin{array}{c}\text { Disagree: } \\
\Delta p w>0 \\
\& \\
\Delta p d<0\end{array}$ & $\begin{array}{c}\text { Disagree: } \\
\Delta p w<0 \\
\& \\
\Delta p d>0\end{array}$ & $\begin{array}{l}\text { Sum: } \\
\text { agree }\end{array}$ & $\begin{array}{c}\text { Sum: } \\
\text { disagree }\end{array}$ \\
\hline \multicolumn{7}{|c|}{ By region } \\
\hline Asia and ME & $23 \%$ & $32 \%$ & $21 \%$ & $24 \%$ & $55 \%$ & $45 \%$ \\
\hline E. Africa & $21 \%$ & $31 \%$ & $26 \%$ & $22 \%$ & $53 \%$ & $47 \%$ \\
\hline W. Africa & $20 \%$ & $33 \%$ & $24 \%$ & $23 \%$ & $53 \%$ & $47 \%$ \\
\hline Europe & $24 \%$ & $28 \%$ & $27 \%$ & $21 \%$ & $52 \%$ & $48 \%$ \\
\hline L. America & $19 \%$ & $34 \%$ & $22 \%$ & $24 \%$ & $53 \%$ & $47 \%$ \\
\hline \multicolumn{7}{|c|}{ By cereal } \\
\hline Maize & $20 \%$ & $33 \%$ & $25 \%$ & $21 \%$ & $53 \%$ & $47 \%$ \\
\hline White maize & $19 \%$ & $34 \%$ & $25 \%$ & $21 \%$ & $54 \%$ & $46 \%$ \\
\hline Rice & $23 \%$ & $30 \%$ & $23 \%$ & $25 \%$ & $52 \%$ & $48 \%$ \\
\hline Wheat & $24 \%$ & $31 \%$ & $22 \%$ & $24 \%$ & $54 \%$ & $46 \%$ \\
\hline \multicolumn{7}{|c|}{ All regions and cereals } \\
\hline Total & $21 \%$ & $32 \%$ & $23 \%$ & $23 \%$ & $54 \%$ & $46 \%$ \\
\hline
\end{tabular}

Source: Own calculations with GIEWS price data. 
Figure 5a: The direction of lagged monthly price movements on international (month $t$ ) and domestic (month $t+1$ ) markets - agreement and disagreement by region

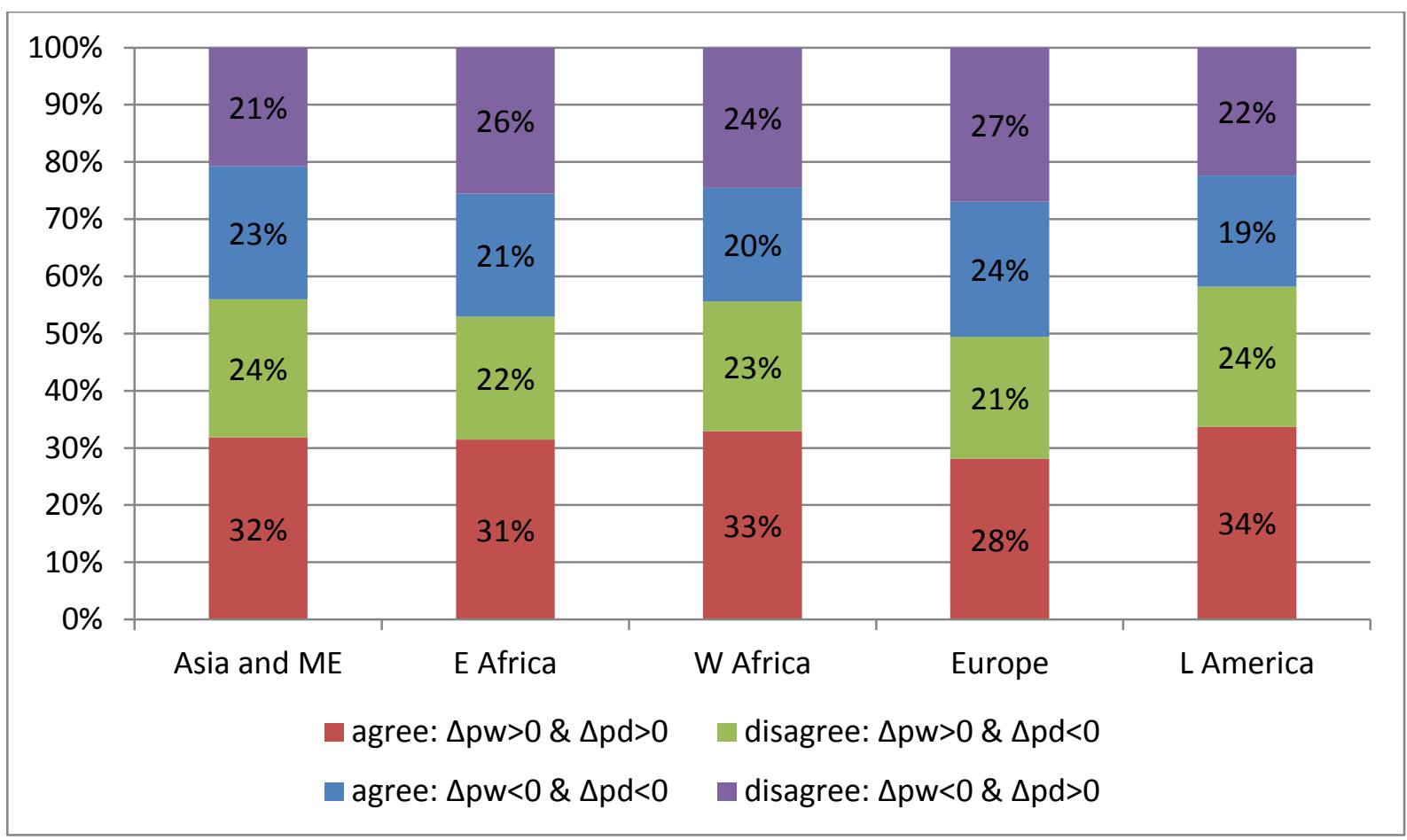

Source: Own calculations with GIEWS price data.

Table 13 and Figures $5 \mathrm{a}$ and $5 \mathrm{~b}$ show that these results do not change appreciably when lagged price changes are considered (international price changes in month $t$ and domestic price change in month $t+1)$. The only perhaps notable change is that the share of agreements between international and European price changes falls from $56 \%$ to $52 \%$ when lagged changes are considered. Hence, to the extent that European prices co-move with international prices, they appear to do so contemporaneously at the monthly frequency. 
Figure 5b: The direction of lagged monthly price movements on international (month $t$ ) and domestic (month $t+1$ ) markets - agreement and disagreement by cereal

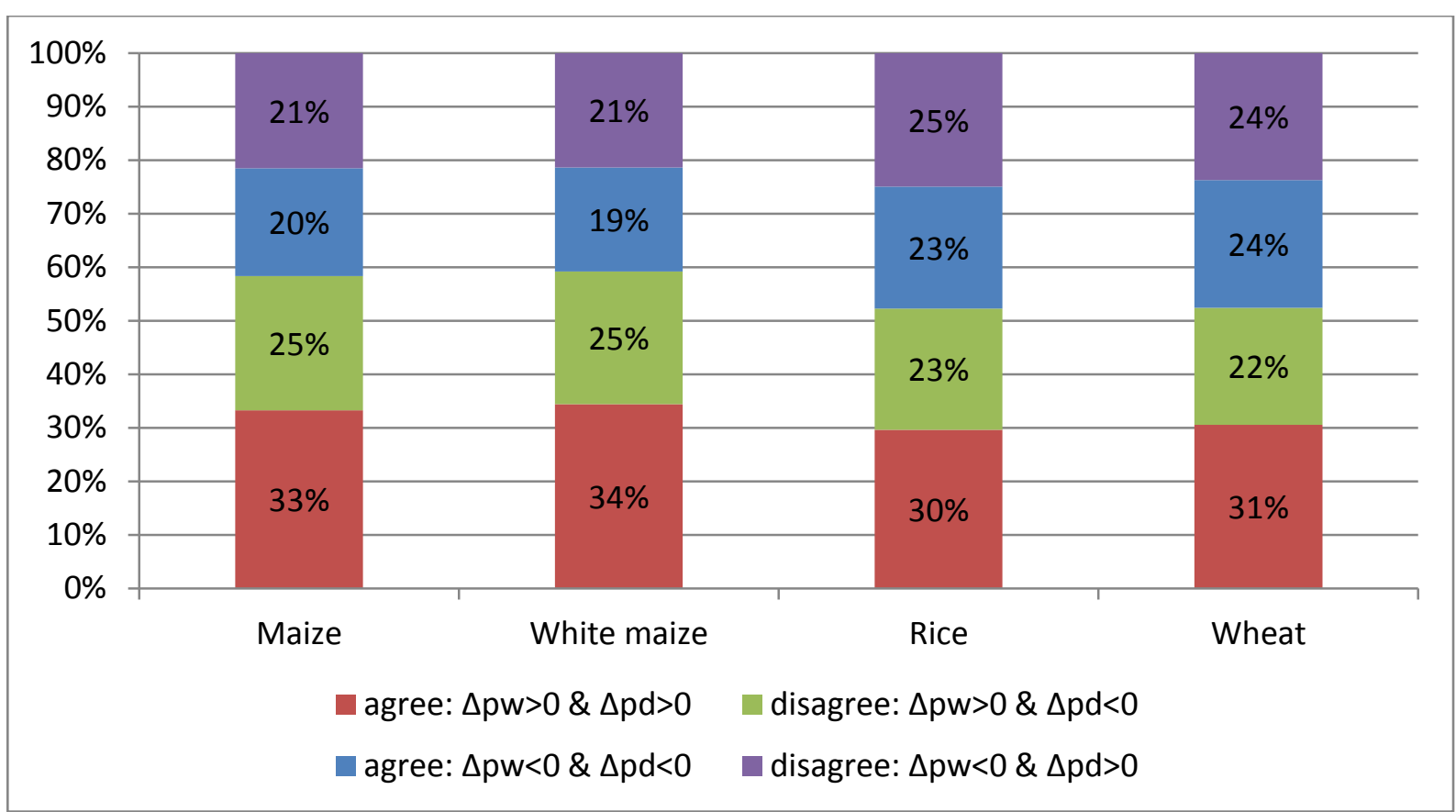

Source: Own calculations with GIEWS price data.

As expected, agreement between the direction of international and domestic price becomes more frequent when quarterly rather than monthly price changes are considered (Table 14). Focusing on quarterly rather than on monthly price changes eliminates smaller short-run price fluctuations and accounts for possible lags in PT. With quarterly data the overall share of agreements in the direction of price changes increases to $56 \%$ (from $54 \%$ with monthly data in Table 12). This increase in the share of agreements takes place only in phases of increasing international prices. With monthly data $58 \%$ of all increasing international prices coincide with increasing domestic prices; with quarterly data this share increases to $61 \%$ (35\% of $57 \%$ ). In contrast, the share of decreasing international prices that coincide with decreasing domestic prices is unaffected by the shift from monthly to quarterly data, remaining unchanged at $49 \%$ ( $21 \%$ of $43 \%)$.

The share of agreements increases in particular in Asia (from 53\% with monthly data to $60 \%$ with quarterly data) and in Europe (from $56 \%$ with monthly data to $72 \%$ with quarterly data). The share of agreements also increases for East Africa and for Latin America, but it decreases (from 53\% with monthly data to $51 \%$ with quarterly data) for West Africa (see also Figure 6a). Comparing Tables 12 and 14 also reveals that moving from monthly to quarterly price changes leads to an increased share of agreement for all cereals except white maize (see also Figure 6b).

Finally, Table 15 reveals that with annual data the overall share of agreements in the direction of price changes remains unchanged at $56 \%$ as with quarterly data. However, the share of agreements in phases of increasing international prices increases strongly; with quarterly data $61 \%$ of all increasing international prices coincide with increasing domestic prices; with annual data this share climbs to $67 \%$. In contrast, the share of decreasing international prices that coincide with decreasing domestic prices falls from $49 \%$ with quarterly data to $38 \%$ with annual data. Especially striking are the increases in the shares of agreements for Asia (from $60 \%$ with quarterly data to $65 \%$ with annual data) and Europe (from $72 \%$ to $100 \%$ ) and for rice (from $59 \%$ to $64 \%$ ) and wheat (from $58 \%$ to $69 \%$ ) (see also Figures $7 \mathrm{a}$ and $7 \mathrm{~b}$ ). 
Table 14: The direction of quarterly price movements on domestic and international markets agreement and disagreement by region and cereal

\begin{tabular}{|c|c|c|c|c|c|c|}
\hline & $\begin{array}{c}\text { Agree: } \\
\Delta p w<0 \\
\& \\
\Delta p d<0\end{array}$ & $\begin{array}{c}\text { Agree: } \\
\Delta p w>0 \\
\& \\
\Delta p d>0\end{array}$ & $\begin{array}{c}\text { Disagree: } \\
\Delta p w>0 \\
\& \\
\Delta p d<0\end{array}$ & $\begin{array}{c}\text { Disagree: } \\
\Delta p w<0 \\
\& \\
\Delta p d>0\end{array}$ & $\begin{array}{l}\text { Sum: } \\
\text { agree }\end{array}$ & $\begin{array}{c}\text { Sum: } \\
\text { disagree }\end{array}$ \\
\hline \multicolumn{7}{|c|}{ By region } \\
\hline Asia and ME & $22 \%$ & $38 \%$ & $22 \%$ & $18 \%$ & $60 \%$ & $40 \%$ \\
\hline E. Africa & $22 \%$ & $35 \%$ & $20 \%$ & $23 \%$ & $57 \%$ & $43 \%$ \\
\hline W. Africa & $18 \%$ & $33 \%$ & $24 \%$ & $25 \%$ & $51 \%$ & $49 \%$ \\
\hline Europe & $31 \%$ & $41 \%$ & $14 \%$ & $14 \%$ & $72 \%$ & $28 \%$ \\
\hline L. America & $20 \%$ & $36 \%$ & $23 \%$ & $21 \%$ & $57 \%$ & $43 \%$ \\
\hline \multicolumn{7}{|c|}{ By cereal } \\
\hline Maize & $22 \%$ & $36 \%$ & $21 \%$ & $22 \%$ & $58 \%$ & $42 \%$ \\
\hline White maize & $17 \%$ & $34 \%$ & $25 \%$ & $24 \%$ & $51 \%$ & $49 \%$ \\
\hline Rice & $22 \%$ & $37 \%$ & $20 \%$ & $21 \%$ & $59 \%$ & $41 \%$ \\
\hline Wheat & $23 \%$ & $35 \%$ & $22 \%$ & $20 \%$ & $58 \%$ & $42 \%$ \\
\hline \multicolumn{7}{|c|}{ All regions and cereals } \\
\hline Total & $21 \%$ & $35 \%$ & $22 \%$ & $22 \%$ & $56 \%$ & $44 \%$ \\
\hline
\end{tabular}

Source: Own calculations with GIEWS price data.

Figure 6a: The direction of quarterly price movements on domestic and international markets agreement and disagreement by region

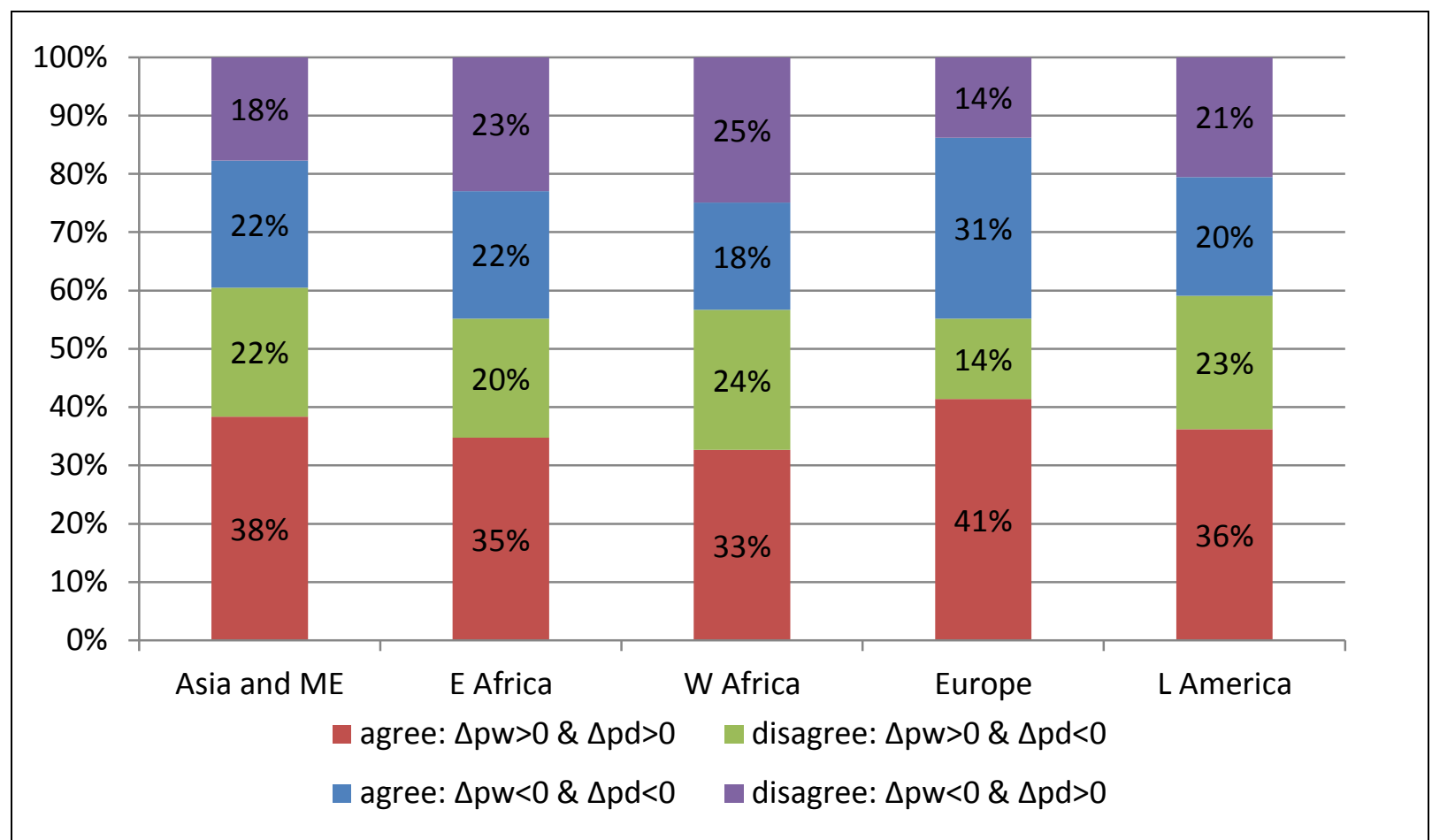

Source: Own calculations with GIEWS price data.

Overall, the results presented here support the findings of generally weak PT that were derived from the VECM analysis in the previous sections. They suggest that co-movement of international and domestic prices is more frequent than movement in opposite directions, but the imbalance is not pronounced and movement in opposite directions occurs often $(47 \%$ of all monthly price movements, $44 \%$ of all quarterly price movements, and $44 \%$ of all annual price movements). Perhaps surprisingly, differences in the direction of change are as often due to falling international prices that are not reflected in falling domestic prices $(23 \%, 22 \%$ and $24 \%$ of all cases in monthly, quarterly and 
annual data, respectively) as they are to increasing international prices that are not reflected in increasing domestic prices $(23 \%, 22 \%$ and $20 \%$ of all cases, respectively). Intervention to shield domestic markets from increasing international prices would lead to the latter type of disagreement, but cases in which domestic markets fail to fall with international prices are equally common.

Figure 6b: The direction of quarterly price movements on domestic and international markets agreement and disagreement by cereal

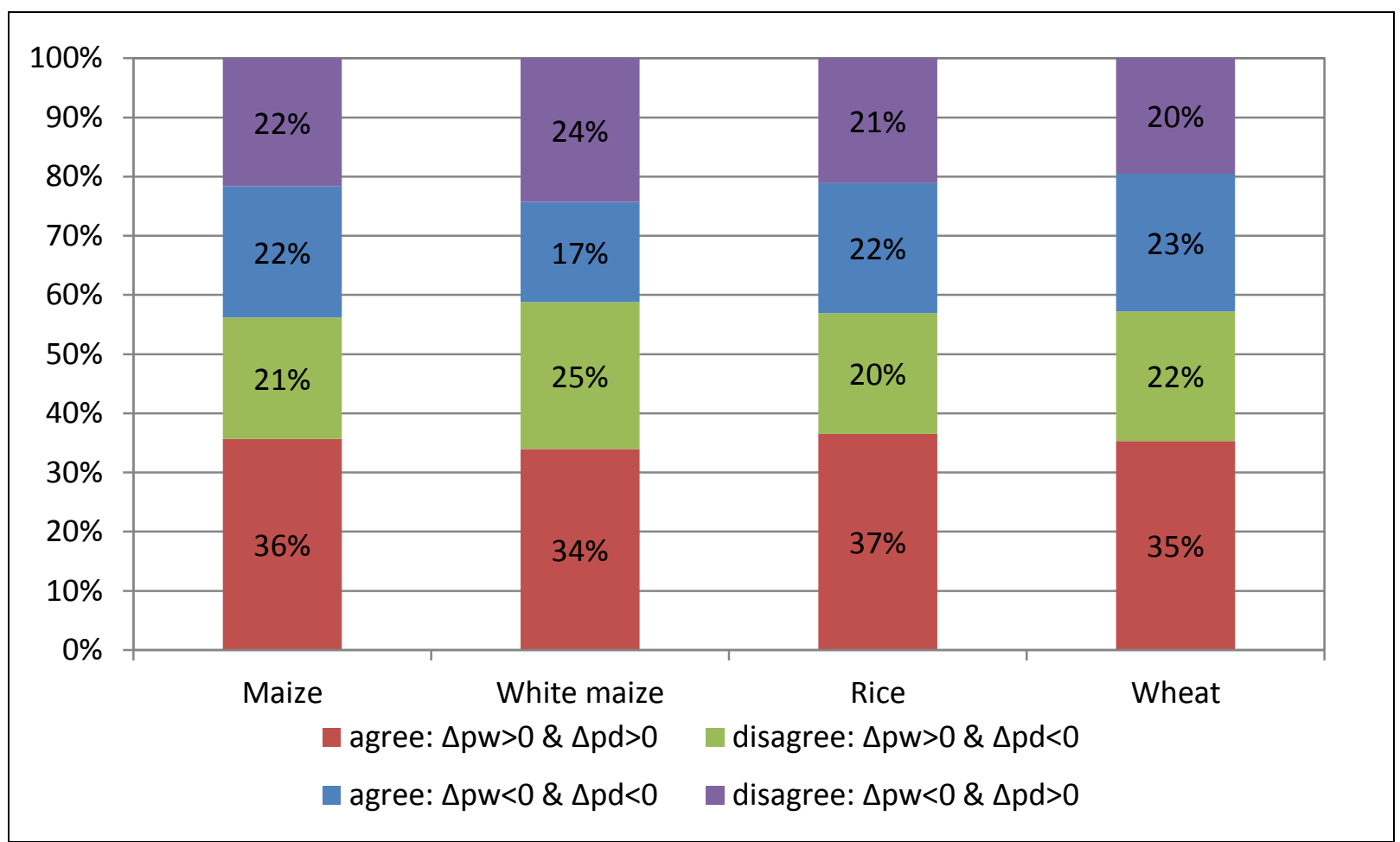

Source: Own calculations with GIEWS price data.

Table 15: The direction of annual price movements on domestic and international markets agreement and disagreement by region and cereal

\begin{tabular}{|c|c|c|c|c|c|c|}
\hline & $\begin{array}{c}\text { Agree: } \\
\Delta \mathrm{pw}<0 \\
\& \\
\Delta \mathrm{pd}<0\end{array}$ & $\begin{array}{c}\text { Agree: } \\
\Delta \text { pw }>0 \\
\& \\
\Delta p d>0\end{array}$ & $\begin{array}{c}\text { Disagree: } \\
\Delta p w>0 \\
\& \\
\Delta p d<0\end{array}$ & $\begin{array}{c}\text { Disagree: } \\
\Delta p w<0 \\
\& \\
\Delta p d>0\end{array}$ & $\begin{array}{l}\text { Sum: } \\
\text { agree }\end{array}$ & $\begin{array}{c}\text { Sum: } \\
\text { disagree }\end{array}$ \\
\hline \multicolumn{7}{|c|}{ By region } \\
\hline Asia and ME & $16 \%$ & $49 \%$ & $20 \%$ & $15 \%$ & $65 \%$ & $35 \%$ \\
\hline E. Africa & $16 \%$ & $40 \%$ & $19 \%$ & $25 \%$ & $56 \%$ & $44 \%$ \\
\hline W. Africa & $11 \%$ & $35 \%$ & $22 \%$ & $32 \%$ & $46 \%$ & $54 \%$ \\
\hline Europe & $67 \%$ & $33 \%$ & $0 \%$ & $0 \%$ & $100 \%$ & $0 \%$ \\
\hline L. America & $15 \%$ & $45 \%$ & $22 \%$ & $18 \%$ & $60 \%$ & $40 \%$ \\
\hline \multicolumn{7}{|c|}{ By cereal } \\
\hline Maize & $12 \%$ & $34 \%$ & $25 \%$ & $30 \%$ & $46 \%$ & $54 \%$ \\
\hline White maize & $11 \%$ & $38 \%$ & $19 \%$ & $32 \%$ & $49 \%$ & $51 \%$ \\
\hline Rice & $18 \%$ & $46 \%$ & $19 \%$ & $17 \%$ & $64 \%$ & $36 \%$ \\
\hline Wheat & $20 \%$ & $49 \%$ & $18 \%$ & $13 \%$ & $69 \%$ & $31 \%$ \\
\hline \multicolumn{7}{|c|}{ All regions and cereals } \\
\hline Total & $15 \%$ & $41 \%$ & $20 \%$ & $24 \%$ & $56 \%$ & $44 \%$ \\
\hline
\end{tabular}

Source: Own calculations with GIEWS price data. 
Figure 7a: The direction of annual price movements on domestic and international markets agreement and disagreement by region

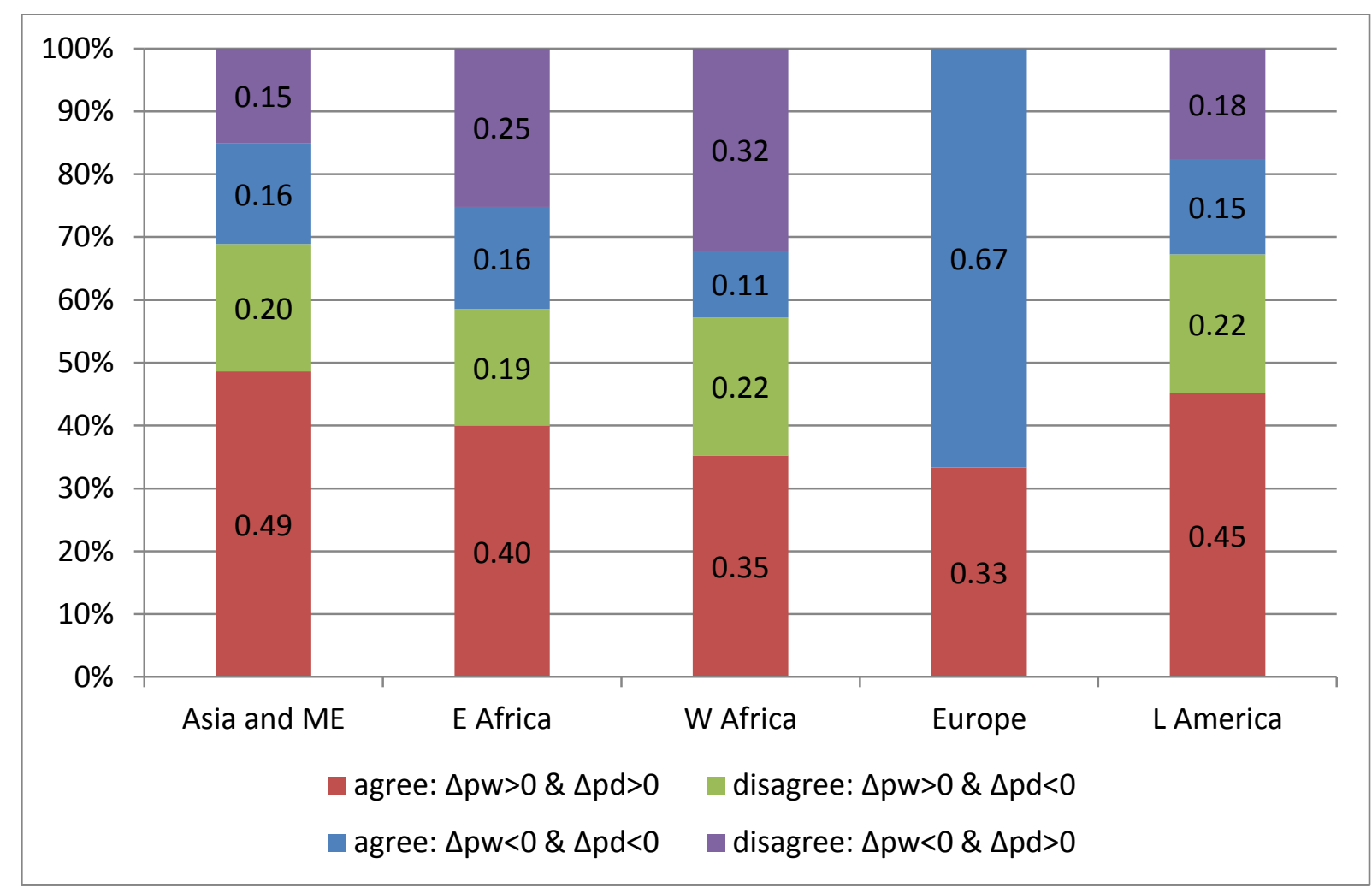

Source: Own calculations with GIEWS price data.

Figure 7b: The direction of annual price movements on domestic and international markets agreement and disagreement by cereal

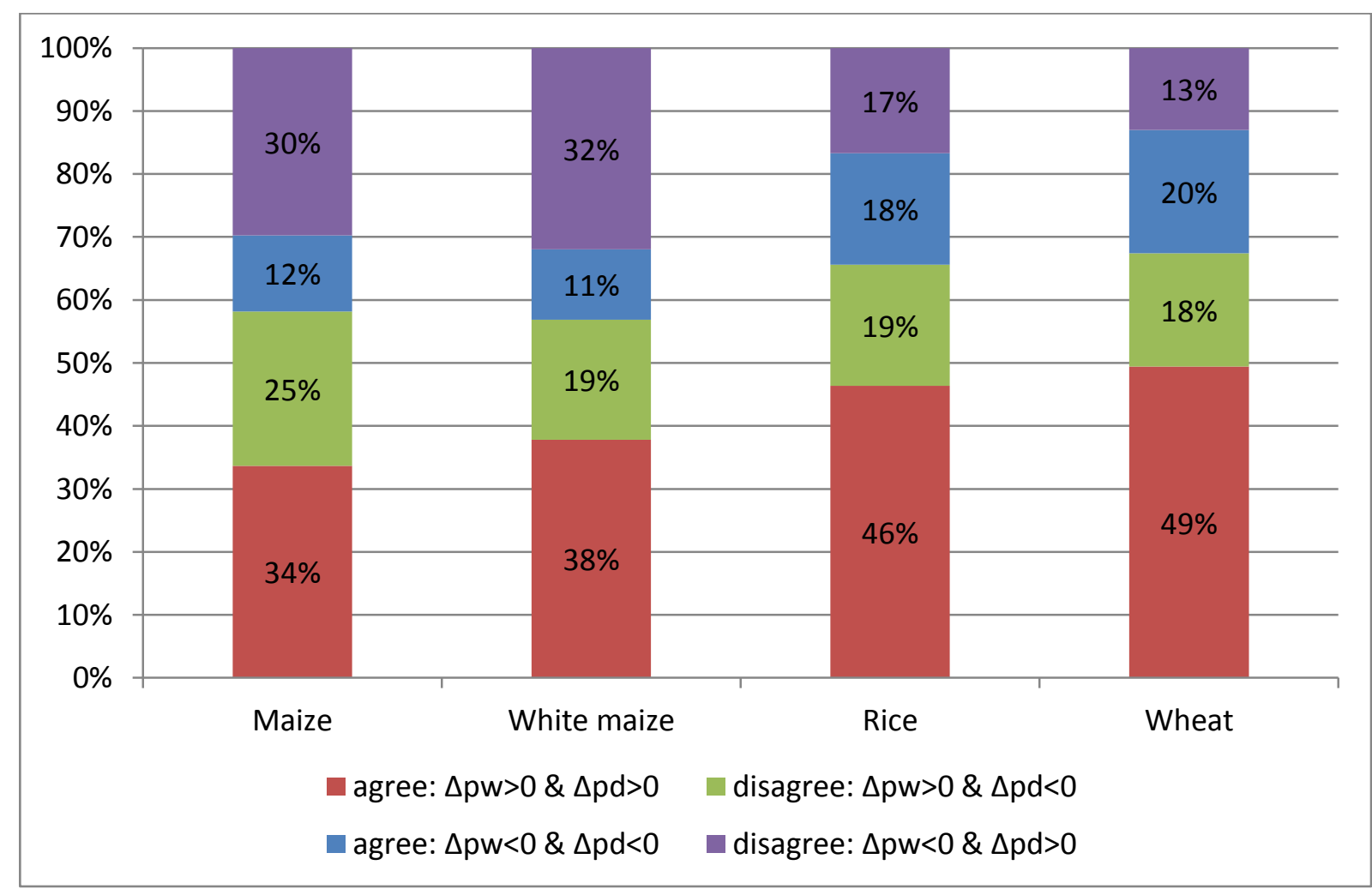

Source: Own calculations with GIEWS price data. 


\section{Price volatility}

In this section we compare cereal price volatility on international and domestic markets. Volatility is measured as the standard deviation of returns (the log ratio of prices in month $t$ to prices in month $t$ 1). Results are summarized in Figures 8 through 11 and Table 15.

First, Figure 8 illustrates that median volatility over all domestic cereal prices in the GIEWS dataset is higher after July 2007 than before (see also Table 15). There is no difference between the median volatilities of those prices that are cointegrated with the corresponding international prices and those that are not. This suggests that on average, countries that have decoupled their domestic cereal prices from international prices have not benefited from reduced price volatility as a result.

Figure 8: Boxplots of volatilities for cointegrated and non-cointegrated domestic prices, pre- and post-2007, maize, rice and wheat combined

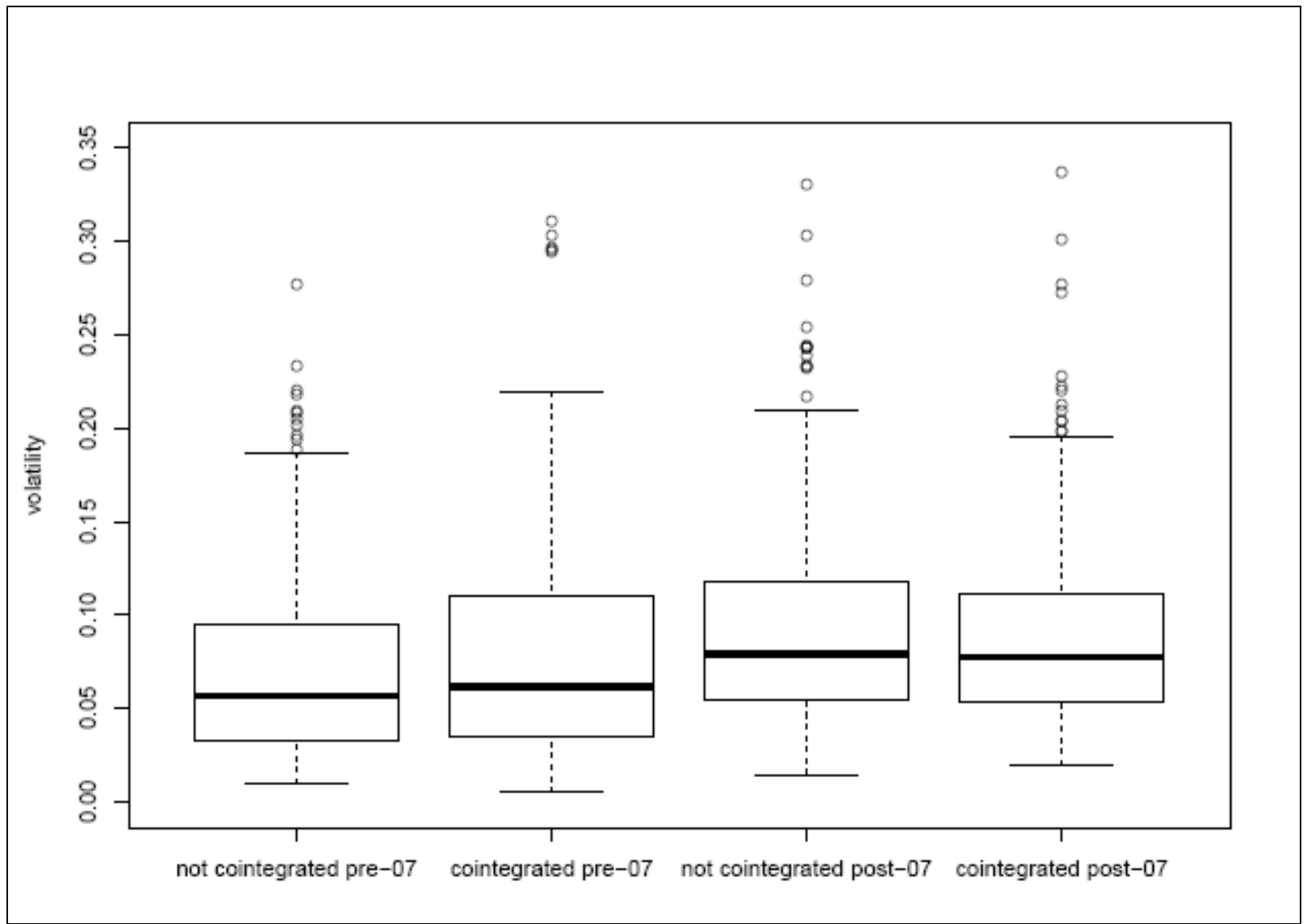

Source: Own calculations with GIEWS price data.

Table 16 and the results presented in Figures 9 through 11 for maize, rice and wheat respectively indicates that in general, domestic prices are most volatile in East and West Africa, followed by Latin America and Latin America. This pattern is interrupted somewhat for wheat, but the calculated volatilities for wheat are based on relatively few observations and, therefore, are less reliable. For maize in all regions we observe that median volatilities are lower for prices that are not cointegrated with the corresponding international prices, suggesting that decoupling prices does results in lower volatility on average for maize. However, this is not the case for rice and wheat, where noncointegrated domestic prices are more, rather than less volatile than cointegrated prices. 
Table 16: The volatility of monthly international and domestic cereal prices

\begin{tabular}{|c|c|c|c|c|c|c|c|c|c|c|c|c|}
\hline \multirow[b]{2}{*}{ Prices } & \multicolumn{3}{|c|}{ Maize } & \multicolumn{3}{|c|}{ Rice } & \multicolumn{3}{|c|}{ Wheat } & \multicolumn{3}{|c|}{ All cereals } \\
\hline & $\begin{array}{c}\text { Median } \\
\text { volatility }\end{array}$ & $\begin{array}{l}\text { Standard } \\
\text { deviation }\end{array}$ & $\mathbf{n}$ & $\begin{array}{c}\text { Median } \\
\text { volatility }\end{array}$ & $\begin{array}{l}\text { Standard } \\
\text { deviation }\end{array}$ & $\mathbf{n}$ & $\begin{array}{c}\text { Median } \\
\text { volatility }\end{array}$ & $\begin{array}{l}\text { Standard } \\
\text { deviation }\end{array}$ & $\mathbf{n}$ & $\begin{array}{c}\text { Median } \\
\text { volatility }\end{array}$ & $\begin{array}{l}\text { Standard } \\
\text { deviation }\end{array}$ & $\mathbf{n}$ \\
\hline International & 0.06 & & & 0.07 & & & 0.06 & & & 0.06 & & \\
\hline All domestic & 0.11 & 0.06 & 179 & 0.06 & 0.05 & 262 & 0.08 & 0.04 & 57 & 0.07 & 0.06 & 498 \\
\hline Cointegrated & 0.14 & 0.06 & 55 & 0.06 & 0.06 & 139 & 0.09 & 0.04 & 14 & 0.07 & 0.07 & 208 \\
\hline Non-cointegrated & 0.11 & 0.06 & 124 & 0.06 & 0.03 & 123 & 0.07 & 0.04 & 43 & 0.07 & 0.05 & 290 \\
\hline Pre-2007 & 0.10 & 0.08 & 153 & 0.04 & 0.04 & 234 & 0.05 & 0.04 & 51 & 0.06 & 0.07 & 438 \\
\hline Post-2007 & 0.11 & 0.06 & 179 & 0.06 & 0.05 & 262 & 0.09 & 0.05 & 57 & 0.08 & 0.06 & 498 \\
\hline Cointegrated pre-2007 & 0.14 & 0.10 & 51 & 0.05 & 0.05 & 119 & 0.08 & 0.06 & 14 & 0.06 & 0.08 & 184 \\
\hline Cointegrated post-2007 & 0.14 & 0.06 & 55 & 0.06 & 0.06 & 139 & 0.10 & 0.03 & 14 & 0.08 & 0.07 & 208 \\
\hline Non-cointegrated pre-2007 & 0.09 & 0.07 & 102 & 0.04 & 0.03 & 115 & 0.05 & 0.03 & 37 & 0.06 & 0.06 & 254 \\
\hline Non-cointegrated post-2007 & 0.11 & 0.06 & 124 & 0.06 & 0.03 & 123 & 0.08 & 0.05 & 43 & 0.08 & 0.05 & 290 \\
\hline East Africa & 0.15 & 0.05 & 59 & 0.09 & 0.03 & 35 & 0.09 & 0.03 & 14 & 0.11 & 0.05 & 108 \\
\hline West Africa & 0.13 & 0.05 & 43 & 0.07 & 0.03 & 81 & 0.13 & 0.06 & 6 & 0.08 & 0.05 & 130 \\
\hline Latin America & 0.08 & 0.05 & 58 & 0.05 & 0.02 & 70 & 0.07 & 0.03 & 11 & 0.06 & 0.04 & 139 \\
\hline Asia & 0.07 & 0.08 & 15 & 0.05 & 0.07 & 74 & 0.06 & 0.03 & 24 & 0.05 & 0.07 & 113 \\
\hline Other & 0.11 & 0.03 & 4 & 0.04 & 0.02 & 2 & 0.10 & 0.00 & 2 & 0.10 & 0.04 & 8 \\
\hline E Africa cointegrated & 0.18 & 0.05 & 21 & 0.09 & 0.03 & 22 & 0.09 & 0.04 & 8 & 0.12 & 0.06 & 51 \\
\hline E Africa non-cointegrated & 0.13 & 0.05 & 38 & 0.09 & 0.03 & 13 & 0.09 & 0.02 & 6 & 0.11 & 0.05 & 57 \\
\hline W Africa cointegrated & 0.16 & 0.02 & 9 & 0.06 & 0.03 & 58 & 0.14 & - & 1 & 0.07 & 0.04 & 68 \\
\hline W Africa non-cointegrated & 0.11 & 0.06 & 34 & 0.07 & 0.04 & 23 & 0.11 & 0.07 & 5 & 0.09 & 0.06 & 62 \\
\hline L America cointegrated & 0.09 & 0.06 & 22 & 0.04 & 0.02 & 39 & 0.05 & 0.04 & 2 & 0.05 & 0.05 & 63 \\
\hline L America non-cointegrated & 0.08 & 0.04 & 36 & 0.06 & 0.02 & 31 & 0.07 & 0.02 & 9 & 0.07 & 0.04 & 76 \\
\hline Asia cointegrated & 0.07 & 0.01 & 2 & 0.06 & 0.14 & 18 & 0.09 & 0.01 & 3 & 0.06 & 0.12 & 23 \\
\hline Asia non-cointegrated & 0.06 & 0.08 & 13 & 0.05 & 0.02 & 56 & 0.05 & 0.03 & 21 & 0.05 & 0.04 & 90 \\
\hline Other cointegrated & 0.11 & - & 1 & 0.04 & 0.02 & 2 & - & - & 0 & 0.05 & 0.04 & 3 \\
\hline Other non-cointegrated & 0.11 & 0.04 & 3 & - & - & 0 & 0.10 & 0.00 & 2 & 0.10 & 0.03 & 5 \\
\hline
\end{tabular}

Note: ' $n$ ' is the number of individual price series that underlie the volatility calculation. Volatility is calculated as the standard deviation of the log ratio of prices in the current month to prices in the previous month.

Source: Own calculations with GIEWS price data. 
Figure 9: Boxplots of domestic price volatilities for maize by region, and the volatility of the international maize price (vertical dotted line)

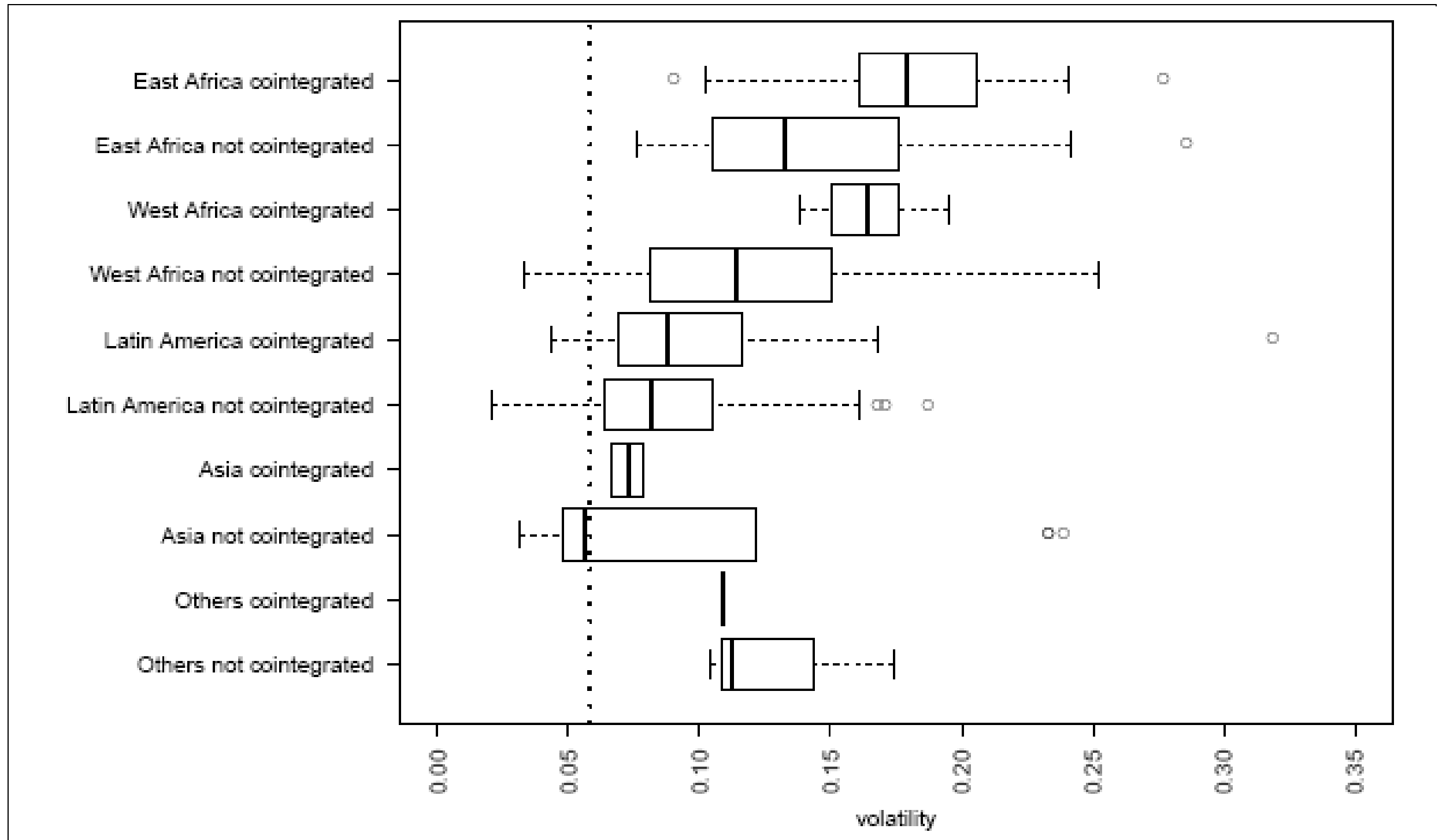

Source: Own calculations with GIEWS price data. 
Figure 10: Boxplots of domestic price volatilities for rice by region, and the volatility of the international rice price (vertical dotted line)

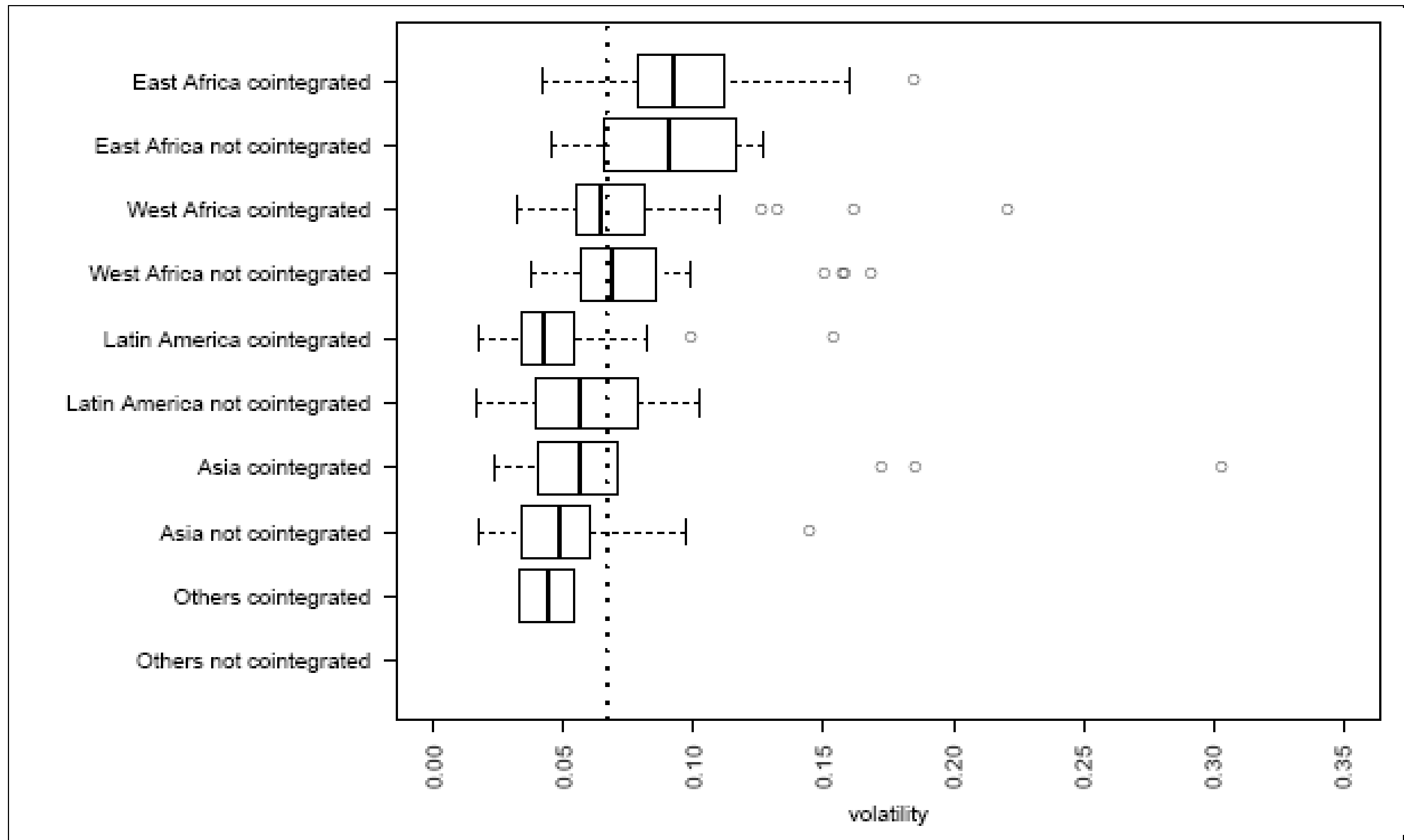

Source: Own calculations with GIEWS price data.

जि 
Figure 11: Boxplots of domestic price volatilities for wheat by region, and the volatility of the international wheat price (vertical dotted line)

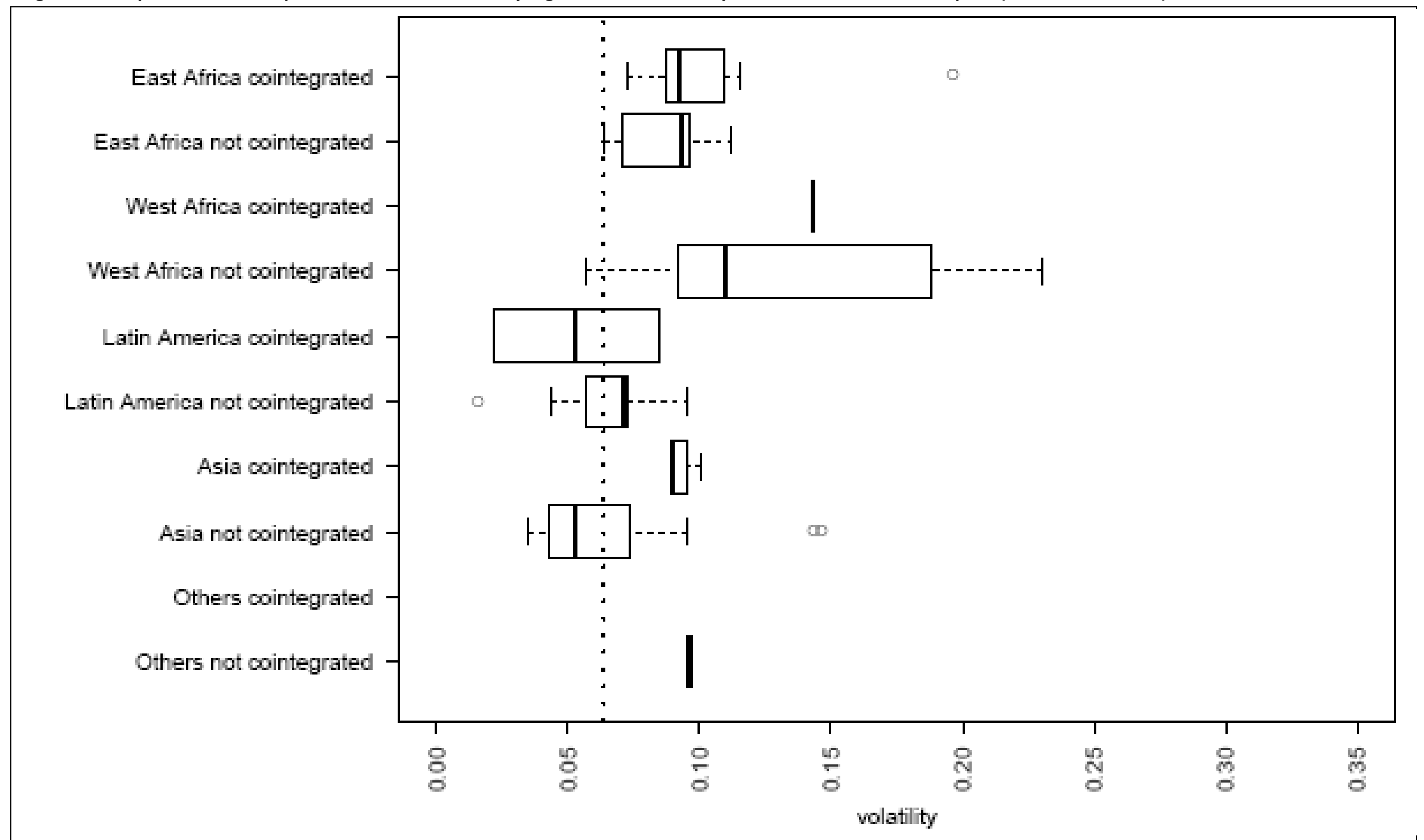

Source: Own calculations with GIEWS price data. 
Finally, comparing domestic price volatility with international price volatility (first lines of Table 15) reveals that on average, domestic maize and wheat prices are more volatile than the corresponding international prices, while domestic rice prices are less volatile. Figures 9 through 11, in which international price volatility is depicted by the dashed vertical lines, break this comparison down by region. Figure 9 shows that the great majority of domestic maize prices in all regions are considerably more volatile than the international maize price. For rice (Figure 10), domestic prices in East Africa are more volatile than the international price, equally volatile on average in West Africa, and less volatile in Latin America and Asia. For wheat the picture (Figure 11) is very mixed, with domestic prices in East and West Africa considerably more volatile than the international price, and Latin America and Asia showing mixed results. Again, as Table 15 shows, there are relatively few observations for wheat in some regions in the GIEWS data, so these last results must be interpreted with caution.

\section{Discussion}

The analysis above generates a number of insights into the nature of PT from international to domestic cereal markets. First, $79 \%$ of the international/domestic price pairs in our sample of PT studies from the literature are cointegrated compared with $43 \%$ in our own estimates based on FAO GIEWS data. Hence, regardless of which database is used, many of the studied price pairs are not characterized by cointegration and thus do not provide evidence of stable PT. This is especially the case if we consider that the literature sample most likely suffers from publication bias that leads to an overrepresentation of findings of cointegration. Overall, maize markets are characterized by a below average prevalence of cointegration, and rice markets by an above average prevalence. Which regions of the world display higher/lower shares of cointegration depends on which dataset is considered: according to the literature sample, domestic prices in Africa are less likely than average to be cointegrated with corresponding international prices, but our own estimates generated with GIEWS data suggest that domestic prices in Asia are least likely to be cointegrated with international prices.

Overall, both the literature and our own GIEWS-based estimated point to average long-run PT coefficients of roughly 0.75 and average adjustment parameters of roughly $0.09-0.11$. This suggests that on average roughly three-quarters of a change in international prices will be transmitted to domestic markets, and that it takes approximately 6-7 months for one-half of a given price shock on international cereal markets to be transmitted to domestic markets. For wheat and maize it is exclusively the domestic prices that react to disequilibrium between themselves and the corresponding international prices. But in the case of rice, roughly $40 \%$ of all price pairs display international price reactions to disequilibrium as well. Hence, the determination of international prices for rice appears to differ fundamentally from that for wheat and maize. The reasons for this difference would be an interesting topic for future research.

If we compare PT in the period prior to July 2007 with PT in the period thereafter, no clear pattern emerges. On maize markets the long-run PT coefficients $(\beta)$ have fallen considerably since mid- 2007 . This could be interpreted as evidence of a certain degree of decoupling of domestic from international prices. On rice and wheat markets the results depend on whether all price pairs or only cointegrated price pairs are considered. In the latter case there is evidence that the long-run PT coefficients have increased, but at the same time the short-run adjustment coefficients $(\alpha)$ have fallen, suggesting that PT has become more complete but slower since mid-2007 for rice and wheat.

Employing meta-regression analysis to explain variations in long-run PT coefficients $(\beta)$ between domestic and international prices fails to generate compelling results. The meta-regressions for the adjustment parameters $(\alpha)$ do produce some more suggestive results. All other things being equal, there is some evidence of more rapid PT for maize than for wheat and rice, and more rapid PT in West Africa than in other regions. An increasing ratio of net imports to domestic consumption is 
associated with slower PT, which may be an indication of increased intervention on politically more sensitive markets. There is evidence that trade openness is positively associated with the speed of PT, but this effect is only significant in the pre-July 2007 period. In this period there is also robust evidence that the presence of an STE is associated with more rapid PT. Finally, there is some puzzling indication that improved logistics is correlated with slower PT.

The analysis of agreement in the direction in price changes on international and domestic markets suggests that the frequency of agreement is quite low at the monthly level, and only somewhat higher at the quarterly level. This lack of agreement is especially pronounced when international prices are falling; in this case domestic prices only fall as well in roughly $50 \%$ of all cases, which is what one would expect if price movements on international and domestic markets were completely independent. When international prices are increasing, there is a higher probability that domestic prices will increase as well, especially at the quarterly level for Europe, Asia, East Africa and Latin America. Overall these results support the findings of generally weak PT that were derived from the cointegration analysis.

The analysis of domestic price volatility reveals that median volatility has increased since July 2007. There is no difference between the median volatilities of those prices that are cointegrated with the corresponding international prices and those that are not. This suggests that on average, countries that have decoupled their domestic cereal prices from international prices have not benefited from reduced price volatility as a result. The analysis reveals that in general, domestic prices are most volatile in East and West Africa, followed by Latin America and Latin America. Furthermore, on average domestic maize and wheat prices are more volatile than the corresponding international prices, while domestic rice prices are less volatile.

The results presented here must be interpreted with caution. First, a lack of cointegration between two prices does not necessarily mean that there is no PT between (McNew and Fackler, 1997). The underlying PT relationship may be characterized by regime-dependence, for example as a result of policy intervention or shifts between net import and net export positions. Hence, failure to find evidence of cointegration might be due to a failure to test for the right type of cointegration. The higher share of cointegrated price pairs in the literature sample is likely due to publication bias that leads to an overrepresentation of 'significant' results. However, the authors of studies in the literature might also find more evidence of cointegration because they employ models and tests that are better tailored to the specific country/product settings that they study. The strength of the GIEWS price data is that it provides broad and consistent coverage of a large number of country/product combinations. However, the sheer number of price series available in GIEWS means it is not possible to implement a detailed modeling strategy for each individual series. Instead, we must resort to a uniform modeling strategy that can be automated. We have estimated one slightly more flexible VECM that allows for a regime shift in July 2007, but this is no substitute for careful, case-by-case specification and estimation of an appropriate model for each individual price pair.

Second, the GIEWS price series are quite short. Few series have more than 150 monthly observations, and many have considerably less. It is reasonable to expect that the nature of cereal price transmission from international to domestic markets has changed in recent years at prices have increased and become more volatile, and some of the results that we produce with the GIEWS data appear to confirm this expectation. There are, however, only roughly 55 monthly observations available for the period since 2007.

Additional work might lead to additional or more robust insights into PT. First, the simple VECM employed to estimate the GIEWS price data might be made somewhat more flexible. It could be modified to allow for asymmetric price transmission, i.e. to test whether increases in international prices are transmitted to domestic prices in the same manner as decreases (von Cramon-Taubadel, 1998). The results of the simple non-parametric analysis of agreement in the direction of international and domestic price changes suggests that increasing international prices are being 
transmitted more often to domestic prices than decreasing international prices. Alternatively, it might be possible to estimate threshold VECMs (TVECMs) with the GIEWS data (Goodwin and Piggott, 2001; Greb et al., 2011). The TVECM can account for phases with and without trade and trade reversals and by distinguishing between these phases or regimes provide better estimates of PT parameters.

Second, the analysis of agreement in the direction of price changes on international and domestic markets could be extended to consider half-yearly and annual price changes, and to explore possible delays in the response of domestic to international prices. It may be that more agreement in the direction of price changes is found if current international price changes are aligned with domestic price changes several months later, and that the length of this lag varies between countries and/or products. 


\section{References}

Akaike, H. (1974). A new look at the statistical model identification. IEEE Transactions on Automatic Control 19: 716-723.

Ackerman, K. (1997). State trading enterprises: their role as importers. Agricultural Outlook. Economic Research Service/USDA. November 1997: 31-37.

Ackerman, K. (1998). State trading enterprises in world agricultural trade. Agriculture in the WTO. Economic Research Service/USDA. December 1998: 43-47.

Ackermann, K. \& Dixit, P. (1999): Introduction to State Trading in Agriculture. Economic Research Service/USDA, Agricultural Economics Report No. AER 783, November 1999.

Ardeni, P. G. (1989). Does the Law of One price Really Hold for Commodity Prices? American Journal of Agricultural Economics 71: 661-669.

Barrett, C. and Li, J. (2002). Distinguishing between equilibrium and integration in spatial price analysis. American Journal of Agricultural Economics 84: 292-307.

Chang, H.-H., \& de Gorter, H. (2004). Tariff rate import quotas, domestic market structure and agricultural support programs - The Case of Taiwanese Rice Imports. Selected paper prepared for presentation at the Western Agricultural Economics Association Annual Meeting, Honolulu, Hawaii, June 30-July 2, 2004: 1-28.

Dickey, D.A. and Fuller, W.A. (1979). Distribution of the estimators for autoregressive time series with a unit root. Journal of the American Statistical Association 74: 427-431.

Engle, R.F. and Granger, C.W.J. (1987). Cointegration and Error-correction: Representation, Estimation and Testing. Econometrica 55: 251-276.

Fackler, P. L. and Goodwin B. K. (2001). Spatial Price Analysis. In: Gardner B. and Rausser, G. (eds.), Handbook of Agriculture Economics, Vol. 1: 971-1024. Amsterdam: Elsevier Science B.V.

Gilbert, C.L. (2011). Grain Price Pass-Through, 2005-2009. In: Prakash, A. (ed.), Safeguarding Food Security in Volatile Global Markets. Rome, FAO.

Gregory, A.W. and Hansen, B.E. (1996). Residual-based tests for cointegration in models with regime shifts. Journal of Econometrics, 70: 99-126.

Gonzalez- Rivera, G. and Helfand, S. M. (2001). The Extent, Pattern, and Degree of Market Integration: A Multivariate Approach for the Brazilian Rice Market. American Journal of Agricultural Economics 83: 576-592.

Goodwin, B.K. and Piggott, N.E. (2001). Spatial Market Integration in the Presence of Threshold Effects. American Journal of Agricultural Economics 83(2): 302-317.

Greb, F., von Cramon-Taubadel, S., Krivobokova, T. and Munk, A. (2011). The estimation of threshold models in price transmission analysis. Discussion paper of the Courant Research Centre "Poverty, Equity and Growth in Developing Countries: Statistical Methods and Empirical Analyses" No. 103. Georg-August University Göttingen: 1-29. 
Gupta, S. and Mueller, R. (1982). Analyzing the Pricing Efficiency in Spatial Markets; Concept and Applications. European Review Agricultural Economics 9: 301-312.

Hassouneh, I., Serra, T. and Gil, J.M. (2010). Price transmission in the Spanish bovine sector: the BSE effect. Agricultural Economics 41:33-42.

Hassouneh, I., von Cramon-Taubadel, S., Serra, T. and Gil, J.M. (2012). Recent Developments in the Econometric Analysis of Price Transmission. TRANSFOP (Transparency of Food Pricing) Working Paper No. 2, www.transfop.eu: 1-27.

Johansen, S. (1988). Statistical analysis of cointegrating vectors. Journal of Economic Dynamics and Control 12: 231-254.

Kwiatkowski, D., Phillips, P., Schmidt, P. and Shin, Y. (1992). Testing the null hypothesis of stationarity against the alternative of a unit root. Journal of Econometrics 54: 159-178.

Meyer, J. (2004). Methoden zur Analyse von Preistransmissionsprozessen. Dissertation, GeorgAugust-Universität Göttingen.

Meyer, J., and von Cramon-Taubadel, S. (2004). Asymmetric Price Transmission: A Survey. Journal of Agricultural Economics 55(3): 581-611.

McNew, K., and Fackler, P.L. (1997). Testing Market Equilibrium: Is Cointegation Informative? Journal of Agricultural and Resource Economics 22(2): 191-207.

OECD (2007). Agricultural Policies in Non-OECD Countries - Monitoring and Evaluation. OECD, Paris.

Rapsomanikis, G., Hallam, D. and Conforti, P. (2003). Market Integration and Price Transmission in Selected Food and Cash Crop Markets of Developing Countries: Review and Applications. Commodity Market Review, FAO Commodities and Trade Division, Rome: 187-217.

Ravallion, M. (1986). Testing Market Integration. American Journal of Agriculture Economics 68: 102109.

Serra, T., Gil, J.M. and Goodwin, B. K. (2006). Local polynomial fitting and spatial price relationship: price transmission in EU pork markets. European Review of Agricultural Economics 33: 415436.

Serra, T. and Goodwin, B. K. (2003). Price transmission and asymmetric adjustment in the Spanish dairy sector. Applied Economics 35: 1889-1899.

Takayama, T. and Judge G.G. (1971). Spatial and Temporal Price Allocation Models. Amsterdam: North-Holland.

Teräsvirta, T., 1994. Specification, estimation, and evaluation of smooth transition autoregressive models. Journal of the American Statistical Association 89: 208-218.

Vavra, P. and Goodwin, B.K. (2005). Analysis of Price Transmission Along the Food Chain. OECD Food, Agriculture and Fisheries Working Papers 3, Paris, OECD: 1-58.

von Cramon-Taubadel, S. (1998). Estimating asymmetric Price Transmission with the Error Correction Representation: An Application to the German Pork Market. European Review of Agricultural Economics 25: 1-18. 
von Cramon-Taubadel, S. and Amikuzuno, J. (2012). Seasonal Variation in Price Transmission between Tomato Markets in Ghana. Journal of African Economies 21(4): 669-686.

Young, L. M. (1999). Prevalence and Reform of State Trading Importers in World Grain Markets. Canadian Journal of Agricultural Economics 47(4): 351-362.

Young, L. M., \& Abbott, P. C. (1998). Wheat-Importing State Trading Enterprises : Impacts on the World Wheat Market. Paper presented at the meetings of the American Agricultural Economics Association, Salt Lake City, August 2-5, 1998: 1-14. 


\section{Appendix}

\section{Appendix Table 1: Studies included in the literature sample}

\begin{tabular}{|c|c|c|c|c|}
\hline $\begin{array}{l}\text { Authors, } \\
\text { Year Published }\end{array}$ & Title & $\begin{array}{l}\text { Institution / } \\
\text { Publication }\end{array}$ & $\begin{array}{l}\text { Type of } \\
\text { publicati } \\
\text { on }\end{array}$ & $\begin{array}{c}\text { Number } \\
\text { of } \\
\text { market } \\
\text { pairs }\end{array}$ \\
\hline $\begin{array}{l}\text { Baquedano, Liefert \& } \\
\text { Shapouri, } 2011\end{array}$ & $\begin{array}{l}\text { World market integration for export and food crops in developing } \\
\text { countries: a case study for Mali and Nicaragua }\end{array}$ & $\begin{array}{l}\text { Agricultural } \\
\text { Economics }\end{array}$ & Journal & 4 \\
\hline $\begin{array}{l}\text { Djuric, Götz \& Glauben, } \\
2011 \text { \& }\end{array}$ & $\begin{array}{l}\text { Effects of the governmental market interventions on the wheat } \\
\text { market in Serbia during the food crisis } 2007 / 2008\end{array}$ & IAMO & Conference & 2 \\
\hline Ghoshray, 2011 & $\begin{array}{l}\text { Underlying Trends and International Price Transmission of } \\
\text { Agricultural Commodities }\end{array}$ & $A D B$ & Report & 10 \\
\hline Gilbert, 2011 & Grains Price Pass-Through, 2005-09 & FAO & Report & 10 \\
\hline Minot, 2011 & $\begin{array}{l}\text { Transmission of World Food Price Changes to Markets in Sub-Saharan } \\
\text { Africa }\end{array}$ & IFPRI & Report & 58 \\
\hline Myers \& Jayne, 2011 & $\begin{array}{l}\text { Multiple-regime spatial price transmission with an application to } \\
\text { maize markets in southern Africa }\end{array}$ & $\begin{array}{l}\text { American Journal of } \\
\text { Agricultural } \\
\text { Economics }\end{array}$ & Journal & 3 \\
\hline $\begin{array}{l}\text { Aldaz-Carroll, Varela \& } \\
\text { lacovone, } 2010\end{array}$ & $\begin{array}{l}\text { Boom, Bust and Up Again? Evolution, Drivers and Impact of } \\
\text { Commodity Prices: Implications for Indonesia }\end{array}$ & World Bank & Report & 2 \\
\hline $\begin{array}{l}\text { Goetz, Glauben \& } \\
\text { Brümmer, } 2010\end{array}$ & $\begin{array}{l}\text { How did policy interventions in wheat export markets in Russia and } \\
\text { Ukraine during the food crisis } 2007 / 2008 \text { influence world market } \\
\text { price transmission? }\end{array}$ & $\begin{array}{l}\text { IAMO, } U \text { of } \\
\text { Göttingen }\end{array}$ & Conference & 10 \\
\hline Robles \& Torero, 2010 & Understanding the Impact of High Food Prices in Latin America & ECONOMIA & Journal & 4 \\
\hline Araujo Enciso, 2009 & $\begin{array}{l}\text { Evidence of non-linear price transmission between maize markets in } \\
\text { Mexico and the US }\end{array}$ & U of Göttingen & Conference & 18 \\
\hline Bamuturaki, 2009 & $\begin{array}{l}\text { World market integration and price transmission in selected markets } \\
\text { in Tanzania }\end{array}$ & $U$ of Hohenheim & Thesis & 2 \\
\hline $\begin{array}{l}\text { Dutoit, Hernandez- } \\
\text { Villafuerte \& Urrutia, } \\
2009\end{array}$ & Price transmission in Latin American maize and rice markets & $\begin{array}{l}\text { UN ECLAC, } U \text { of } \\
\text { Göttingen }\end{array}$ & Report & 46 \\
\hline $\begin{array}{l}\text { Rapsomanikis et al., } \\
2009\end{array}$ & $\begin{array}{l}\text { The 2007-2008 Food Price Swing: Impact and policies in Eastern and } \\
\text { Southern Africa }\end{array}$ & FAO & Report & 42 \\
\hline World Bank, 2009 & $\begin{array}{l}\text { Eastern Africa: A study of the regional maize market and marketing } \\
\text { costs }\end{array}$ & $\begin{array}{l}\text { U of Göttingen, } \\
\text { World Bank }\end{array}$ & Report & 12 \\
\hline $\begin{array}{l}\text { Cudjoe, Breisinger \& } \\
\text { Diao, } 2008\end{array}$ & $\begin{array}{l}\text { Local impacts of a global crisis: food price transmission and poverty } \\
\text { impacts in Ghana }\end{array}$ & IFPRI & Report & 2 \\
\hline Ghoshray, 2008 & $\begin{array}{l}\text { Asymmetric Adjustment of Rice Export Prices: The Case of Thailand } \\
\text { and Vietnam }\end{array}$ & $\begin{array}{l}\text { International Journal } \\
\text { of Applied Economics }\end{array}$ & Journal & 5 \\
\hline $\begin{array}{l}\text { Imai, Gaiha \& Thapa, } \\
2008\end{array}$ & $\begin{array}{l}\text { Transmission of World Commodity Prices to Domestic Commodity } \\
\text { Prices in India and China }\end{array}$ & $\begin{array}{l}\text { Brooks World } \\
\text { Poverty Institute }\end{array}$ & Report & 12 \\
\hline Listorti \& Esposti, 2008 & $\begin{array}{l}\text { Making the world market price endogenous within AGMEMOD } \\
\text { modeling framework: an econometric solution }\end{array}$ & $\begin{array}{l}\text { Università } \\
\text { Politecnica delle } \\
\text { Marche }\end{array}$ & Conference & 1 \\
\hline Warr, 2008 & $\begin{array}{l}\text { The transmission of import prices to domestic prices: an application } \\
\text { to Indonesia }\end{array}$ & $\begin{array}{l}\text { Applied Economics } \\
\text { Letters }\end{array}$ & Journal & 3 \\
\hline Myint, 2007 & Myanmar rice market: market integration and price causality & Yezin Agricultural U & Thesis & 2 \\
\hline Reddy, 2006 & Commodity market integration: case of Asian rice markets & CSIRD & Report & 18 \\
\hline $\begin{array}{l}\text { Thomas \& Morrison, } \\
2006\end{array}$ & Trade reforms and food security: Country Case Studies and Synthesis & FAO & Report & 18 \\
\hline $\begin{array}{l}\text { Yavapolkul, Gopinath \& } \\
\text { Gulati, } 2006\end{array}$ & $\begin{array}{l}\text { Post-Uruguay Round price linkages between developed and } \\
\text { developing countries: the case of rice and wheat markets }\end{array}$ & $\begin{array}{l}\text { Agricultural } \\
\text { Economics }\end{array}$ & Journal & 4 \\
\hline Conforti, 2004 & Price transmission in selected agricultural markets & FAO & Report & 134 \\
\hline Sagidova, 2004 & Price transmission in grain market: case of Ukraine & $\begin{array}{l}\text { Kyiv-Mohyla } \\
\text { Academy }\end{array}$ & Thesis & 4 \\
\hline Baffes \& Gardner, 2003 & $\begin{array}{l}\text { The transmission of world commodity prices to domestic markets } \\
\text { under policy reforms in developing countries }\end{array}$ & $\begin{array}{l}\text { Journal of Policy } \\
\text { Reform }\end{array}$ & Journal & 44 \\
\hline Hai, 2003 & $\begin{array}{l}\text { Rice markets in the Mekong river delta, Vietnam: a market } \\
\text { integration analysis }\end{array}$ & $\begin{array}{l}\text { Centre for ASEAN } \\
\text { Studies }\end{array}$ & Report & 1 \\
\hline $\begin{array}{l}\text { Rapsomanikis et al., } \\
2003\end{array}$ & $\begin{array}{l}\text { Market integration and price transmission in selected food and cash } \\
\text { crop markets of developing countries: review and applications }\end{array}$ & FAO & Report & 3 \\
\hline Sharma, 2003 & $\begin{array}{l}\text { The transmission of world price signals: the concept, issues, and } \\
\text { some evidence from Asian cereal markets }\end{array}$ & OECD & Book & 16 \\
\hline Ghoshray, 2002 & Asymmetric Price Adjustment and the World Wheat Market & $\begin{array}{l}\text { Journal of } \\
\text { Agricultural } \\
\text { Economics }\end{array}$ & Journal & 180 \\
\hline $\begin{array}{l}\text { Mohanty, Smith \& } \\
\text { Peterson, } 1996\end{array}$ & $\begin{array}{l}\text { Time series evidence of relationships between U.S. and Canadian } \\
\text { wheat prices }\end{array}$ & lowa State University & Report & 8 \\
\hline
\end{tabular}


Appendix Table 2: Cointegration between international and domestic prices in the GIEWS dataset by product and country

\begin{tabular}{|c|c|c|c|c|c|c|c|c|c|c|c|c|c|c|c|c|c|c|}
\hline \multirow[b]{3}{*}{ Country } & \multicolumn{6}{|c|}{ Maize } & \multicolumn{6}{|c|}{ Rice } & \multicolumn{6}{|c|}{ Wheat } \\
\hline & \multicolumn{2}{|c|}{ entire period } & \multicolumn{2}{|c|}{ pre- break } & \multicolumn{2}{|c|}{ post- break } & \multicolumn{2}{|c|}{ entire period } & \multicolumn{2}{|c|}{ pre- break } & \multicolumn{2}{|c|}{ post- break } & \multicolumn{2}{|c|}{ entire period } & \multicolumn{2}{|c|}{ pre- break } & \multicolumn{2}{|c|}{ post- break } \\
\hline & $\begin{array}{c}\# \text { of } \\
\text { cointe } \\
\text { grated } \\
\text { pairs }\end{array}$ & $\begin{array}{c}\text { \# of } \\
\text { pairs }\end{array}$ & $\begin{array}{c}\text { \# of } \\
\text { cointe } \\
\text { grated } \\
\text { pairs }\end{array}$ & $\begin{array}{c}\text { \# of } \\
\text { pairs }\end{array}$ & \begin{tabular}{|c}
$\#$ of \\
cointe \\
grated \\
pairs
\end{tabular} & $\begin{array}{l}\text { \# of } \\
\text { pairs }\end{array}$ & $\begin{array}{c}\text { \# of } \\
\text { cointe } \\
\text { grated } \\
\text { pairs }\end{array}$ & $\begin{array}{c}\text { \# of } \\
\text { pairs }\end{array}$ & $\begin{array}{c}\text { \# of } \\
\text { cointe } \\
\text { grated } \\
\text { pairs }\end{array}$ & $\begin{array}{l}\text { \# of } \\
\text { pairs }\end{array}$ & \begin{tabular}{|c}
$\#$ of \\
cointe \\
grated \\
pairs
\end{tabular} & $\begin{array}{l}\text { \# of } \\
\text { pairs }\end{array}$ & $\begin{array}{c}\text { \# of } \\
\text { cointe } \\
\text { grated } \\
\text { pairs }\end{array}$ & $\begin{array}{l}\text { \# of } \\
\text { pairs }\end{array}$ & $\begin{array}{c}\text { \# of } \\
\text { cointe } \\
\text { grated } \\
\text { pairs }\end{array}$ & $\begin{array}{l}\text { \# of } \\
\text { pairs }\end{array}$ & $\begin{array}{c}\text { \# of } \\
\text { cointe } \\
\text { grated } \\
\text { pairs }\end{array}$ & $\begin{array}{l}\text { \# of } \\
\text { pairs }\end{array}$ \\
\hline Afghanistan & & & & & & & & & & & & & 3 & 4 & 0 & 4 & 2 & 4 \\
\hline Argentina & 1 & 1 & 0 & 1 & 1 & 1 & & & & & & & 0 & 3 & 0 & 3 & 0 & 3 \\
\hline Bangladesh & & & & & & & & & & & & & 0 & 4 & 0 & 3 & 0 & 4 \\
\hline Benin & 7 & 7 & 5 & 7 & 2 & 7 & 4 & 4 & 3 & 4 & 1 & 4 & & & & & & \\
\hline Bhutan & & & & & & & 1 & 2 & & & 1 & 2 & 0 & 1 & & & 0 & 1 \\
\hline Bolivia & 1 & 3 & 1 & 3 & 1 & 3 & 4 & 6 & 0 & 6 & 4 & 6 & 0 & 3 & 0 & 3 & 0 & 3 \\
\hline Brazil & 1 & 2 & 0 & 2 & 0 & 2 & 3 & 5 & 0 & 5 & 0 & 5 & 1 & 2 & 0 & 2 & 0 & 2 \\
\hline Burkina Faso & & & & & & & 8 & 9 & 0 & 3 & 8 & 9 & & & & & & \\
\hline Burundi & 0 & 1 & 0 & 1 & 0 & 1 & 0 & 1 & 0 & 1 & 0 & 1 & 0 & 1 & 0 & 1 & 0 & 1 \\
\hline Cambodia & & & & & & & 0 & 4 & 0 & 3 & 1 & 4 & & & & & & \\
\hline Cameroon & 0 & 5 & 0 & 5 & 0 & 5 & 5 & 5 & 2 & 5 & 4 & 5 & & & & & & \\
\hline Cape Verde & 1 & 9 & 0 & 3 & 2 & 9 & 2 & 6 & 2 & 6 & 0 & 6 & & & & & & \\
\hline Chad & 1 & 3 & 0 & 3 & 3 & 3 & 3 & 3 & 2 & 3 & 2 & 3 & & & & & & \\
\hline China & & & & & & & 0 & 2 & 1 & 2 & 0 & 2 & & & & & & \\
\hline Colombia & 3 & 3 & 0 & 3 & 1 & 3 & 4 & 5 & 0 & 5 & 5 & 5 & & & & & & \\
\hline Costa Rica & 0 & 2 & 0 & 1 & 0 & 2 & 0 & 2 & 0 & 2 & 0 & 2 & & & & & & \\
\hline D.R. Congo & 0 & 3 & & & 0 & 3 & 2 & 4 & & & 2 & 4 & & & & & & \\
\hline Djibouti & & & & & & & 2 & 2 & 1 & 2 & 1 & 2 & & & & & & \\
\hline Dominican Republic & 0 & 2 & 0 & 2 & 1 & 2 & 3 & 4 & 2 & 4 & 4 & 4 & & & & & & \\
\hline Ecuador & 2 & 8 & 2 & 8 & 0 & 8 & 4 & 9 & 0 & 9 & 3 & 9 & & & & & & \\
\hline Egypt & 0 & 4 & & & 0 & 4 & 2 & 4 & & & 2 & 4 & 0 & 2 & & & 0 & 2 \\
\hline El Salvador & 0 & 2 & 1 & 2 & 0 & 2 & 2 & 2 & 0 & 2 & 2 & 2 & & & & & & \\
\hline
\end{tabular}

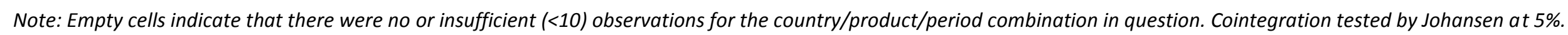


Appendix Table 2: Cointegration between international and domestic prices in the GIEWS dataset by product and country (continued)

\begin{tabular}{|c|c|c|c|c|c|c|c|c|c|c|c|c|c|c|c|c|c|c|}
\hline \multirow[b]{3}{*}{ Country } & \multicolumn{6}{|c|}{ Maize } & \multicolumn{6}{|c|}{ Rice } & \multicolumn{6}{|c|}{ Wheat } \\
\hline & \multicolumn{2}{|c|}{ entire period } & \multicolumn{2}{|c|}{ pre- break } & \multicolumn{2}{|c|}{ post- break } & \multicolumn{2}{|c|}{ entire period } & \multicolumn{2}{|c|}{ pre- break } & \multicolumn{2}{|c|}{ post- break } & \multicolumn{2}{|c|}{ entire period } & \multicolumn{2}{|c|}{ pre- break } & \multicolumn{2}{|c|}{ post- break } \\
\hline & $\begin{array}{l}\text { \# of } \\
\text { cointe } \\
\text { grated } \\
\text { pairs } \\
\end{array}$ & $\begin{array}{l}\text { \# of } \\
\text { pairs }\end{array}$ & \begin{tabular}{|c} 
\# of \\
cointe \\
grated \\
pairs \\
\end{tabular} & $\begin{array}{l}\text { \# of } \\
\text { pairs }\end{array}$ & $\begin{array}{c}\text { \# of } \\
\text { cointe } \\
\text { grated } \\
\text { pairs }\end{array}$ & $\begin{array}{l}\text { \# of } \\
\text { pairs }\end{array}$ & \begin{tabular}{|c|} 
\# of \\
cointe \\
grated \\
pairs \\
\end{tabular} & $\begin{array}{l}\text { \# of } \\
\text { pairs }\end{array}$ & $\begin{array}{l}\text { \# of } \\
\text { cointe } \\
\text { grated } \\
\text { pairs }\end{array}$ & $\begin{array}{l}\text { \# of } \\
\text { pairs }\end{array}$ & $\begin{array}{c}\text { \# of } \\
\text { cointe } \\
\text { grated } \\
\text { pairs }\end{array}$ & $\begin{array}{l}\text { \# of } \\
\text { pairs }\end{array}$ & $\begin{array}{l}\text { \# of } \\
\text { cointe } \\
\text { grated } \\
\text { pairs } \\
\end{array}$ & $\begin{array}{l}\# \text { of } \\
\text { pairs }\end{array}$ & $\begin{array}{l}\text { \# of } \\
\text { cointe } \\
\text { grated } \\
\text { pairs } \\
\end{array}$ & $\begin{array}{l}\text { \# of } \\
\text { pairs }\end{array}$ & $\begin{array}{l}\text { \# of } \\
\text { cointe } \\
\text { grated } \\
\text { pairs }\end{array}$ & $\begin{array}{l}\text { \# of } \\
\text { pairs }\end{array}$ \\
\hline Eritrea & & & & & & & & & & & & & 1 & 1 & & & 0 & 1 \\
\hline Ethiopia & 1 & 8 & 0 & 4 & 4 & 8 & & & & & & & 7 & 11 & 2 & 11 & 7 & 11 \\
\hline Gabon & & & & & & & 0 & 1 & & & 0 & 1 & & & & & & \\
\hline Ghana & 0 & 3 & 0 & 3 & 0 & 3 & 0 & 2 & 0 & 2 & 0 & 2 & & & & & & \\
\hline Guatemala & 3 & 3 & 1 & 3 & 3 & 3 & 2 & 3 & 0 & 2 & 1 & 3 & & & & & & \\
\hline Guinea & & & & & & & 0 & 2 & & & 1 & 2 & & & & & & \\
\hline Haiti & 1 & 14 & 2 & 14 & 1 & 14 & 3 & 14 & 2 & 13 & 1 & 14 & & & & & & \\
\hline Honduras & 3 & 3 & 0 & 1 & 1 & 3 & 2 & 2 & & & 2 & 2 & & & & & & \\
\hline India & & & & & & & 2 & 8 & 2 & 8 & 2 & 8 & 0 & 8 & 0 & 8 & 0 & 8 \\
\hline Indonesia & & & & & & & 1 & 1 & & & 1 & 1 & & & & & & \\
\hline Israel & 0 & 1 & 0 & 1 & 0 & 1 & & & & & & & 0 & 1 & 0 & 1 & 0 & 1 \\
\hline Kenya & 0 & 6 & 1 & 5 & 1 & 6 & & & & & & & & & & & & \\
\hline Lao People's Dem. Rep. & & & & & & & 1 & 3 & 1 & 3 & 0 & 3 & & & & & & \\
\hline Lesotho & & & & & & & 0 & 1 & & & 0 & 1 & & & & & & \\
\hline Madagascar & & & & & & & 0 & 2 & 0 & 2 & 0 & 2 & & & & & & \\
\hline Malawi & 0 & 6 & & & 2 & 6 & 0 & 2 & & & 0 & 2 & & & & & & \\
\hline Mali & & & & & & & 11 & 14 & 0 & 4 & 11 & 14 & & & & & & \\
\hline Mauritania & & & & & & & 0 & 1 & 0 & 1 & 0 & 1 & 0 & 1 & & & 0 & 1 \\
\hline Mexico & 4 & 5 & 2 & 5 & 2 & 5 & 1 & 4 & 0 & 4 & 3 & 4 & & & & & & \\
\hline Mongolia & & & & & & & 0 & 1 & & & 0 & 1 & & & & & & \\
\hline Mozambique & 11 & 14 & 9 & 14 & 5 & 13 & 8 & 10 & 2 & 10 & 4 & 10 & & & & & & \\
\hline
\end{tabular}

Note: Empty cells indicate that there were no or insufficient $(<10)$ observations for the country/product/period combination in question. Cointegration tested by Johansen at $5 \%$.

ज 
Appendix Table 2: Cointegration between international and domestic prices in the GIEWS dataset by product and country (continued)

\begin{tabular}{|c|c|c|c|c|c|c|c|c|c|c|c|c|c|c|c|c|c|c|}
\hline \multirow[b]{3}{*}{ Country } & \multicolumn{6}{|c|}{ Maize } & \multicolumn{6}{|c|}{ Rice } & \multicolumn{6}{|c|}{ Wheat } \\
\hline & \multicolumn{2}{|c|}{ entire period } & \multicolumn{2}{|c|}{ pre- break } & \multicolumn{2}{|c|}{ post- break } & \multicolumn{2}{|c|}{ entire period } & \multicolumn{2}{|c|}{ pre- break } & \multicolumn{2}{|c|}{ post- break } & \multicolumn{2}{|c|}{ entire period } & \multicolumn{2}{|c|}{ pre- break } & \multicolumn{2}{|c|}{ post- break } \\
\hline & $\begin{array}{c}\text { \# of } \\
\text { cointe } \\
\text { grated } \\
\text { pairs } \\
\end{array}$ & $\begin{array}{l}\text { \# of } \\
\text { pairs }\end{array}$ & $\begin{array}{c}\text { \# of } \\
\text { cointe } \\
\text { grated } \\
\text { pairs } \\
\end{array}$ & $\begin{array}{l}\text { \# of } \\
\text { pairs }\end{array}$ & $\begin{array}{c}\text { \# of } \\
\text { cointe } \\
\text { grated } \\
\text { pairs } \\
\end{array}$ & $\begin{array}{l}\text { \# of } \\
\text { pairs }\end{array}$ & $\begin{array}{c}\text { \# of } \\
\text { cointe } \\
\text { grated } \\
\text { pairs }\end{array}$ & $\begin{array}{l}\text { \# of } \\
\text { pairs }\end{array}$ & $\begin{array}{c}\text { \# of } \\
\text { cointe } \\
\text { grated } \\
\text { pairs } \\
\end{array}$ & $\begin{array}{l}\text { \# of } \\
\text { pairs }\end{array}$ & $\begin{array}{c}\text { \# of } \\
\text { cointe } \\
\text { grated } \\
\text { pairs } \\
\end{array}$ & $\begin{array}{l}\text { \# of } \\
\text { pairs }\end{array}$ & $\begin{array}{c}\# \text { of } \\
\text { cointe } \\
\text { grated } \\
\text { pairs } \\
\end{array}$ & $\begin{array}{l}\text { \# of } \\
\text { pairs }\end{array}$ & $\begin{array}{c}\text { \# of } \\
\text { cointe } \\
\text { grated } \\
\text { pairs } \\
\end{array}$ & $\begin{array}{l}\text { \# of } \\
\text { pairs }\end{array}$ & $\begin{array}{c}\text { \# of } \\
\text { cointe } \\
\text { grated } \\
\text { pairs } \\
\end{array}$ & $\begin{array}{l}\text { \# of } \\
\text { pairs }\end{array}$ \\
\hline Myanmar & & & & & & & 1 & 1 & & & 1 & 1 & & & & & & \\
\hline Namibia & 0 & 1 & & & 0 & 1 & & & & & & & & & & & & \\
\hline Nicaragua & 3 & 6 & 3 & 5 & 2 & 6 & 10 & 10 & 1 & 8 & 10 & 10 & & & & & & \\
\hline Niger & 0 & 6 & 0 & 6 & 2 & 6 & 9 & 12 & 5 & 12 & 6 & 12 & & & & & & \\
\hline Nigeria & 0 & 1 & 0 & 1 & 0 & 1 & & & & & & & & & & & & \\
\hline Pakistan & & & & & & & 0 & 5 & 2 & 5 & 1 & 5 & 0 & 4 & 0 & 4 & 4 & 4 \\
\hline Panama & 0 & 2 & 0 & 2 & 0 & 2 & 1 & 2 & 1 & 2 & 2 & 2 & & & & & & \\
\hline Peru & 0 & 2 & 0 & 2 & 0 & 2 & 0 & 1 & 0 & 1 & 0 & 1 & 1 & 2 & 0 & 2 & 0 & 2 \\
\hline Philippines & 2 & 8 & 0 & 8 & 0 & 8 & 6 & 28 & 19 & 28 & 2 & 28 & & & & & & \\
\hline Republic of Moldova & 0 & 2 & & & 0 & 2 & & & & & & & & & & & & \\
\hline Russian Federation & 0 & 1 & 0 & 1 & 0 & 1 & 1 & 1 & 0 & 1 & 0 & 1 & 0 & 1 & & & 0 & 1 \\
\hline Rwanda & 1 & 1 & 0 & 1 & 1 & 1 & 1 & 1 & 0 & 1 & 1 & 1 & & & & & & \\
\hline Samoa & & & & & & & & & 0 & 1 & & & & & & & & \\
\hline Senegal & & & & & & & 9 & 11 & & & 8 & 11 & & & & & & \\
\hline Somalia & 6 & 11 & 0 & 10 & 5 & 11 & 9 & 12 & 6 & 11 & 3 & 12 & & & & & & \\
\hline South Africa & 0 & 1 & 1 & 2 & 0 & 2 & & & & & & & 0 & 1 & 0 & 1 & 0 & 1 \\
\hline Sri Lanka & & & & & & & 1 & 1 & 0 & 1 & 1 & 1 & & & & & & \\
\hline Sudan & & & & & & & & & & & & & 1 & 5 & 0 & 5 & 2 & 5 \\
\hline Thailand & 0 & 1 & 0 & 1 & 0 & 1 & 1 & 1 & 1 & 1 & 0 & 1 & & & & & & \\
\hline Timor-Leste & 0 & 1 & & & 0 & 1 & 1 & 1 & & & 1 & 1 & & & & & & \\
\hline Togo & 0 & 6 & 0 & 6 & 2 & 6 & 4 & 6 & 1 & 6 & 2 & 6 & & & & & & \\
\hline Tunisia & & & & & & & 1 & 1 & 1 & 1 & 1 & 1 & & & & & & \\
\hline
\end{tabular}

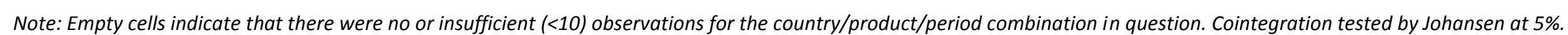

ज 
Appendix Table 2: Cointegration between international and domestic prices in the GIEWS dataset by product and country (continued)

\begin{tabular}{|c|c|c|c|c|c|c|c|c|c|c|c|c|c|c|c|c|c|c|}
\hline \multirow[b]{3}{*}{ Country } & \multicolumn{6}{|c|}{ Maize } & \multicolumn{6}{|c|}{ Rice } & \multicolumn{6}{|c|}{ Wheat } \\
\hline & \multicolumn{2}{|c|}{ entire period } & \multicolumn{2}{|c|}{ pre- break } & \multicolumn{2}{|c|}{ post- break } & \multicolumn{2}{|c|}{ entire period } & \multicolumn{2}{|c|}{ pre- break } & \multicolumn{2}{|c|}{ post- break } & \multicolumn{2}{|c|}{ entire period } & \multicolumn{2}{|c|}{ pre- break } & \multicolumn{2}{|c|}{ post- break } \\
\hline & $\begin{array}{c}\text { \# of } \\
\text { cointe } \\
\text { grated } \\
\text { pairs } \\
\end{array}$ & $\begin{array}{l}\text { \# of } \\
\text { pairs }\end{array}$ & $\begin{array}{l}\text { \# of } \\
\text { cointe } \\
\text { grated } \\
\text { pairs }\end{array}$ & $\begin{array}{l}\# \text { of } \\
\text { pairs }\end{array}$ & $\begin{array}{c}\text { \# of } \\
\text { cointe } \\
\text { grated } \\
\text { pairs }\end{array}$ & $\begin{array}{l}\text { \# of } \\
\text { pairs }\end{array}$ & $\begin{array}{l}\text { \# of } \\
\text { cointe } \\
\text { grated } \\
\text { pairs }\end{array}$ & $\begin{array}{l}\text { \# of } \\
\text { pairs }\end{array}$ & $\begin{array}{l}\text { \# of } \\
\text { cointe } \\
\text { grated } \\
\text { pairs }\end{array}$ & $\begin{array}{l}\# \text { of } \\
\text { pairs }\end{array}$ & $\begin{array}{l}\text { \# of } \\
\text { cointe } \\
\text { grated } \\
\text { pairs }\end{array}$ & $\begin{array}{l}\text { \# of } \\
\text { pairs }\end{array}$ & $\begin{array}{l}\text { \# of } \\
\text { cointe } \\
\text { grated } \\
\text { pairs }\end{array}$ & $\begin{array}{l}\# \text { of } \\
\text { pairs }\end{array}$ & $\begin{array}{l}\text { \# of } \\
\text { cointe } \\
\text { grated } \\
\text { pairs }\end{array}$ & $\begin{array}{l}\# \text { of } \\
\text { pairs }\end{array}$ & $\begin{array}{c}\text { \# of } \\
\text { cointe } \\
\text { grated } \\
\text { pairs }\end{array}$ & $\begin{array}{l}\text { \# of } \\
\text { pairs }\end{array}$ \\
\hline Uganda & 0 & 3 & 0 & 1 & 1 & 2 & 2 & 3 & 0 & 3 & 2 & 3 & & & & & & \\
\hline Ukraine & 1 & 1 & 0 & 1 & 1 & 1 & & & & & & & 0 & 1 & 0 & 1 & 0 & 1 \\
\hline United Rep. of Tanzania & 2 & 5 & 1 & 1 & 3 & 5 & & & & & & & & & & & & \\
\hline Uruguay & & & & & & & 0 & 1 & & & 0 & 1 & 0 & 1 & 0 & 1 & 0 & 1 \\
\hline Vietnam & & & & & & & 1 & 1 & & & 0 & 1 & & & & & & \\
\hline Zambia & 0 & 1 & 0 & 1 & 0 & 1 & 0 & 1 & & & 0 & 1 & & & & & & \\
\hline Zimbabwe & 0 & 1 & 1 & 1 & 0 & 1 & & & & & & & & & & & & \\
\hline Sum & 55 & 179 & 30 & 141 & 47 & 178 & 139 & 251 & 57 & 193 & 108 & 251 & 14 & 57 & 2 & 50 & 15 & 57 \\
\hline $\begin{array}{l}\text { Share of cointegrated } \\
\text { pairs }\end{array}$ & 30. & & 21.3 & & 26. & & 55.4 & & 29.5 & & 43.0 & & 24.6 & & 4.0 & & 26. & \\
\hline
\end{tabular}

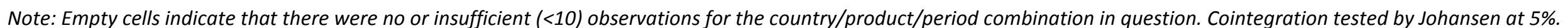


Appendix Table 3: Average estimates of the long-run PT coefficient $\beta$ taken from the literature and GIEWS samples, by product and region. Comparison only includes those product/country combinations for which there are observations in both the GIEWS and literature samples.

\begin{tabular}{l|c|c|c|c|c|c|c|c}
\hline & \multicolumn{2}{|c|}{ Maize } & \multicolumn{2}{c|}{ Rice } & \multicolumn{2}{c|}{ Wheat } & \multicolumn{2}{c}{ All three cereals } \\
\cline { 2 - 9 } & GIEWS & Lit. & GIEWS & Lit. & GIEWS & Lit. & GIEWS & Lit. \\
\hline Asia \& ME & 0.90 & 1.03 & 0.31 & 0.60 & 1.51 & 0.11 & 0.60 & 0.59 \\
E. Africa & 0.85 & 0.84 & 1.28 & 0.58 & 1.04 & 0.65 & 0.98 & 0.80 \\
W. Africa & 1.62 & 1.74 & 0.52 & 0.40 & - & - & 0.63 & 0.59 \\
L. America & 0.70 & - & 0.73 & 0.62 & 0.95 & - & 0.74 & 0.62 \\
\hline All regions & 0.85 & 0.86 & 0.56 & 0.59 & 1.24 & 0.43 & 0.75 & 0.69 \\
\hline
\end{tabular}

Note: Averages by region and cereal weighted by the number of observations in each category.

Source: Own calculations with literature sample and GIEWS price data.

Appendix Table 4: Average estimates of the adjustment parameter $\alpha$ taken from the literature and GIEWS samples, by product and region. Comparison only includes those product/country combinations for which there are observations in both the GIEWS and literature samples.

\begin{tabular}{l|c|c|c|c|c|c|c|c}
\hline & \multicolumn{2}{|c|}{ Maize } & \multicolumn{2}{c|}{ Rice } & \multicolumn{2}{c|}{ Wheat } & \multicolumn{2}{c}{ All three cereals } \\
\cline { 2 - 8 } & GIEWS & Lit. & GIEWS & Lit. & GIEWS & Lit. & GIEWS & Lit. \\
\hline Asia \& ME & -0.07 & 0.10 & -0.02 & -0.12 & -0.02 & -0.07 & -0.03 & -0.12 \\
E. Africa & -0.12 & -0.09 & -0.09 & -0.06 & -0.15 & -0.25 & -0.12 & -0.10 \\
W. Africa & -0.26 & -0.10 & -0.15 & -0.14 & & & -0.16 & -0.13 \\
L. America & -0.16 & & -0.07 & -0.34 & -0.12 & & -0.11 & -0.34 \\
\hline All regions & -0.13 & -0.09 & -0.07 & -0.22 & -0.09 & -0.18 & -0.09 & -0.17 \\
\hline
\end{tabular}

Note: Averages by region and cereal weighted by the number of observations in each category.

Source: Own calculations with literature sample and GIEWS price data.

Appendix Table 5: Countries with state trading enterprises (STEs) for maize, rice or wheat

\begin{tabular}{l|l}
\hline Product & Countries with STEs \\
\hline Maize & China, Kenya, Malawi, Zambia, Zimbabwe \\
\hline Rice & $\begin{array}{l}\text { Australia, China, Dominican Republic, India, Iraq, Japan, Kenya, Korea, Malaysia, } \\
\text { Pakistan, Philippines, Thailand, Vietnam }\end{array}$ \\
\hline Wheat & $\begin{array}{l}\text { Australia, Canada, China, Cyprus, Egypt, Arab Rep., India, Iran, Japan, Korea, } \\
\text { Pakistan, Sri Lanka, Sudan, Syria, Tajikistan, Tunisia }\end{array}$ \\
\hline
\end{tabular}

Source: Compiled using Ackerman (1997; 1998), Ackerman and Dixit (1999), Chang and de Gorter (2004), OECD (2007), Young (1999) and Young and Abbott (1998). 
Appendix Table 6: Numbers and shares of cases in which the adjustment parameter for the international price is significant

\begin{tabular}{l|c|c|c|c}
\hline $\begin{array}{l}\text { Product and } \\
\text { Market level }\end{array}$ & Number of series & $\begin{array}{c}\text { Number of cases } \\
\text { in which } \mathbf{P}_{\mathrm{INT}} \\
\text { reacts to } \\
\text { Of which } \\
\text { cointegrated }\end{array}$ & $\begin{array}{c}\text { Of which in the } \\
\text { appropriate } \\
\text { disequilibrium }\left(\boldsymbol{\alpha}_{2}\right. \\
\text { significant) }\end{array}$ & direction $\left(\boldsymbol{\alpha}_{2}>\mathbf{0}\right)$ \\
\hline Maize wholesale & 71 & $29(41)$ & $6(8)$ & $4(6)$ \\
Maize retail & 109 & $26(24)$ & $3(3)$ & $2(2)$ \\
\hline Wheat wholesale & 26 & $4(15)$ & $0(0)$ & $0(0)$ \\
Wheat retail & 31 & $10(32)$ & $1(3)$ & $0(0)$ \\
\hline Rice wholesale & 97 & $53(55)$ & $46(47)$ & $41(42)$ \\
Rice retail & 165 & $86(52)$ & $65(39)$ & $63(38)$ \\
\hline Total & 499 & $208(42)$ & $121(24)$ & $110(22)$ \\
\hline
\end{tabular}

Note: Number in brackets is the share of the corresponding number of series, in \%.

Source: Own calculations with GIEWS price data.

Appendix Figure 1: The prevalence of different international maize prices in the literature sample

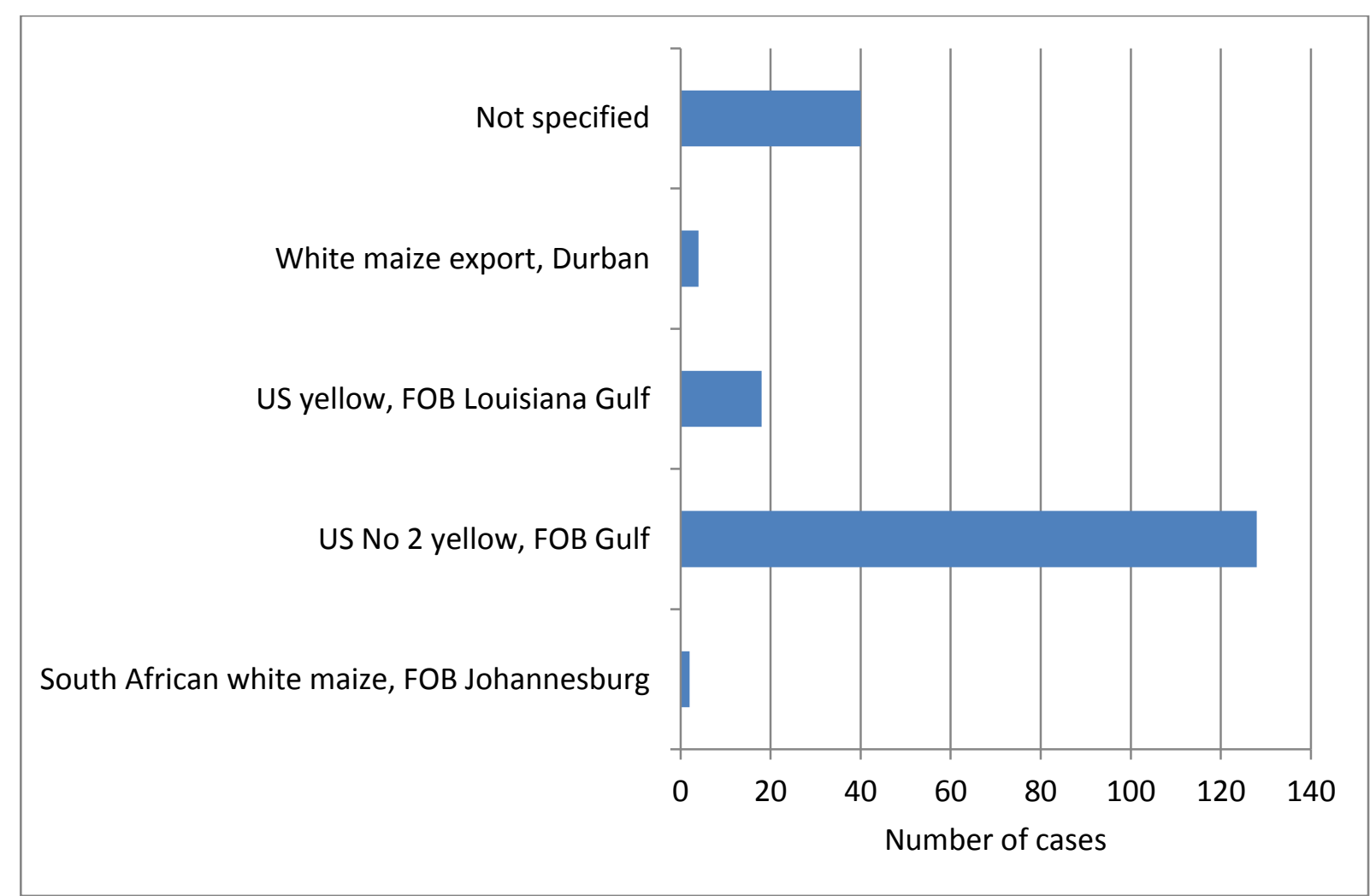

Source: Own calculations with literature sample. 
Appendix Figure 2: The prevalence of different international rice prices in the literature sample

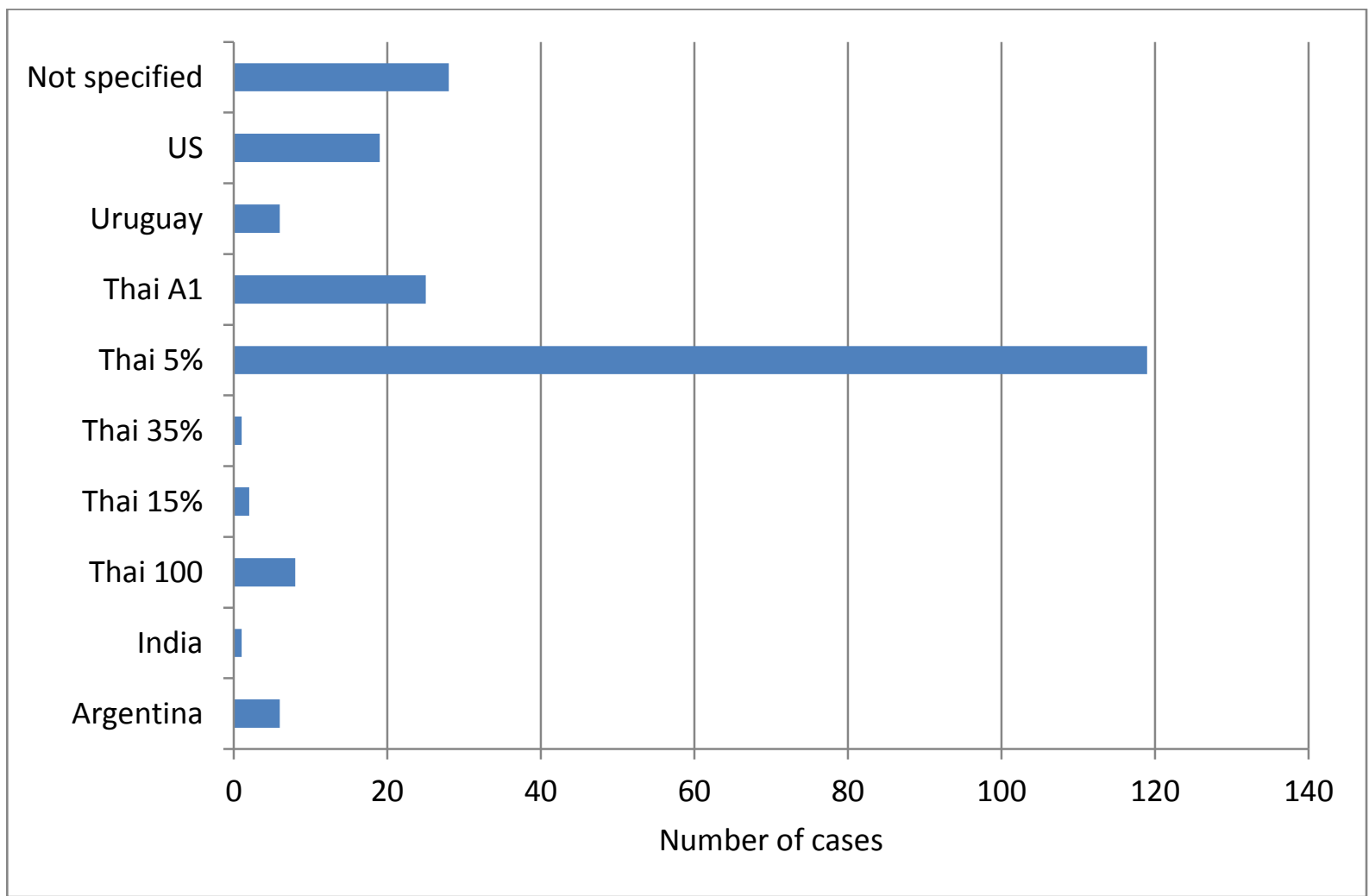

Source: Own calculations with literature sample.

Appendix Figure 3: The prevalence of different international wheat prices in the literature sample

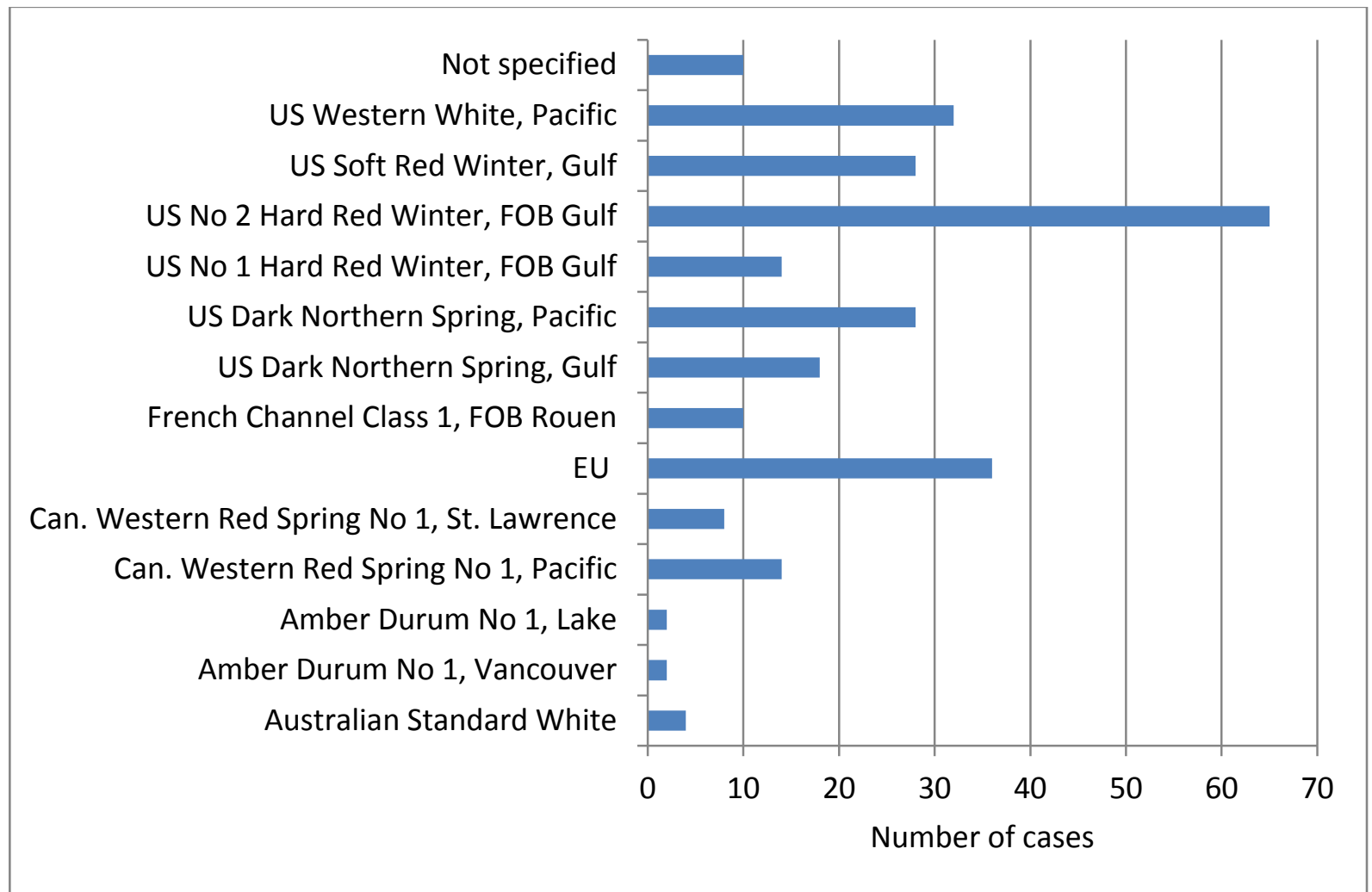

Source: Own calculations with literature sample. 
Chapter Two 


\title{
Distance and border effects on price transmission- a meta-analysis
}

\author{
Carolin Mengel, Stephan von Cramon-Taubadel ${ }^{13}$ \\ Department of Agricultural Economics and Rural Development \\ University of Göttingen
}

This paper is publicly available as GlobalFood Discussion Paper No. 37 on:

http://www.uni-goettingen.de/de/globalfood-discussion-paper-series/213486.html

\footnotetext{
${ }^{13}$ Corresponding authors: Carolin Mengel (carolin.mengel@agr.uni-goettingen.de), Stephan von CramonTaubadel (scramon@gwdg.de). Carolin Mengel is a Research Associate with the GlobalFood Research Training Group and gratefully acknowledges funding by the German Research Foundation (DFG). Stephan von CramonTaubadel is a professor holding the chair of Agricultural Policy at the Georg-August-University of Göttingen, Germany. We gratefully acknowledge the funding provided by the German Research Foundation (DFG). The authors thank Malte Ehrich, Christiane Wuckel and Sebastian Schramm for valuable research assistance.
} 


\begin{abstract}
In a meta-analysis of spatial price transmission (PT) literature we aim to test for the presence of distance and border effects on price transmission. We use PT estimates for 1189 cereal market pairs extracted from 57 studies and seek to explain them by airline distance and existence of a border. The findings indicate distance and border effects on both price cointegration and price transmission. A border separating two markets reduces the probability of cointegration of price series by $23 \%$ compared with markets located in the same country. 1000 kilometers of distance reduces the probability of cointegration by $7 \%$. The speed of price adjustment is on average $13 \%$ slower in international than in intra-national market pairs. 1000 kilometers of distance within a country on average yields 6-20\% slower price adjustment. Distance effects become negligible and economically insignificant for international market pairs. Maize price pairs are less often cointegrated compared to rice prices and cointegration is most prevalent for barley. Price transmission is slowest in wheat markets. In peer reviewed studies cointegration is more prevalent and price transmission is faster. However the explanation need not be a publication bias but can also result from higher quality methodologies. Moreover, we identify a set of model specifications that significantly affect price transmission estimates. The study contributes to the literature by presenting a first meta-analysis of spatial PT literature and providing insights into distance and border effects on price transmission.
\end{abstract}

JEL:

C32, L11, Q11, Q17

\title{
Keywords:
}

meta-analysis, cointegration, spatial price transmission, distance, borders, developing countries, agricultural trade, cereals, rice, maize, wheat 


\section{Introduction}

After international food price spikes in 2007-2008 and 2010-2011 (FAO et al., 2011), the transmission of price changes to domestic markets has attracted a great deal of attention in agricultural economics (Conforti, 2004; Cudjoe et al., 2010; Greb et al., 2012; Minot, 2011). The field of price transmission (PT) analysis has been analyzing food price dynamics between markets or market levels for much longer. In the past three decades, a vast literature has concerned itself with the modelling of price changes and price equilibria. An recent online search with the keywords "price transmission" in the database AgEcon-Search ${ }^{14}$ resulted in 403 hits. The abundance of empirical work has triggered a number of meta-analyses on vertical price transmission, i.e. between different market levels (Amikuzuno \& Ogundari, 2013; Bakucs et al., 2013; Greb et al., 2012). So far, no one has attempted to apply a similar approach to spatial price transmission studies to draw some general conclusions on its determinants. In line with theoretical and empirical approaches on distance and border effects in the trade and price literature we seek to shed light on distance and border effects. This is the first study employing a meta-analysis of the empirical spatial price transmission literature to test whether geographic distance and borders have a systematic effect on the strength and speed of PT. The intuitive hypothesis that we wish to test is that PT is weaker and slower over longer distances and across borders.

Our meta-analysis is limited to studies on main staple cereals such as rice, wheat and maize for a number of reasons. Cereals are relatively homogeneous goods for which quality differences play a much smaller role in PT than that for, e.g. fresh fruit and vegetables. The latter two are also more perishable, while cereals can be traded widely and internationally in large volumes and over long distances. The three main staple products rice, maize and wheat account for the largest shares of food trade worldwide and are thus economically significant products. Particularly in developing countries, cereals account for a large share of agricultural value-added (Rashid, 2011). Overall this has resulted in a large literature on PT between cereal markets that are separated by a wide range of distances both with and without international borders. This provides a rich dataset with which to test the effect of distance and borders on the PT after controlling for other potential determinants.

We find evidence of statistically and economically significant distance and border effects on PT. These findings contribute to the literature by providing further insights into the influence of different components of trade costs, which are related to crossing a border or trading over longer distances, on price transmission. The rest of this paper is structured as follows. Section 2 describes the theory of price transmission and the theoretical link to distances and borders. Section 3 presents the methods that we use to generate and analyze our meta-dataset. Section 4 presents the data and the estimation and in section 5 the results are shown. Section 6 concludes.

\section{Theory}

The toolbox of price transmission analysis offers a number of useful analytical applications to improve our understanding of price behavior. Whether and how price changes are transmitted to markets in other locations, or to goods or up- or downstream in the marketing chain can help assess the functioning, efficiency and integration of agri-food markets. In developing countries, food prices play an important role for both producers and consumers. The agricultural sector typically accounts for a large share of employment and income in rural areas. Efficient price signals between markets influence production and trade decisions. For consumers food prices determine their access to food, which often accounts for a large share of the household budget. Consequently price shocks can have important welfare effects. For policy makers the subject of price transmission is highly relevant as it may be helpful for the assessment of political decisions such as policy reforms and market

\footnotetext{
${ }^{14}$ http://ageconsearch.umn.edu, accessed on May 20, 2014
} 
liberalization measures (Abdulai, 2006). Information about the transmission of prices can also help in assessing the depth of regional integration or the functioning of trade agreements with regard to single commodities. The knowledge of market performance and efficiency is relevant in order to avoid inefficiencies and to assess the capacity of markets to absorb and buffer shocks. Physical barriers and large distances can result in high transport and transaction costs and hinder market integration. A lack of market integration can also result from political barriers in the context of trade policies and red tape and thus point to a need for corresponding policy reforms. The knowledge of price mechanisms reduces uncertainty for policy-makers and the risk of duplication of interventions in two markets (Goletti et al., 1995).

According to the law of one price, price differences for similar products in different locations are reduced by spatial arbitrage until they amount to no more than the transfer costs. Price transmission analysis helps to assess how closely prices in two markets are linked to each other in the long run. In addition, the nature and level of price reactions indicate market integration and "the extent to which markets function efficiently" (Rapsomanikis et al., 2006). Empirical PT analysis provides insights into the price dynamics between two markets: if and when prices are linked together in a long-run equilibrium, and whether and how quickly deviations or price shocks are transmitted so as to restore this equilibrium.

Many PT studies confirm that trade costs influence price transmission. The model that is currently most commonly used to study spatial price transmission, the threshold vector error correction model (TVECM, see Greb et al., 2013) includes a threshold parameter that is introduced to reflect the magnitude of trade costs between two markets. Nevertheless, only few PT studies have explicitly studied the effect of distance and borders on price transmission (Hernandez-Villafuerte, 2011; Ihle et al., 2011). Ihle et al. (2011), in a study of maize price transmission in Eastern Africa, find evidence for distance and border effects. They estimate the speed of price transmission for 85 pairs of markets and regress these speeds on the geographic distance between the markets and a set of borderspecific dummy variables. While distance has a nonlinear and statistically significant effect on the speed of price transmission, border effects are heterogeneous and vary with differences in trade policies employed by the countries. Amikuzuno \& Donkoh (2012) look at border effects in tomato trade between Ghana and Burkina-Faso and model trade flows with a regime-switching model that includes a cross-border regime and a domestic trade regime. They find that PT is more rapid in the domestic trade regime and attribute this to a negative border effect.

Some studies in the trade literature provide more theoretical and empirical research on distance and border effects. Empirical trade volume studies have found that borders and distance have a strong inhibiting effect on trade flows. Interprovincial trade within Canada or within the U.S. is more than twenty times higher than across the U.S.-Canadian border, controlling for distance and the size of the markets (provinces) (McCallum, 1995). Standard gravity models thus include distance as one of the explanatory variables for trade, together with other factors such as common language, history or economic development. The effects of distance and borders on price disparities between spatially separated markets also has been subject to empirical analyses. The seminal work of Engel and Rogers (1995) shows the effect of an international border and inter-market distance on differences in real consumer prices in cities on both sides along the U.S.-Canadian border. Their results indicate that a border separating two markets has the same effect as 2500 miles of distance between them. Aker et al. (2013) find borders and ethnicities play a major role for staple price disparities in Niger. Additional transaction costs associated with crossing a border increase price disparities by 17 to 26 percent.

We follow these findings and employ a trade cost approach (Anderson \& Van Wincoop, 2004). It is empirically established that high trade cost are associated with lower trade volumes. Trade due to spatial arbitrage is an important driver of spatial price transmission. If trade volumes fall due to distance and borders, then we might expect spatial price transmission to become weaker as well, all other things being equal. This theoretical link leads to the research question whether high trade cost influence price transmission via reduced trade. 
Trade cost are comprised of transaction costs, transport costs and policy barriers. Transport costs vary with the means of transport and include the costs of fuel/energy, losses due to the perishability of the traded product, transport time and in some settings bribery. Policy barriers include tariffs, custom procedures, compliance costs, price policies and currency effects. Transaction costs are influenced by the business infrastructure, the prevalence of red tape and risks, and marketing costs for advertising and retailing. With increasing distance transport costs rise on average. National borders lead to additional transaction costs and policy barriers for traders. Other factors being equal, both distance and borders result in less trade. Consequently, price transmission caused by physical trade is expected to become weaker over longer distances or across national borders.

\section{Method}

We would like to test whether distance and borders affect the strength and speed of spatial PT. One empirical strategy would be to estimate PT for a large sample of market pairs worldwide and regress coefficients that measure the strength and speed of this PT on variables that measure distance and the presence of a border. Greb et al. (2012) do this for 497 international and domestic price series. Ihle et al. (2011) follow the same approach for 77 maize markets in Eastern Africa. We employ a similar approach with the important difference that rather than estimating price transmission, we draw on the vast number of empirical cereal PT estimates in the literature and conduct a metaanalysis. This tool is popular in natural sciences and medicine to combine empirical evidence from different studies with small sample sizes, and it is becoming increasingly popular in (agricultural) economics (Hess \& von Cramon-Taubadel, 2008). One advantage of meta-analysis in our setting is that it provides us with a much larger sample of observations, markets and countries than we could generate ourselves in a reasonable amount of time.

A second advantage of meta-analysis is closely linked to two challenges. In the literature, each modeler/author has presumably taken a very careful look at his/her data and model specification. This should result in more precise estimates and fewer misspecification errors (e.g. due to disregarded structural breaks and non-linearities) than would obtain if we applied a one-size-fits-all model to a large dataset (see Greb et al., 2012). However, this also poses a challenge because different studies are based on different methodological approaches that are not directly comparable. The empirical price transmission literature is partly driven by model improvements and modifications of existing approaches. To address the issue of methodological heterogeneity, we control for studyand model-specific effects. The second challenge is that the literature sample may be subject to publication bias. For example, papers that present unambiguous and statistically significant results may be favored by peer-review journals (Stanley, 2001, 2005). Alternatively, the literature may reflect what is referred to as the file-drawer effect. In the spatial PT setting, authors might only pursue market pairs that display evidence of PT, and disregard others, so that journals receive for review a disproportionate number of manuscripts that report evidence of PT.

A simple model based on the theoretical considerations above defines PT between two markets as a function of distance and borders, controlling for product-, model- and study specific effects:

$$
\text { Price transmission estimates }=f(\text { distance, } \text { border }, \text { crop, } \text {, model, data })
$$


Two dependent variables proved viable in the coding process. The first is a binary variable that indicates whether the prices being analyzed are cointegrated, i.e. share an equilibrium in the longrun. Standard bivariate cointegration tests are implemented in every statistical software program, and most empirical studies report the results of these tests. The second dependent variable measures the speed of PT. This variable is taken from the workhorse model in bivariate price transmission analysis, which is the vector error correction model (VECM):

$$
\Delta p_{t}=\alpha \beta p_{t-1}+\sum_{i=1}^{k-1} \Gamma_{i} \Delta p_{t-i}+\varepsilon
$$

where $p_{t}$ is a bivariate vector of prices, $\beta^{\prime}=\left(1, \beta_{1}\right)$ is the cointegrating vector such that $\beta^{\prime} p_{t-1}=$ ect measures the equilibrium error or deviation from long-run equilibrium, $\alpha^{\prime}=\left(\alpha_{A}, \alpha_{B}\right)$ is the vector of adjustment parameters that measure the speed with which such deviations are corrected, and $\Gamma_{i}$ describes autoregressive short-run dynamics. We define the second dependent variable as the aggregate speed of adjustment:

$$
A_{A B}=-\alpha_{A}+\alpha_{B}
$$

According to the standard specification of the VECM the $\alpha_{A}$ must be negative to correct deviations from the long-run equilibrium between the two prices. Therefore, subtracting it from $\alpha_{B}$, which is expected to be positive, yields the aggregate price adjustment in both markets, which is a measure of how much of any disequilibrium is corrected per period and, hence, the speed of PT.

A bit less straightforward is the construction of this variable when nonlinearities are introduced to the estimation. Usually this involves some sort of regime switch which allows the adjustment and / or other parameters to change over time. In exogenous break VECMs (Qiu, 2013; Thompson \& Bohl, $1999)$ this switch is an exogenous time point or event, and in Markov switching VECMs (MSVECM) (Brümmer et al., 2009) this switch follows a stochastic process. In threshold VECMs (TVECM) (Goodwin and Piggott, 2001), the size of the deviation $\beta^{\prime} p_{t-1}=e c t$ triggers the regime switch. All of these models can be summarized as follows:

$$
\Delta p_{t}=\alpha^{I_{t}} e c t_{t-1}+\sum_{i=1}^{k-1} \Gamma_{i}^{\left(I_{t}\right)} \Delta p_{t-i}+\varepsilon_{t}
$$

where $I_{t} \in\{1, \ldots, M\}$ is an indicator variable for regimes 1 to $M$ at time $t, M \geq 2$, and $\alpha^{\left(I_{t}\right)}$ are the regime-dependent adjustment speeds in the individual regimes. ${ }^{15}$ To measure the aggregate speed of

\footnotetext{
${ }^{15}$ The TVECM is a special case of regime-switching ECMs and estimated as:
}

$$
\Delta p_{t}=\left\{\begin{array}{c}
\alpha^{(u)} e c t_{t-1}+\sum_{i=1}^{k-1} \Gamma_{i} \Delta p_{t-i}+\varepsilon_{t} \text { if } e c t_{t-1}<\varphi^{u} \\
\alpha^{(m)} e c t_{t-1}+\sum_{i=1}^{k-1} \Gamma_{i} \Delta p_{t-i}+\varepsilon_{t} \text { if } \varphi^{u} \leq e c t_{t-1} \leq \varphi^{l} \\
\alpha^{(l)} e c t_{t-1}+\sum_{i=1}^{k-1} \Gamma_{i} \Delta p_{t-i}+\varepsilon_{t} \text { if } \varphi^{u}<e c t_{t-1}
\end{array}\right.
$$

with upper and lower thresholds $\varphi^{u}, \varphi^{l}$ and the adjustment parameters in the upper, middle and lower regimes: $\alpha^{u}, \alpha^{m}, \alpha^{l}$. Each adjustment parameter is weighed by the relative size of its regime. For the three regime case this is the following equation: 
price adjustment in a model with multiple regimes, we weight the adjustment parameters from each regime by the number of observations in that regime:

$$
A_{A B}=\frac{\sum_{i=1}^{M}\left(\alpha_{B}^{i}-\alpha_{A}^{i}\right) * o b s^{i}}{o b s}
$$

In a number of studies, only one equation of the VECM is reported (e.g. Conforti, 2004b; Minot, 2011). ${ }^{16}$ This usually because the authors assume that one of the two prices is exogenous (e.g. in the case of PT between a large exporter and a small importer) and thus only estimate the adjustment parameter that corresponds to the other price. for such studies, we follow the assumption that this market does practically all the adjustment and use only this first component $\left(-\alpha_{A}\right)$ for the estimation while $\alpha_{B}$ is set zero.

The two dependent variables are regressed on a number of covariates including the variables of interest, distance and border (see Table 1). Distance is measured as the straight airline distance, and the border variable is a dummy that takes one if the two markets $A$ and $B$ are separated by an international border. We include a crop dummy in all estimated equations to capture any systematic differences between cereals (Table 1). A dummy variable indicates estimates from peer reviewed studies in order to explore a publication bias effect. Altogether, the basic meta-regression that we estimate is:

$$
\begin{gathered}
Y=\beta_{0}+\beta_{1} \text { dist }+\beta_{2} \text { border }+\beta_{3} \text { dist } * \text { border }+\beta_{4} \text { crop }+\beta_{5} \text { peer. reviewed } \\
+\beta_{5} \text { levels }+\varepsilon
\end{gathered}
$$

where $Y$ is either a dummy which measures whether the two prices are cointegrated (LOGIT), or the aggregate speed of PT defined above (OLS). An interaction term for the distance and border variables is included in order to differentiate the effect of inland distance from that of international distance. This accounts for other dominating modes of transport in international trade (ship, airplane) than in domestic trade (cars, railroad).

When $\mathrm{Y}$ is the aggregate speed of PT, we test the influence of several additional explanatory dummy variables. First, it has been demonstrated that the frequency of the underlying data affects the size of the adjustment parameters in a VECM (Amikuzuno, 2010; von Cramon-Taubadel et al., 2003). We include dummy variables for different data frequencies to account for this factor. Second, a dummy captures the effect of the different statistical properties of the underlying price series in levels or in logarithmic form (levels). Third, a variable takes into account whether the cointegrating vector is restricted to $[1,-1]$ or estimated (beta.restrict). Fourth, if in the estimation one of the two markets is assumed exogenous the variable B.exogenous equals one and zero otherwise. Fifth, the authors can include the possibility of price transmission changing over time into the modelling process in different ways. We expect the respective specifications to affect the results. One is a structural break in the long-run equilibrium (beta.break). Other specifications allow for a change in the speed of price adjustment in ECMs (break.ecm) or SEECMs (break.seecm). Breaks may also occur following markovswitching regime changes (msvecm). Threshold models with two or three regimes let the speed of adjustment speed vary depending on the size of the price change relative to estimated threshold values. We employ two dummies, tvecm. 2 and tvecm.3, to account for the expected heterogeneity in the estimates.

$$
A_{A B}=\frac{\left(\alpha_{B}^{u}-\alpha_{A}^{u}\right) * o b s^{u}+\left(\alpha_{B}^{m}-\alpha_{A}^{m}\right) * o b s^{m}+\left(\alpha_{B}^{l}-\alpha_{A}^{l}\right) * o b s^{l}}{o b s}
$$

In a two regime TVECM, the two thresholds can also be symmetric with $\varphi^{u}=\varphi^{l}$, yielding one inner and one outer regime. The weighing is adapted accordingly.

${ }^{16}$ Phillips and Loretan (1991) introduced the term single equation error correction model (SEECM) for this model type. 
The addition of these explanatory variables results in the following model:

$$
\begin{aligned}
A_{A B}=\beta_{0}+ & \beta_{1} \text { dist }+\beta_{2} \text { border }+\beta_{3} \text { dist } * \text { border }+\beta_{4} \text { crop }+\beta_{5} \text { peer. reviewed } \\
& +\beta_{6} \text { levels }+\beta_{7} \text { frequency }+\beta_{8} \text { msvecm }+\beta_{9} \text { tvecm. } 2+\beta_{10} \text { tvecm. } 3 \\
& +\beta_{11} \text { beta.break }+\beta_{12} \text { break.ecm }+\beta_{13} \text { break. seecm } \\
& +\beta_{14} \text { beta.restrict }+\beta_{14} \text { B.exogenous }+\varepsilon
\end{aligned}
$$

These models are estimated in un-weighted form, and using a weighing scheme, in which each observation is weighted by the inverse number of observations taken from the same study. This gives each study in our meta-sample the same weight (WLS). This is potentially important because in particular two studies in our meta-sample (Hernandez-Villafuerte, 2011 with 273 observations, and Greb et al. 2012 with 497 observations - see Annex Table 2) account for a disproportionate share of the total of 1189 observations at our disposal.

\section{Data and estimation}

Price transmission literature is a wide field and it is a demanding task to extract those studies that are suitable for the intended meta regression. A first, explorative search was conducted on AgEconSearch $^{17}$, where the keywords cointegration and price transmission produced 689 hits. Based on a systematic screening of all titles and abstracts we developed a search algorithm to find those studies that report PT estimates for spatially separated markets (see Annex). This was used for an exhaustive search in March 2013 on ISI Web of Knowledge which resulted in 962 studies. A weekly search alert added 38 studies to the sample. In addition, we used online searches of 62 journals of Agricultural Economics with the keywords price transmission, cointegration, ECM and error correction (see Annex). 11604 titles were screened and 163 studies were added to the sample. A similar search of the first 1000 hits on Google scholar (scholar.google.de) added another 27 studies. A list of references and several other sources added a further 49 studies. To assess the consistency of the study selection by the reviewers we performed Cohen's Kappa test (Cohen, 1960). Two independent reviewers screened 655 study titles retrieved on ISI Web of Science and the overlap of their study selection was compared with the test. The result indicates moderate agreement $(0.570)$ which is sufficient for a systematic review.

After checking for duplicates and updated versions, we were left with 1648 non-duplicate studies. We screened the information in abstracts and retrieved from this sample all English-language studies of spatial grain price transmission. We further limited the sample to include only those that employ some sort of ECM, data from after 1980, and data of at least quarterly frequency. Conference posters were excluded in general. This selection procedure left us with 189 studies that were subjected to detailed screening. Of these, 57 studies proved suitable for coding with all required parameters reported.

\footnotetext{
${ }^{17}$ http://ageconsearch.umn.edu
} 
Table 1: Variables and description with descriptive statistics

\begin{tabular}{|c|c|c|c|c|c|c|}
\hline & Variable & Description & sum & mean & $\min$ & $\max$ \\
\hline \multirow{2}{*}{$>$} & cointegration & tested at $5 \%$ level of significance & 708 & 0.595 & 0 & 1 \\
\hline & $A_{A B}$ & $\alpha_{B}-\alpha_{A}$ & - & 0.255 & -0.434 & 1.486 \\
\hline \multirow{2}{*}{$x$} & distance & airline distance in $1000 \mathrm{~km}$ & - & 5.785 & 0.019 & 19.713 \\
\hline & border & $=1$ if border separates price pairs & 761 & 0.640 & 0 & 1 \\
\hline \multirow{7}{*}{$\frac{0}{0}$} & rice & $=1$ for rice ( 0 otherwise) & 641 & 0.539 & 0 & 1 \\
\hline & maize & $=1$ for maize & 385 & 0.324 & 0 & 1 \\
\hline & wheat & $=1$ for wheat & 133 & 0.112 & 0 & 1 \\
\hline & soybeans & $=1$ for soybeans & 20 & 0.017 & 0 & 1 \\
\hline & sorghum & = 1 for sorghum & 6 & 0.005 & 0 & 1 \\
\hline & teff & $=1$ for teff & 1 & 0.001 & 0 & 1 \\
\hline & barley & $=1$ for barley & 3 & 0.002 & 0 & 1 \\
\hline 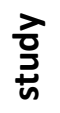 & peer.reviewed & $\begin{array}{l}=1 \text { if article underwent peer review } \\
\text { before published }\end{array}$ & 111 & 0.093 & 0 & 1 \\
\hline$\frac{\pi}{\pi}$ & levels & $\begin{array}{l}=1 \text { if series are in levels rather than } \\
\text { logarithms }\end{array}$ & 37 & 0.031 & 0 & 1 \\
\hline \multirow{9}{*}{$\begin{array}{l}\bar{d} \\
\frac{0}{0} \\
\text { 인 }\end{array}$} & ecm & $=1$ if error correction model & 833 & 0.701 & 0 & 1 \\
\hline & B.exogenous & $=1$ if one market is exogenous & 210 & 0.176 & 0 & 1 \\
\hline & beta.break & $=1$ for VECM with break in beta & 121 & 0.102 & 0 & 1 \\
\hline & break.ecm & $=1$ for VECM with break & 5 & 0.004 & 0 & 1 \\
\hline & break.seecm & $\begin{array}{l}=1 \text { for break in model with one } \\
\text { exogenous market }\end{array}$ & 6 & 0.005 & 0 & 1 \\
\hline & markov & $=1$ for MSVECM & 9 & 0.008 & 0 & 1 \\
\hline & tvecm.2 & $=1$ for 2 regime TVECM & 14 & 0.012 & 0 & 1 \\
\hline & tvecm.3 & $=1$ for 3 regime TVECM & 18 & 0.015 & 0 & 1 \\
\hline & beta.restrict & $=1$ if cointegrating vector is set unity & 35 & 0.029 & 0 & 1 \\
\hline \multirow{5}{*}{$\begin{array}{l}\text { ป̀ } \\
\frac{c}{0} \\
\frac{0}{0} \\
\frac{0}{4}\end{array}$} & monthly & $=1$ for monthly data & 1096 & 0.922 & 0 & 1 \\
\hline & daily & = 1 for daily data & 28 & 0.024 & 0 & 1 \\
\hline & every4days & $=1$ for 4 -daily data & 4 & 0.003 & 0 & 1 \\
\hline & weekly & = 1 for weekly data & 58 & 0.049 & 0 & 1 \\
\hline & quarterly & = 1 for quarterly data & 3 & 0.003 & 0 & 1 \\
\hline 齐 & $\begin{array}{l}\text { study size } \\
\text { (weights) }\end{array}$ & *av. number of observations per study & - & *20.86 & 1 & 497 \\
\hline
\end{tabular}

Note: $N=1189$, each observation is one extracted price pair from a sample of 57 studies.

The extracted market pairs sum up to 1189 observations of which 167 come from nonlinear model specifications. Overall, $59.5 \%$ of all market pairs are cointegrated. If a price shock occurs, prices in both markets correct this deviation on average by $26 \%$ in each following period. The median is 0.213 with a right-skewed distribution (Figure 1). 


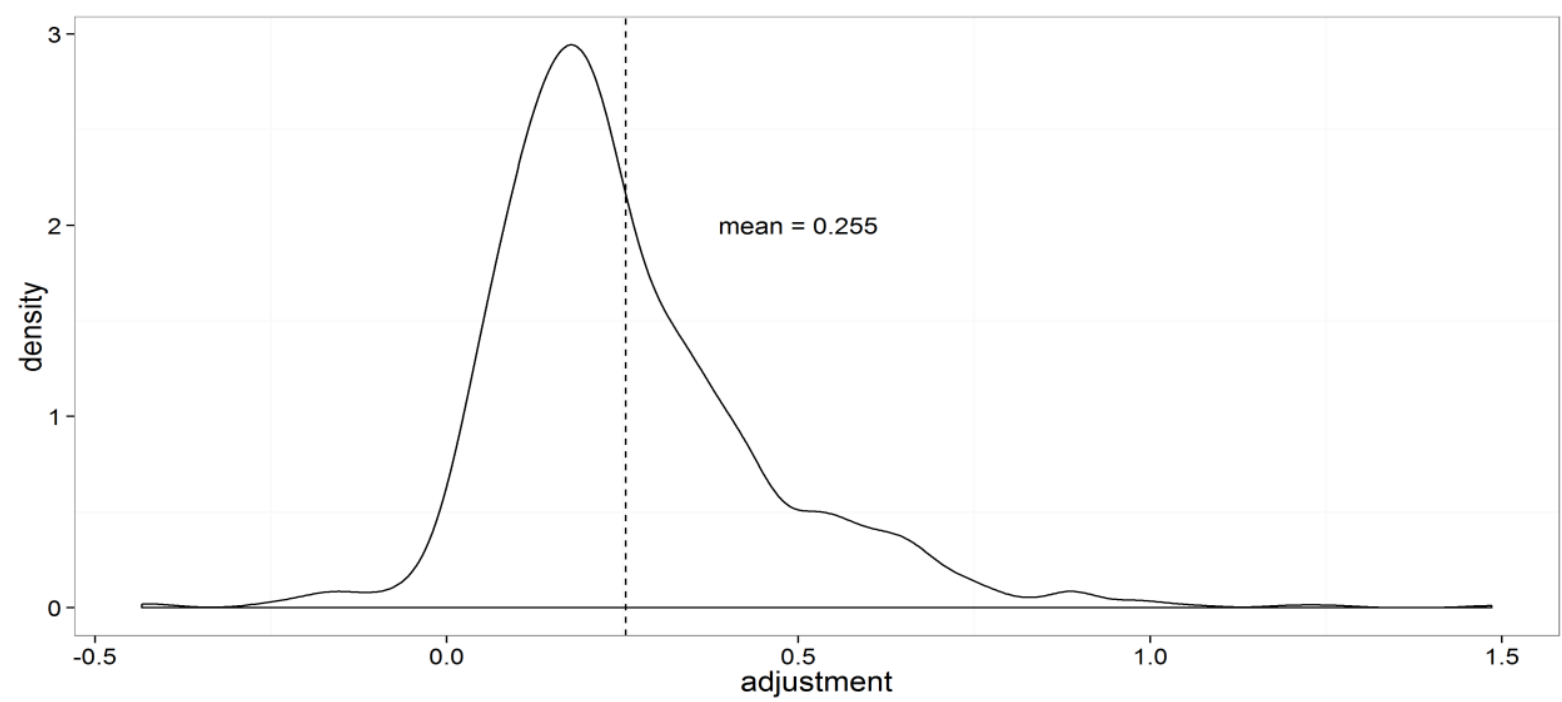

The mean of geographical distance is 5785 kilometers and $64 \%$ of the market pair are divided by a border. These two main explanatory variables are correlated, as illustrated in the density plot in Figure 2. If two markets are located in the same country, the distance between them never exceeds 5000 kilometers. Markets divided by a border are separated by as much as 19713 kilometers (LimaBangkok)

Figure 2: Density plot of distance and borders

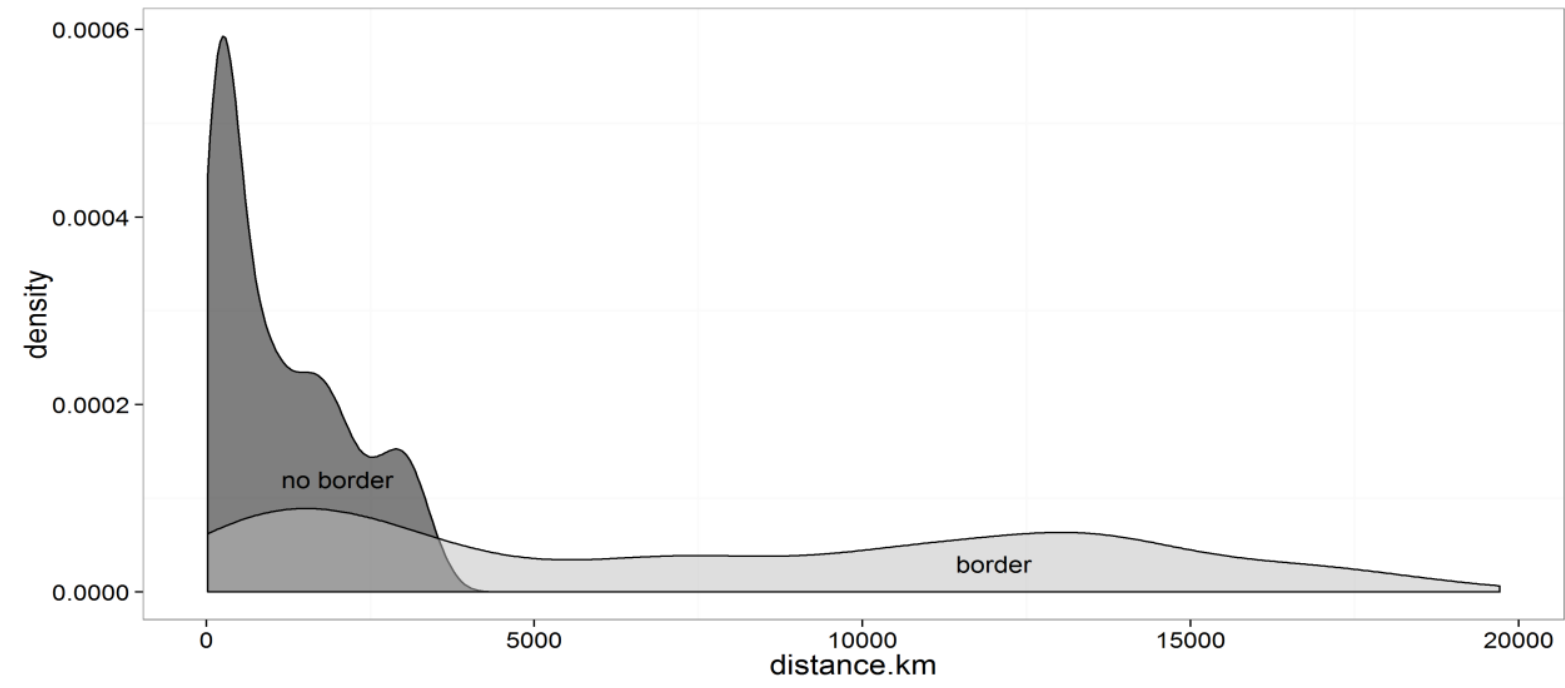

More than half of the observations are taken from the studies of rice PT (53.9\%), followed by maize with $32.4 \%$ and wheat with $11.2 \%$. Soybeans, sorghum, teff and barley account for the remaining 2.5\% of the sample. $70.1 \%$ of the 1189 PT estimates in the meta-dataset are produced using linear VECMs. $10.2 \%$ of the estimates are modeled with a structural break in the long run equilibrium and $0.9 \%$ with a structural break in the price adjustment coefficients. In $17.6 \%$ of the cases the authors assume that the second price exogenous and only estimate one equation. Only $3.5 \%$ of the observations are estimated with more complex nonlinear models such as the MSVECM or the TVECM. Most price series are of monthly frequency (92.2\%), and almost studies employ prices in logarithms (96.9\%). While 24 of the 57 studies are published in peer reviewed journals, these contribute only $9.3 \%$ of the observations in the sample. On average, each study provides 21 observations. 


\section{Results and discussion}

Meta-regression results in Table 2 indicate that distance and borders have statistically significant and negative effects on both the likelihood of cointegration and the speed of price adjustment. The size of these effects differs according to model specification and weighting scheme.

Table 2: Results from meta-regressions

\begin{tabular}{|c|c|c|c|c|c|c|c|}
\hline \multicolumn{2}{|c|}{ Dependent variable $\rightarrow$} & \multicolumn{2}{|c|}{ cointegration } & \multicolumn{4}{|c|}{ speed of adjustment } \\
\hline Type $\downarrow$ & Covariate $\downarrow$ & LOGIT & (se) & OLS & (se) & WLS & (se) \\
\hline & (Intercept) & $0.346^{*}$ & (0.096) & $0.368^{*}$ & (0.023) & $0.468^{*}$ & $(0.036)$ \\
\hline \multirow[t]{3}{*}{$x$} & distance & -0.069 & $(0.040)$ & -0.057 & $(0.012)$ & -0.199 & (0.033) \\
\hline & border & $-0.225^{* *}$ & (0.104) & -0.020 & (0.028) & $-0.127^{* * *}$ & (0.029) \\
\hline & distance *border & 0.059 & $(0.040)$ & $0.056^{* * *}$ & $(0.012)$ & $0.186^{* * *}$ & $(0.033)$ \\
\hline \multirow[t]{6}{*}{ crop } & maize & $-0.154^{*}$ & (0.049) & -0.012 & $(0.021)$ & -0.001 & (0.025) \\
\hline & wheat & $-0.109^{*}$ & $(0.056)$ & $-0.102^{* *}$ & $(0.030)$ & $-0.035^{*}$ & $(0.020)$ \\
\hline & soybeans & 0.289 & $(0.250)$ & -0.086 & (0.055) & -0.057 & $(0.040)$ \\
\hline & sorghum & -0.170 & (0.207) & 0.052 & (0.135) & 0.178 & $(0.126)$ \\
\hline & teff & 0.453 & $(0.382)$ & 0.030 & (0.192) & -0.049 & (0.062) \\
\hline & barley & $0.461^{* *}$ & $(0.222)$ & -0.002 & $(0.115)$ & -0.001 & $(0.060)$ \\
\hline study & peer.reviewed & -0.117 & (0.091) & $0.078^{*}$ & (0.038) & 0.050 & $(0.020)$ \\
\hline data & levels & 0.292 & (0.181) & 0.102 & (0.045) & -0.040 & (0.026) \\
\hline \multirow[t]{4}{*}{ frequency } & daily & & & -0.229 & $(0.060)$ & -0.251 & $(0.045)$ \\
\hline & every 4 days & & & $-0.295^{* *}$ & (0.130) & $-0.355^{*}$ & (0.073) \\
\hline & weekly & & & 0.001 & $(0.037)$ & $-0.092^{*}$ & $(0.024)$ \\
\hline & quarterly & & & -0.133 & (0.156) & $-0.266^{* * *}$ & $(0.066)$ \\
\hline \multirow[t]{15}{*}{ model } & msvecm & & & 0.092 & (0.083) & $0.200^{* *}$ & $(0.056)$ \\
\hline & tvecm.2 & & & -0.040 & (0.064) & $-0.073^{*}$ & (0.039) \\
\hline & tvecm.3 & & & -0.056 & $(0.081)$ & $-0.185^{* * *}$ & (0.043) \\
\hline & beta.break & & & $0.050^{* *}$ & (0.024) & $0.211^{* *}$ & $(0.090)$ \\
\hline & break.ecm & & & -0.124 & (0.099) & $-0.177^{*}$ & (0.050) \\
\hline & break.seecm & & & -0.171 & (0.114) & $-0.168^{* * *}$ & $(0.056)$ \\
\hline & beta.restrict & & & 0.012 & (0.067) & $0.117^{* * *}$ & (0.030) \\
\hline & B.exogenous & & & $-0.130^{* * *}$ & $(0.023)$ & $-0.110^{*}$ & (0.018) \\
\hline & AIC & \multicolumn{6}{|l|}{1301.977} \\
\hline & $\mathrm{BIC}$ & \multicolumn{6}{|l|}{1360.774} \\
\hline & Log Likelihood & \multicolumn{6}{|l|}{-638.989} \\
\hline & Deviance & \multicolumn{6}{|l|}{1277.977} \\
\hline & Num. obs. (df) & \multicolumn{2}{|c|}{$992(d f=980)$} & \multicolumn{2}{|l|}{$705(d f=681)$} & \multicolumn{2}{|c|}{$705(d f=681)$} \\
\hline & (Pseudo-) $\mathrm{R}^{2}$ & \multirow{2}{*}{\multicolumn{2}{|c|}{0.120}} & \multicolumn{2}{|l|}{0.152} & \multicolumn{2}{|l|}{0.275} \\
\hline & $\operatorname{Adj} . R^{2}$ & & & \multicolumn{2}{|l|}{0.123} & \multicolumn{2}{|l|}{0.251} \\
\hline
\end{tabular}

Note: In the logistic model specification, average marginal effects rather than coefficient estimates and a Pseudo-R2 are reported. WLS model observations are weighted by inverse study size. Reported are standard errors in brackets and significance levels: ${ }^{* *} p<0.01, * * p<0.05,{ }^{*} p<0.1$.

According to the LOGIT specification, the probability of cointegration between two prices falls by $22.5 \%$ if the markets in question are separated by an international border. The probability of 
cointegration between two prices within a country falls by $6.9 \%$ with each additional 1000 kilometer airline distance. The interaction term is not statistically significant at the $10 \%$ level, indicating that the distance effect is the same for two markets separated by an international border. Compared to the base category rice, maize and wheat prices are on average $15.4 \%$ and $10.9 \%$ less often cointegrated, while barley price pairs are $46.1 \%$ more likely cointegrated. Cointegration test results in peer-reviewed articles do not differ statistically significant from grey literature studies. Compared with rice, wheat market pairs are $10.2 \%$ less often cointegrated. Moreover, whether the price series were log-transformed or estimated in levels does not affect the cointegration test results.

A negative and significant effect of distance on the speed of price transmission is common to all linear model specifications. Each 1000 kilometers of inland distance reduce the speed of adjustment by 5.7 percent, international distance however only by $0.01 \%$. A border reduces the speed on average by $2 \%$, however the effect is not statistically significant. In peer-reviewed publications the speed of adjustment is $7.8 \%$ faster than in grey literature studies, pointing slightly to publication bias towards larger coefficients. Price series in levels produce $10.2 \%$ faster price transmission results than log-transformed series. This effect originates from the different statistical properties of series in levels and logs, e.g. with the logarithmic form exhibiting less variation. Using higher daily or 4-daily price data for the estimation, price adjustment is $23 \%$ and $30 \%$ faster respectively compared to monthly data frequency. This confirms findings of the impact of data aggregation on price transmission parameters (von Cramon-Taubadel et al., 2003). Only two model-type variables affect the results, namely a break in the long-run equilibrium increases the adjustment speed by $5 \%$ and in estimations with one exogenous market, the price adjustment is $13 \%$ slower.

In the WLS estimation the results indicate a much higher distance effect with $19.9 \%$ slower price adjustment per 1000 kilometers and $12.7 \%$ slower adjustment in presence of a border. The interaction term also decreases an international distance effect to only $1.3 \%$. Transmission of wheat prices is on average $3.5 \%$ slower than transmission of rice prices, while adjustment speeds of other crops do not differ significantly from rice. Estimated speeds of adjustment in peer reviewed journals are $5 \%$ higher than in grey literature studies. This may be evidence of publication bias in journals in favor of studies with stronger results. Another possible explanation is that studies undergo a peer review that sorts out lower quality results and results in more accurate estimates of price transmission parameters. Model type variables explain the variance in results far better in the WLS than the unweighted specification. Adjustment speeds in MSVECMs are $20 \%$ higher and $7.3 \%$ and 18.5\% slower for TVECMs with 2 and 3 regimes, respectively. A break that allows for different long run equilibria increases price transmission by $21.1 \%$. Models with structural breaks in the adjustment process decrease the speed of adjustment by $17.7 \%$ for ECMs and $16.8 \%$ for ECMs with one endogenous market. Price transmission is $11.7 \%$ faster when the price transmission coefficient is restricted to 1 in the price transmission equation. If one market is exogenous, the adjustment speed is $11 \%$ slower. The coefficient of determination of the meta-regressions indicates that the covariates explain between $12 \%$ and $28 \%$ of the variation in the results.

\section{Conclusion}

We test whether the distance between two markets and whether they are separated by an international borders affects the strength and speed of price transmission between them. To do so we extract measures of the strength and speed of spatial cereal price transmission from the empirical PT literature, and regress these on the distance between markets and whether there is a border between them. The results of a number of meta-regression specifications confirm that distance and borders have significant effects on cointegration and the speed of price transmission. We find that distance effects are only economically significant for the speed of price transmission within a country. If two markets are separated by an international border, the distance effect is negligible. This confirms findings on international trade that transportation costs over longer 
distances are disproportionally low compared to those over shorter distances. Freight rates may thus not inhibit market integration over longer distances so that price transmission is almost unaffected by international distance. Furthermore, the properties of the data and the model choice also influence price transmission findings. When interpreting estimates from price transmission studies, these effects have to be taken into account. The policy implications of this study point at the relevance of borders and distance when focusing on market integration. Policy measures targeted at specific markets may not affect distant or foreign partner markets.

We have tested whether linear distance has an effect on the strength and speed of price transmission. The effect of distance might be nonlinear however, as different modes of transportation are used to cover different distances in cereal trade. Future research could look for evidence of such nonlinear effects, for example using semi-parametric techniques. 


\section{References}

Abdulai A (2006) Spatial integration and price transmission in agricultural commodity markets in subSaharan Africa. In: Agricultural Commodity Markets and Trade - New Approaches to Analyzing Market Structure and Instability, Sarris, A. \& Hallam, D., pp. 163-186.

Aker J, Klein M, Connell S, et al. (2013) Borders, Ethnicity and Trade. Tufts University Working Paper Series, 1-72.

Amikuzuno J (2010) Spatial Price Transmission Analysis in Agricultural Markets: Does the Data Frequency Improve our Estimation? Meeting of the African Association of Agricultural Economists (AAEA), Cape Town, South Africa, 1-19.

Amikuzuno J and Donkoh SA (2012) Border effects on spatial price transmission between fresh tomato markets in Ghana and Burkina-Faso: Any case for promoting trans-border trade in West Africa? Journal of International Agricultural Trade and Development, 8(1), 81-98.

Amikuzuno J and Ogundari K (2013) Price transmission analysis and associated policy in Sub-Saharan Africa's agricultural markets: What does the literature say? Annual Meeting of the African Association of Agricultural Economists, Hammamet, Tunisia, 1-32.

Anderson J and Van Wincoop E (2004) Trade costs. Journal of Economic Literature, 42(3), 691-751.

Bakucs Z, Fałkowski J and Fertő I (2013) Does Market Structure Influence Price Transmission in the Agro-food Sector? A Meta-analysis Perspective. Journal of Agricultural Economics, 1-25.

Brümmer B, von Cramon-Taubadel S and Zorya S (2009) The impact of market and policy instability on price transmission between wheat and flour in Ukraine. European Review of Agricultural Economics, 36(2), 203-230.

Cohen J (1960) A Coefficient of Agreement for Nominal Scales. Educational and Psychological Measurement, 20(1), 37-46.

Conforti P (2004) Price transmission in selected agricultural markets. FAO Commodity and Trade Policy Research Working Paper Series, (7), 1-91.

Cudjoe G, Breisinger C and Diao X (2010) Local impacts of a global crisis: Food price transmission, consumer welfare and poverty in Ghana. Food Policy, Elsevier Ltd, 35(4), 294-302.

Engel C and Rogers J (1995) How wide is the border? International Finance Discussion Papers, 498, 140.

FAO, IFAD and WFP (2011) The State of Food Insecurity in the World - How does international price volatility affect domestic economies and food security? Food and Agricultural Organization, Rome, Italy, Rome.

Goletti F, Ahmed R and Farid N (1995) Structural determinants of market integration: the case of rice markets in Bangladesh. The Developing Economies, 23(2), 185-202. 
Goodwin BK and Piggott NE (2001) Spatial Market Integration in the Presence of Threshold Effects. American Journal of Agricultural Economics, 83(2), 302-317.

Greb F, Jamora N, Mengel C, et al. (2012) Price transmission from international to domestic markets. GlobalFood Discussion Papers, GlobalFood Discussion Papers, Göttingen, Germany, 15, 1-48.

Hernandez-Villafuerte K (2011) The relationship between spatial integration and geographical distance in Brazil. Annual Meeting of the European Association of Agricultural Economics (EAAE), Zürich, Switzerland, Zürich, 1-37.

Hess S and von Cramon-Taubadel S (2008) A Meta-Analysis of General and Partial Equilibrium Simulations of Trade Liberalisation under the Doha Development Agenda. The World Economy, 31(6), 804-840.

Ihle R, Cramon-Taubadel S von, Zorya S, et al. (2011) Measuring the integration of staple food markets in Sub-Saharan Africa: Heterogeneous infrastructure and cross border trade in the East African community. CESifo Working Paper Series, 3413, 1-33.

McCallum J (1995) National borders matter: Canada-US regional trade patterns. The American Economic Review, 85(3), 615-623.

Minot N (2011) Transmission of World Food Price Changes to Markets in Sub-Saharan Africa. IFPRI Discussion Paper Series, 01059, 1-44.

Phillips P and Loretan M (1991) Estimating long-run economic equilibria. The Review of Economic Studies, (58), 407-436.

Qiu F (2013) Dynamic impacts of export controls on price transmission. Annual Meeting of the Agricultural and Applied Economics Association (AAEA), Washington, United States, 1-13.

Rapsomanikis G, Hallam D and Conforti P (2006) Market integration and price transmission in selected food and cash crop markets of developing countries: review and applications. In: Agricultural Commodity Markets and Trade (Alexander S. and Hallam, D.), pp. 187-217.

Rashid S (2011) Intercommodity price transmission and food price policies: An analysis of Ethiopian cereal markets. IFPRI Discussion Paper Series, 01079, 1-28.

Stanley T (2001) Wheat From Chaff: Meta-Analysis As Quantitative Literature Review. Journal of Economic Perspectives, 15(3), 131-150.

Stanley T (2005) Beyond publication bias. Journal of Economic Surveys, 19(3), 309-345.

Thompson S and Bohl M (1999) International wheat price transmission and CAP reform. In: Annual Meeting of the American Agricultural Economics Association (AAEA), pp. 1-20.

Von Cramon-Taubadel S, Loy J-P and Meyer J (2003) The impact of data aggregation on the measurement of vertical price transmission: evidence from German food prices. Annual Meeting of the American Agricultural Economics Association (AAEA), Montreal, Canada, 1-17. 


\section{Appendix}

Table 1: List of peer-reviewed journals with number of keyword hits

\begin{tabular}{|c|c|c|c|c|c|c|}
\hline \multirow[b]{2}{*}{$\begin{array}{l}\text { Study } \\
\text { no. }\end{array}$} & \multirow[b]{2}{*}{ Name of journal (J) } & \multirow[b]{2}{*}{ access via } & \multicolumn{4}{|c|}{ number of hits } \\
\hline & & & $\begin{array}{l}\text { price } \\
\text { transmission }\end{array}$ & cointegration & ecm & $\begin{array}{l}\text { error } \\
\text { correction }\end{array}$ \\
\hline 1 & Acta Oeconomica et Informatica & fem.uniag.sk & 63 & 6 & 29 & 47 \\
\hline 2 & African J of Agricultural Research & academicjournal.org & 606 & 269 & 309 & 898 \\
\hline 3 & Agribusiness: An International J & Wiley & 112 & 49 & 9 & 89 \\
\hline 4 & Agricultural and Food Science & ojs.tsv.fi & 2 & 1 & 0 & 2 \\
\hline \multirow{2}{*}{5} & \multirow{2}{*}{ Agricultural Economics } & Science Direct & 62 & 33 & 14 & 88 \\
\hline & & Wiley & 111 & 71 & 20 & 144 \\
\hline 6 & Agricultural Economics Research Review & EBSCO & 2 & 2 & 0 & 0 \\
\hline 7 & Agricultural Finance Review & Emerald & 0 & 1 & 0 & 1 \\
\hline 8 & Agricultural Systems & Science Direct & 62 & 4 & 7 & 123 \\
\hline 9 & Agriculture and Human Values & Springer & 37 & 0 & 1 & 15 \\
\hline 10 & Agriculture, Ecosystems and Environment & Science Direct & 35 & 0 & 12 & 267 \\
\hline 11 & Agroforestry Systems & Springer & 24 & 0 & 84 & 216 \\
\hline 12 & American J of Agricultural Economics & EBSCO & 19 & 22 & 1 & 14 \\
\hline \multirow{2}{*}{13} & \multirow{2}{*}{ Applied Economics Letters } & EBSCO & 7 & 286 & 16 & 114 \\
\hline & & Taylor \& Francis & 118 & 700 & 167 & 549 \\
\hline 14 & Asian Agricultural Research & scialert.net & 0 & 0 & 0 & 0 \\
\hline \multirow{2}{*}{15} & \multirow{2}{*}{ Australian J of Agricultural and Resource Economics } & Wiley & 52 & 22 & 4 & 69 \\
\hline & & EBSCO & 2 & 6 & 0 & 2 \\
\hline 16 & Bio-based and Applied Economics & fupress.net & 5 & 0 & 0 & 2 \\
\hline
\end{tabular}




\begin{tabular}{|c|c|c|c|c|c|c|}
\hline \multirow{2}{*}{$\begin{array}{l}\text { Study } \\
\text { no. }\end{array}$} & \multirow[b]{2}{*}{ Name of journal (J) } & \multirow[b]{2}{*}{ access via } & \multicolumn{4}{|c|}{ number of hits } \\
\hline & & & $\begin{array}{l}\text { price } \\
\text { transmission }\end{array}$ & cointegration & ecm & $\begin{array}{l}\text { error } \\
\text { correction }\end{array}$ \\
\hline 17 & British Food J & Emerald & 31 & 2 & 0 & 9 \\
\hline 18 & Canadian J of Agricultural Economics & Wiley & 98 & 59 & 15 & 106 \\
\hline 19 & Computers and Electronics in Agriculture & Science Direct & 65 & 0 & 6 & 329 \\
\hline 20 & Economia & anpec.org.br/revista & 110 & 165 & 19 & 145 \\
\hline 21 & European Review of Agricultural Economics & Oxford Journals & 1483 & 39 & 10 & 588 \\
\hline 22 & Food Policy & Science Direct & 101 & 17 & 5 & 60 \\
\hline 23 & Food Quality and Preference & Science Direct & 13 & 0 & 0 & 96 \\
\hline 24 & J of Agricultural and Food Industrial Organization & De Gruyter & 16 & 7 & 2 & 11 \\
\hline 25 & J of Agricultural Economics & Wiley & 109 & 51 & 16 & 141 \\
\hline 26 & $\begin{array}{l}\text { J of Agriculture and Rural Development in the Tropics and } \\
\text { Subtropics }\end{array}$ & jarts.info & 1 & 1 & 0 & 0 \\
\hline \multirow{2}{*}{27} & \multirow{2}{*}{ J of Applied Economics } & EBSCO & 0 & 12 & 3 & 7 \\
\hline & & IDEAS & 0 & 26 & 3 & 9 \\
\hline \multirow{2}{*}{28} & \multirow{2}{*}{ J of Development Studies } & EBSCO & 1 & 0 & 2 & 5 \\
\hline & & Taylor \& Francis & 107 & 42 & 29 & 152 \\
\hline \multirow{2}{*}{29} & \multirow{2}{*}{ J of International Agricultural Trade \& Development } & EBSCO & 1 & 16 & 1 & 6 \\
\hline & & Taylor \& Francis & 44 & 57 & 15 & 46 \\
\hline 30 & J of Policy Reform & EBSCO & 1 & 0 & 0 & 0 \\
\hline 31 & J of Regional Analysis and Policy & jrap-J.org & 6 & 8 & 2 & 33 \\
\hline 32 & J of Rural Development & krei.re.kr & 10 & 10 & 10 & 10 \\
\hline 33 & $\begin{array}{l}\text { J of Sustainable Agriculture / Agroecology and Sustainable Food } \\
\text { Systems }\end{array}$ & Taylor \& Francis & 11 & 0 & 1 & 1 \\
\hline 34 & Marine Resource Economics & BioOne & 3 & 2 & 0 & 13 \\
\hline
\end{tabular}




\begin{tabular}{|c|c|c|c|c|c|c|}
\hline \multirow{2}{*}{$\begin{array}{l}\text { Study } \\
\text { no. }\end{array}$} & \multirow[b]{2}{*}{ Name of journal (J) } & \multirow[b]{2}{*}{ access via } & \multicolumn{4}{|c|}{ number of hits } \\
\hline & & & $\begin{array}{l}\text { price } \\
\text { transmission }\end{array}$ & cointegration & ecm & $\begin{array}{l}\text { error } \\
\text { correction }\end{array}$ \\
\hline 35 & Renewable Agriculture and Food Systems & Cambridge Js & 8 & 0 & 3 & 24 \\
\hline 36 & Review of Agricultural Economics & EBSCO & 0 & 2 & 1 & 2 \\
\hline 37 & Stata J & stata-J.com & 0 & 3 & 0 & 1 \\
\hline 38 & Studies in Agricultural Economics & aki.gov.hu & 0 & 0 & 0 & 0 \\
\hline 39 & Western J of Agricultural Economics & jstor.org & 0 & 0 & 0 & 0 \\
\hline 40 & World Development & Science Direct & 368 & 82 & 19 & 356 \\
\hline \multicolumn{3}{|c|}{ Sum of hits } & 3906 & 2073 & 835 & 4790 \\
\hline & \multicolumn{6}{|l|}{ Journals included in AgEcon Search: } \\
\hline 41 & \multicolumn{6}{|l|}{ J of Agricultural and Applied Economics } \\
\hline 42 & \multicolumn{6}{|l|}{ Agrekon } \\
\hline 43 & \multicolumn{6}{|l|}{ Agricultural and Resource Economics Review } \\
\hline 44 & \multicolumn{6}{|l|}{ Australian J of Agricultural Economics } \\
\hline 45 & \multicolumn{6}{|l|}{ Brazilian J of Rural Economy and Sociology } \\
\hline 46 & \multicolumn{6}{|l|}{ Current Agriculture, Food and Resource Issues } \\
\hline 47 & \multicolumn{6}{|l|}{ International Food and Agribusiness Management Review } \\
\hline 48 & \multicolumn{6}{|l|}{ J of Agribusiness } \\
\hline 49 & \multicolumn{6}{|l|}{ J of Agricultural and Resource Economics / WJAE / WEF } \\
\hline 50 & \multicolumn{6}{|l|}{ Scientific J on Agricultural Economics } \\
\hline
\end{tabular}


Acosta, A., 2012. Measuring spatial transmission of white maize prices between South Africa and Mozambique: An asymmetric error correction model approach. African Journal of Agricultural and Resource Economics, 7(1), pp.1-13.

Alam, M. \& Begum, I., 2012. World and Bangladesh rice market integration: An application of threshold cointegration and threshold vector error correction model (TVECM). In Annual Conference of the Agricultural Economics Society (AES), Warwick, United Kingdom. University of Warwick, UK, pp. 1-19.

Alam, M. et al., 2012. Measuring Market Integration in the Presence of Threshold Effect: The Case of Bangladesh Rice Markets. In Agricultural \& Applied Economics Association`s (AAEA) Conference, Seattle, Washington, USA. Washington, USA, pp. 1-27.

Alam, M.J. et al., 2012. The dynamic relationships between world and domestic prices of rice under the regime of agricultural trade liberalization in Bangladesh. Journal of the Asia Pacific Economy, 17(1), pp.113-126.

Araujo-Enciso, S., 2009. Evidence of non-linear price transmission between maize markets in Mexico and the US. In International Association of Agricultural Economists Conference, Beijing, China. Beijing, China, pp. 1-23.

Baek, J. \& Koo, W.W., 2006. Price Dynamics in the North American Wheat Market. Agricultural and Resource Economics Review, 2(October 2003), pp.265-275.

Balcombe, K., Bailey, A. \& Brooks, J., 2007. Threshold Effects in Price Transmission: The Case of Brazilian Wheat, Maize, and Soya Prices. American Journal of Agricultural Economics, 89(2), pp.308-323.

Baquedano, F.G., Liefert, W. \& Shapouri, S., 2011. World market integration for export and food crops in developing countries: a case study for Mali and Nicaragua. Agricultural Economics, 42(5), pp.619-630.

Baulch, B. \& Hansen, H., 2008. The spatial integration of paddy markets in Vietnam. Journal of Agricultural Economics, 59(2), pp.271-295.

Brosig, S. \& Yahshilikov, Y., 2005. Interregional Integration of Wheat Markets in Kazakhstan. IAMO Discussion Paper Series, (88), pp.1-35.

Chapoto, A., 2012. The Political Economy of Food Price Policy: The Case of Zambia. UNU WIDER Working Paper, (100), pp.1-27.

Chirwa, E., 2001. Food pricing reforms and price transmission in Malawi: Implications for food policy and food security. University of Malawi Working

Paper Series, (4), pp.1-34.

Conforti, P., 2004. Price transmission in selected agricultural markets. FAO Commodity and Trade Policy Research Working Paper Series, (7), pp.1-91. Coxhead, I., Linh, V. \& Tam, L., 2012. Global market shocks and poverty in Vietnam: the case of rice. Agricultural Economics, 43(5), pp.575-592.

Dawson, P. \& Sanjua, A., 2006. Structural Breaks, the Export Enhancement Program and the Relationship between Canadian and US Hard Wheat Prices. Journal of Agricultural Economics, 57(1), pp.101-116.

Djuric, I., Götz, L. \& Glauben, T., 2011. Effects of the governmental market interventions on the wheat market in Serbia during the food crisis 2007 /

2008. In Annual Meeting of the German Society of Economic and Social Sciences in Agriculture (GEWISOLA), Halle, Germany. Halle, Germany, pp. 1-14. Dutoit, L., Hernandez-Villafuerte, K. \& Urrutia, C., 2009. Price transmission in Latin American maize and rice markets. ECLAC Working Paper, pp.1-47. 


\begin{tabular}{|c|c|}
\hline Study & obs. \\
\hline $\begin{array}{l}\text { Fabiosa, J.F., 2000. Impact of GATT in the Functioning of Agricultural Markets: An Examination of Market Integration and Efficiency in the World Beef } \\
\text { and Wheat Market under the pre-GATT and post-GATT Regimes. In Annual Meeting of the American Agricultural Economics Association (AAEA), } \\
\text { Tampa, United States. Tampa, Florida, USA, pp. 1-17. }\end{array}$ & 1 \\
\hline $\begin{array}{l}\text { Fiamohe, R. et al., 2013. Price transmission analysis using threshold models: an application to local rice markets in Benin and Mali. Food Security, 5(3), } \\
\text { pp.427-438. }\end{array}$ & 4 \\
\hline Franken, J. et al., 2005. Market Integration: Case Studies of Structural Change. Agricultural and Resource Economics Review, $32(2)$, pp.163-172. & 6 \\
\hline Getnet, K., 2007. Spatial Equilibrium of Wheat Markets in Ethiopia. African Development Review, 19(2), pp.281-303. & 1 \\
\hline $\begin{array}{l}\text { Getnet, K., Verbeke, W. \& Viaene, J., 2005. Modeling spatial price transmission in the grain markets of Ethiopia with an application of ARDL approach } \\
\text { to white teff. Agricultural Economics, 33(3, S), pp.491-502. }\end{array}$ & 1 \\
\hline Ghoshray, A. \& Ghosh, M., 2011. How Integrated is the Indian Wheat Market? Journal of Development Studies, 47(10), pp.1574-1594. & 8 \\
\hline $\begin{array}{l}\text { Ghoshray, A., 2008. Asymmetric Adjustment of Rice Export Prices : The Case of Thailand and Vietnam. International Journal of Applied Economics, } \\
\text { 5(September), pp.80-91. }\end{array}$ & 1 \\
\hline $\begin{array}{l}\text { Ghoshray, A., 2007. An examination of the relationship between US and Canadian durum wheat prices. Canadian Journal of Agricultural Economics, 55, } \\
\text { pp.49-62. }\end{array}$ & 1 \\
\hline $\begin{array}{l}\text { Gonzalez-Rivera, G. \& Helfand, S., 2001. The extent, pattern, and degree of market integration: A multivariate approach for the Brazilian rice market. } \\
\text { American Journal of Agricultural Economics, 83(August), pp.576-592. }\end{array}$ & 2 \\
\hline $\begin{array}{l}\text { Goodwin, B.K. \& Piggott, N.E., 2001. Spatial Market Integration in the Presence of Threshold Effects. American Journal of Agricultural Economics, 83(2), } \\
\text { pp.302-317. }\end{array}$ & 12 \\
\hline $\begin{array}{l}\text { Götz, L., Glauben, T. \& Brümmer, B., 2013. Wheat export restrictions and domestic market effects in Russia and Ukraine during the food crisis. Food } \\
\text { Policy, 38, pp.214-226. }\end{array}$ & 4 \\
\hline $\begin{array}{l}\text { Götz, L. et al., 2012. The Law of One Price under State-Dependent Policy Intervention: An Application to the Ukrainian Wheat Market. In Annual } \\
\text { Meeting of the Agricultural \& Applied Economics Association (AAEA), Seattle, United States. Seattle, Washington, USA, pp. 1-36. }\end{array}$ & 3 \\
\hline $\begin{array}{l}\text { Götz, L., Glauben, T. \& Brümmer, B., 2010. Impacts of Export Controls on Wheat Markets During the Food Crisis } 2007 / 2008 \text { in Russia and Ukraine. In } \\
\text { Annual Meeting of the Agricultural \& Applied Economics Association (AAEA), Denver, United States. Denver, Colorado, USA, pp. 1-22. }\end{array}$ & 4 \\
\hline $\begin{array}{l}\text { Goychuk, K. \& Meyers, W., 2011. Black Sea Wheat Market Integration with the International Wheat Markets: Some Evidence from Co-integration } \\
\text { Analysis. In Annual Meeting of the Agricultural \& Applied Economics Association (AAEA), Pittsburgh, United States. Pittsburgh, Pennsylvania, USA, pp. } \\
\text { 1-16. }\end{array}$ & 10 \\
\hline Greb, F. et al., 2012. Price transmission from international to domestic markets. GlobalFood Discussion Papers, 15, pp.1-48. & 497 \\
\hline Greb, F. et al., 2013. The estimation of threshold models in price transmission analysis. American Journal of Agricultural Economics, 95(4), pp.900-916. & 12 \\
\hline $\begin{array}{l}\text { Grethe, H. et al., 2012. How do World Agricultural Commodity Price Spikes Affect the Income Distribution in Israel? Annual Meeting of the German } \\
\text { Society of Economic and Social Sciences in Agriculture (GEWISOLA), Hohenheim, Germany, pp.1-13. }\end{array}$ & 2 \\
\hline
\end{tabular}




\begin{tabular}{|c|c|}
\hline Study & obs. \\
\hline Hai, T., 2003. Rice markets in the Mekong River Delta, Vietnam : A market integration analysis. CAS Discussion Paper Series, (40), pp.1-19. & 1 \\
\hline $\begin{array}{l}\text { Hernandez-Villafuerte, K., 2011. The relationship between spatial integration and geographical distance in Brazil. Annual Meeting of the European } \\
\text { Association of Agricultural Economics (EAAE), Zürich, Switzerland, pp.1-37. }\end{array}$ & 273 \\
\hline Huang, J., Yang, J. \& Rozelle, S., 2013. The political economy of food pricing policy in China. UNU-WIDER Working Paper Series, (38), pp.1-29. & 4 \\
\hline $\begin{array}{l}\text { Ihle, R., von Cramon-Taubadel, S. \& Zorya, S., 2011. Measuring the integration of staple food markets in Sub-Saharan Africa: Heterogeneous } \\
\text { infrastructure and cross border trade in the East African community. CESifo Working Paper, 3413, 1-33. }\end{array}$ & 86 \\
\hline Kirsten, J., 2012. The political economy of food price policy in South Africa. UNU-WIDER Working Paper Series, 102, pp.1-36. & 1 \\
\hline Li, Y. et al., 2010. LL601 contamination and its impact on US rice prices. Journal of Agricultural and Applied Economics, 42(1), pp.31-38. & 1 \\
\hline $\begin{array}{l}\text { Lutz, C., Tilburg, A. \& Kamp, B., 1995. The process of short-and long-term price integration in the Benin maize market. European Review of Agricultural } \\
\text { Economics, 22(1995), pp.191-212. }\end{array}$ & 4 \\
\hline $\begin{array}{l}\text { Lwin, H. et al., 2005. Market Integration Analysis in Selected Rice Markets of Myanmar. Journal of the Faculty of Agriculture, Kyushu University, 50(2), } \\
\text { pp.649-663. }\end{array}$ & 5 \\
\hline Minot, N., 2011. Transmission of World Food Price Changes to Markets in Sub-Saharan Africa. IFPRI Discussion Paper Series, 01059, pp.1-44. & 54 \\
\hline $\begin{array}{l}\text { Mohanty, S., Smith, D. \& Peterson, W., 1996. Time Series Evidence of Relationships Between US and Canadian Wheat Prices. lowa State University } \\
\text { Working Paper Series, 154, pp.1-19. }\end{array}$ & 4 \\
\hline $\begin{array}{l}\text { Mohanty, S. \& Langley, S., 2003. The Effects of Various Policy Regimes in the Integration of North American Grain Markets. Canadian Journal of } \\
\text { Agricultural Economics, 51(1), pp.109-120. }\end{array}$ & 4 \\
\hline $\begin{array}{l}\text { Mutuc, M., Pan, S. \& Hudson, D., 2011. Sino-US Price Transmission in Agricultural Commodities: How Important are Exchange Rate Movements? } \\
\text { Annual Meeting of the Agricultural and Applied Economics Association (AAEA), Pittsburgh, United States, pp.1-26. }\end{array}$ & 3 \\
\hline Nzuma, J., 2013. The political economy of food price policy: The case of Kenya. UNU-WIDER Working Paper Series, 26. & 5 \\
\hline $\begin{array}{l}\text { Pede, V. \& McKenzie, A., 2008. Integration In Benin Maize Market: An Application Of Threshold Cointegration Analysis. Journal of International } \\
\text { Agricultural Trade and Development, 5(1), pp.129-146. }\end{array}$ & 21 \\
\hline $\begin{array}{l}\text { Qiu, F., 2013. Dynamic impacts of export controls on price transmission. Annual Meeting of the Agricultural and Applied Economics Association (AAEA), } \\
\text { Washington, United States, pp.1-13. }\end{array}$ & 3 \\
\hline $\begin{array}{l}\text { Rapsomanikis, G. \& Hallam, D., 2006. Market integration and price transmission in selected food and cash crop markets of developing countries: } \\
\text { review and applications. In In: Commodity Market Review 2003-2004, FAO Commodities and Trade Division, Rome, Italy. pp. 51-76. }\end{array}$ & 1 \\
\hline Roche, M. \& McQuinn, K., 2003. Grain price volatility in a small open economy. European Review of Agriculture Economics, 30(1), pp.77-98. & 2 \\
\hline $\begin{array}{l}\text { Sanogo, I. \& Maliki Amadou, M., 2010. Rice market integration and food security in Nepal: The role of cross-border trade with India. Food Policy, 35(4), } \\
\text { pp.312-322. }\end{array}$ & 1 \\
\hline $\begin{array}{l}\text { Sharma, R., 2003. The transmission of world price signals: the concept, issues and some evidence from Asian cereal markets. In In: Agricultural Trade } \\
\text { and Poverty - Making Policy Analysis Count, OECD, Paris, France. pp. 141-160. }\end{array}$ & 24 \\
\hline
\end{tabular}


Thompson, S., Sul, D. \& Bohl, M., 2002. Spatial market efficiency and policy regime change: seemingly unrelated error correction model estimation.

American Journal of Agricultural Economics, 84(4 (November)), pp.1042-1053.

Thompson, S. \& Bohl, M., 1999. International wheat price transmission and CAP reform. Annual Meeting of the Agricultural \& Applied Economics

Association (AAEA), Nashville, United States, pp.1-20.

Vasciaveo, M., Rosa, F. \& Weaver, R., 2013. Agricultural market integration : price transmission and policy intervention. Annual Conference of the

Italian Association of Agricultural Economists (AIEAA), Parma, Italy, pp.1-27.

Yakhshilikov, Y. \& Brosig, S., 2006. Spatial price transmission in Kazakh wheat markets. In Conference of the International Association of Agricultural

Economists, Gold Coast, Australia. pp. 1-11.

Sum of observations 
Chapter Three 


\title{
Proximity and price co-movement in West African rice markets
}

\author{
Carolin Mengel, Stephan von Cramon-Taubadel ${ }^{18}$ \\ Department of Agricultural Economics and Rural Development \\ University of Göttingen
}

This paper is publicly available as GlobalFood Discussion Paper No. 38 on:

http://www.uni-goettingen.de/de/globalfood-discussion-paper-series/213486.html

The paper is a first draft and currently being revised for journal submission.

\footnotetext{
${ }^{18}$ Corresponding authors: Carolin Mengel (carolin.mengel@agr.uni-goettingen.de), Stephan von CramonTaubadel (scramon@gwdg.de). Carolin Mengel is a Research Associate with the GlobalFood Research Training Group and gratefully acknowledges funding by the German Research Foundation (DFG). We also thank the German Research Foundation (DFG) for the funding and the International Food Policy Research Institute (IFPRI) in Dakar for the feedback and the provided infrastructure. Moreover, we thank Maximo Torero, Tanguy Bernard, Ismael Fofana, Fousseini Traoré, Anatole Goundan, Jenny Aker and Dembo Kouyaté for useful feedback, support and assistance.
} 


\begin{abstract}
This study explores the link between proximity and price cointegration between two markets, where proximity is captured with variables for geographical, political and cultural distance. Linear and threshold cointegration is tested for a set of 756 rice market pairs in 6 West African countries, with threshold specifications accounting for transaction costs. Whether proximity influences price transmission is determined in a second step with a multinomial logistic regression. The estimation produces robust and statistically significant evidence of a link with air-line and road distance, international borders, contiguity and a common language. We conclude that proximity matters for market integration processes in West African rice markets.
\end{abstract}

JEL:

C32, D23, L11, Q11, Q17

\title{
Keywords:
}

West Africa, cointegration, developing countries, agricultural trade, rice, commodity prices, transaction costs, regional integration 


\section{Introduction}

The relationship between market proximity and integration is widely acknowledged in the trade volume literature. The closer two markets are in terms of geographical, political and cultural distance, the more they trade. However, the influence of proximity has not yet been clearly documented in the price transmission literature. Whether and how price signals are transmitted between markets may partly depend on geographical, political, cultural factors. This study proposes an approach to examine this link. We seek to identify the empirical determinants of commodity market integration.

We study rice markets in West Africa, where both imported and local rice are relevant staple crops and widely traded. The region is both with economically and politically relevant. West Africa is a food deficit area and local market integration plays an important role in cushioning shortages or food price shocks. Moreover, stabilizing local food production is a political goal in most West African countries, all of which were affected by high import prices in recent years. Net food importing countries are particularly vulnerable to global food price shocks. An improved understanding of price dynamics and market integration in the area can contribute to policy formulation regarding price interventions, infrastructure, border management and trade enhancing measures.

\section{Theory and literature}

Fackler and Goodwin (2001) define market integration as "the measure of the degree to which demand and supply shocks arising in one region are transmitted to another region". Price transmission analysis studies in particular price dynamics between markets reflecting such shocks. Price transmission may take place as a result of physical trade due to arbitrage, either directly or via third markets. It can also take place in the absence of trade flows as a result of communication or the flow of information (Jensen, 2007; Stephens et al., 2012).

Over time price transmission manifests itself as some sort of co-movement of prices in the respective markets. Since Ardeni (1989) this co-movement has overwhelmingly been modeled using cointegration techniques. In the case of price transmission between two geographically separated markets (spatial price transmission), so-called threshold error correction models (TVECMs) are commonly employed. The TVECM allows modelers to explicitly account for the costs of trade between two locations. If the prices differ by more than these costs, trade is triggered between the markets. Parts employ the TVECM to combine a band or regime of price transmission, within which prices co-move as a result of trade or information flows, with a neutral band within which prices move independently of one another (Greb et al., 2013). However, such a neutral band as the absence of price transmission is not a necessary requirement for the model. It is sufficient if price transmission changes significantly when the price change exceeds a certain threshold value. One possible explanation would be that individual trade costs for market actors differ and an increase in the profit margin attracts more competition spurring price transmission.

Whether and how prices on spatially separate markets move together is thus closely related to the costs of trade and communication between these markets. Definitions of these costs and the theoretical link with trade can be derived from trade literature. Anderson and Van Wincoop (2004) classify trade costs as (I) transportation costs such as gas and tolls, (II) trade barriers such as custom procedures and tariffs and (III) transaction costs such as long distance phone calls and translation. Gravity models explicitly link trade volumes to both size and proximity of markets. Proximity has a geographic dimension, but cultural similarities such as a shared language can also indicate a form of proximity. For the West African region, Zannou (2010) finds that commodity trade between markets falls with increasing distance between them and if they are separated by an international border. He also finds that a common official language and contiguity are positively correlated with trade volume. 
In this strand of the literature, the explanation given is that trade costs increase with distance and decrease commercial activity and communication. This link between distance/borders, trade costs, and trade volumes has been confirmed in many studies.

A related perspective on the link between prices and the proximity of markets can be derived from the literature on price disparities. A number of studies concern themselves with distance and border effects and deviations from the Law of One Price. The seminal paper by Engel and Rogers (1995) finds that a border has the same effect on price disparities as 2500 kilometers of distance. Similarly, Aker et al. (2013) finds a statistical link from borders to price disparities between markets Niger and Nigeria.

Very few studies have attempted to test whether proximity and borders affect not trade volumes or price differentials between markets, but rather whether there is price transmission between these markets. If proximity and borders affect trade and information flows between markets, then it is reasonable to expect that they will also affect the process of price transmission between these markets. Hernandez-Villafuerte (2011) finds a significant negative effect of road distance on the size of the cointegrating elasticity between Brazilian rice markets.

In a meta-analysis of the spatial price transmission literature, (Mengel \& von Cramon-Taubadel, 2014) find that geographic distance and separation by an international border affect the likelihood of cointegration between the prices on two markets. According to the results, the likelihood of cointegration is $23 \%$ lower if the markets in question are separated by an international border. Furthermore, each additional 1000 kilometer distance between two markets within a country decreases the likelihood of cointegration by $7 \%$. The authors use meta-analysis to take advantage of the extensive empirical literature on price transmission to test for distance and border effects. However, meta-analysis is made difficult by the fact that different price transmission studies use different estimation approaches and different types of data, with the result that their findings are not always directly comparable. Furthermore, meta-analysis is susceptible to publication bias in the literature it evaluates, and to often incomplete documentation of methods and results in published studies. Hence, the aim of this paper is to complement the meta-analysis in Mengel and von CramonTaubadel (2014) with empirical estimates of distance and border effects in price transmission. To this end we test for the presence of distance and border effects on the transmission of rice prices between markets in Western Africa.

\section{Methods and data}

We employ 28 monthly rice price series from Benin, Mauretania, Niger, Chad, Senegal and Togo. We consider only pairs of prices for imported rice. Research has demonstrated that local and imported rice varieties are not close substitutes (Demont et al., 2013a; Matty Demont et al., 2013b). The resulting product heterogeneity might confound the effects we want to isolate. We restrict the analysis to series with at least 100 observations and less than $10 \%$ missing values. The price series are taken from the FAO-GIEWS, USDA-FEWS and UN-WFP VAM databases. Most of the series start in the early 2000s and end in 2012 or 2013. The markets considered are retail markets with the exception of one wholesale market in Niger (Maradi2, see Table 1). To ensure comparability we convert all series into CFA (XOF) and per kilogram terms. Individual plots of the price series are provided in the Appendix. 
Table 1: Descriptive statistics and unit-root tests of price series

\begin{tabular}{|c|c|c|c|c|c|c|c|}
\hline Series label & Country & Start & End & $\begin{array}{l}\text { Missing } \\
\text { values }\end{array}$ & $\begin{array}{l}\text { t-stat ADF } \\
\text { (level) }\end{array}$ & $\begin{array}{l}\text { t-stat } \\
\text { ADF } \\
\text { (diff) }\end{array}$ & \\
\hline Abomey & Benin (BEN) & Aug 95 & Oct 13 & $6.8 \%(15)$ & 0.754 & -11.964 & $* * *$ \\
\hline Cotonou & Benin (BEN) & May 95 & Oct 13 & - & 1.198 & -13.101 & $* * *$ \\
\hline Natitingou & Benin (BEN) & May 95 & Oct 13 & $3.6 \%(8)$ & 0.887 & -11.556 & $* * *$ \\
\hline Moussoro1 & Chad (TCD) & Oct 03 & Oct 13 & - & 0.096 & -13.070 & $* * *$ \\
\hline NDjamena1 & Chad (TCD) & Oct 03 & Oct 13 & - & -0.170 & -11.065 & $* * *$ \\
\hline Moussoro2 & Chad (TCD) & Jan 02 & Jun 13 & - & -0.103 & -12.252 & $* * *$ \\
\hline NDjamena4 & Chad (TCD) & Jan 02 & Jun 13 & - & -0.062 & -12.056 & $* * *$ \\
\hline Nouakchott1 & Mauritania (MRT) & Oct 03 & Oct 13 & $5.8 \%(7)$ & 0.088 & -7.161 & $* * *$ \\
\hline Nouakchott2 & Mauritania (MRT) & Apr 03 & Jun 13 & $4.1 \%(5)$ & 0.161 & -9.533 & $* * *$ \\
\hline Agadez1 & Niger (NER) & May 95 & Apr 12 & - & 1.198 & -11.579 & $* * *$ \\
\hline Dosso & Niger (NER) & May 95 & Apr 12 & $2 \%(4)$ & 0.970 & -11.309 & $* * *$ \\
\hline Maradi1 & Niger (NER) & May 95 & Apr 12 & - & 1.209 & -11.058 & $* * *$ \\
\hline Niamey1 & Niger (NER) & Jan 00 & Apr 12 & - & 0.732 & -9.190 & $* * *$ \\
\hline Zinder1 & Niger (NER) & Jan 00 & Apr 12 & - & 1.551 & -9.680 & $* * *$ \\
\hline Agadez2 & Niger (NER) & Jan 02 & Jun 13 & $0.7 \%(1)$ & 1.020 & -8.132 & $* * *$ \\
\hline Maradi2 & Niger (NER) & Oct 03 & Jun 13 & - & 1.098 & -8.018 & $* * *$ \\
\hline Niamey2 & Niger (NER) & Oct 03 & Jun 13 & - & 0.683 & -9.014 & $* * *$ \\
\hline Zinder2 & Niger (NER) & Oct 03 & Jun 13 & - & 1.343 & -9.142 & $* * *$ \\
\hline Dakar & Senegal (SEN) & Oct 03 & Jun 13 & - & -0.095 & -9.310 & $* * *$ \\
\hline Kaolack & Senegal (SEN) & Oct 03 & Jun 13 & - & -0.068 & -8.459 & $* * *$ \\
\hline StLouis & Senegal (SEN) & Oct 03 & Jun 13 & - & -0.128 & -7.562 & $* * *$ \\
\hline Ziguinchor & Senegal (SEN) & Oct 03 & Jun 13 & - & -0.039 & -7.066 & $* * *$ \\
\hline Amegnran & Togo (TGO) & Jan 01 & Nov 13 & - & 0.441 & -13.020 & $* * *$ \\
\hline Anie & Togo (TGO) & Jan 01 & Nov 13 & - & -0.012 & -11.648 & $* * *$ \\
\hline Cinkasse & Togo (TGO) & Jan 01 & Nov 13 & - & 0.472 & -11.831 & $* * *$ \\
\hline Kara & Togo (TGO) & Jan 01 & Nov 13 & - & 0.242 & -11.774 & $* * *$ \\
\hline Korbongou & Togo (TGO) & Jan 01 & Nov 13 & $1.9 \%(3)$ & 0.347 & -12.227 & $* * *$ \\
\hline Lome & Togo (TGO) & Jan 01 & Nov 13 & - & -0.054 & -10.765 & $* * *$ \\
\hline
\end{tabular}

Note: Augmented Dickey-Fuller test statistics are presented for the series in levels and in first differences. Critical value for the null hypothesis of a unit root is -1.95 for a $5 \%$ level of significance. Results indicate non-stationarity of all series at the $1 \%$ level.

We linearly interpolate all missing values. After interpolation, all of the series contain between 105 and 222 observations and cover between 8 and 18 years. The Augmented Dickey Fuller test (Dickey \& Fuller, 1979) fails to reject the null-hypothesis of a unit root in all of the price series in levels, but rejects this null-hypothesis for all of the series in first differences (Table 1). Table 2 lists the different tests and hypotheses used on univariate and bivariate price series. 
Table 2: Linear and nonlinear cointegration tests applied to the West African rice prices

\begin{tabular}{lll}
\hline Author & H0: & H1: \\
\hline Johansen (1988) & no cointegration & linear cointegration \\
Hansen \& Seo (2002) & linear cointegration & threshold cointegration (2 regime TVECM) \\
Seo (2006) & no cointegration & threshold cointegration (BAND-TVECM) \\
Larsen (2012) & linear cointegration & 2 threshold cointegration (3 regime TVECM) \\
\hline \hline
\end{tabular}

Note: The tests were implemented with the statistical software $R$ and the R-packages urca and tsDyn and test results were obtained at the $5 \%$ level of significance.

The 28 price series are combined to form market pairs for the subsequent analysis. In each pair one or both price series are trimmed to the same length. This results in 378 bivariate market pairs, of which 311 are separated by an international border and 67 are domestic price pairs from one of the sample countries. We test each price pair for linear and threshold cointegration (Table 2). The term threshold cointegration can be misleading because it suggests some sort of nonlinear cointegrating relationship, for example as proposed by Gonzalo and Pitarakis (2006). However, it is an established term in the literature for describing linear cointegration with threshold effects in the adjustment. ${ }^{19}$ Hereafter, we will use it in the same way.

The threshold cointegration test results are sensitive to the order of the two price components. Each price pair is therefore tested a second time in reverse order, thus producing an overall sample of 756 observations. For all tests, the number of lags is selected according to the Bayesian information criterion (BIC). We use the Johansen test (Johansen, 1988) to test for linear cointegration. To carry out this test we restrict the cointegrating vector to equal $[1,-1]$ and include no constant in the longrun relationship. Since linear cointegration cannot account for trade costs in spatial price transmission, we also use three tests for threshold cointegration. First, the Hansen \& Seo test tests the null-hypothesis of linear cointegration against the alternative of threshold cointegration with one threshold. In other word, the rejection of the null indicates superiority of a two-regime TVECM compared to a linear VECM specification. We also use an extended Hansen \& Seo test proposed by Larsen (2012) that allows for two possibly asymmetric thresholds. This TVECM specification has been used in recent studies (Greb et al., 2013) and is able to account for possible asymmetry in transaction costs depending on the direction of trade. Finally, we also employ a test developed by Seo (2006) which tests the null hypothesis of no cointegration against the alternative hypothesis of threshold cointegration. Together, these four tests cover the variety of model specifications that are currently and commonly employed in the spatial price transmission literature.

Using the results of these tests we explore the link between proximity and cointegration between two prices using the following basic specification:

$$
\text { Cointegration }=f(\text { proximity })
$$

The specification of the covariates that measure proximity in equation (1) is based on the theoretical considerations discussed above, the literature on the determinants of trade volumes, and the literature on distance and border effects. To measure the physical distance between two markets, both air-line distance and road distance measures are chosen. These are obtained with an online distance calculator (www.distance.to), based on Google maps API. For the estimation, physical distance is measured in $1000 \mathrm{~km}$. All remaining covariates are obtained from Mayer and Zignago (2011) often referred to as CEPII data set. The two variables for borders and contiguity distinguish between the presence of at least one international border between two markets (border $=1$ ), and whether the two countries in question share this border (contiguity $=1$ ). Hence, the border dummy

\footnotetext{
${ }^{19}$ Gonzalo and Pitarakis (2006) propose a model that includes threshold effects in the cointegrating relationship between two variables, rather than in the corresponding error correction mechanism.
} 
takes the value 0 for market pairs located in the same country and 1 otherwise, and as a subset of those cases for which border $=1$, the contiguity dummy takes the value 1 if the countries in question are direct neighbors. All other things being equal, trade between neighboring countries will be facilitated by established trade routes, including perhaps smuggling, compared with trade across two or more borders. As measures of cultural proximity we include a dummy variable that equals one if the countries in question share a language.

Table 3: Summary statistics of market pair variables

\begin{tabular}{llllll}
\hline Variable & $\mathbf{N}$ & Mean & St. Dev. & Min & Max \\
\hline linear cointegration & 756 & 0.247 & 0.432 & 0 & 1 \\
threshold cointegration & 756 & 0.263 & 0.441 & 0 & 1 \\
$\mathbf{1 0 0 0}$ km air-line distance & 756 & 1.407 & 0.952 & 0.00 & 3.658 \\
1000 km road distance & 756 & 1.900 & 1.276 & 0.00 & 4.922 \\
Border (yes = 1, otherwise 0) & 756 & 0.823 & 0.382 & 0 & 1 \\
Contiguity (yes = 1, otherwise 0) & 756 & 0.235 & 0.425 & 0 & 1 \\
same language (yes = 1, otherwise 0) & 756 & 0.754 & 0.431 & 0 & 1 \\
\hline \hline
\end{tabular}

Note: Air-line and road distance were obtained with the online distance calculator

www.distance.to. Contiguity and same official or ethnological language are variables obtained from Mayer and Zignago (2011).

There is collinearity in this set of covariates. First, market pairs that are geographically proximate are more likely to be located in the same country (border $=0$ ). Second, countries in West Africa that were colonies of the same foreign power are more likely to share a common language. Third, the language variable is measured at the country level (Mayer \& Zignago, 2011) and consequently takes the same value (language $=1$ ) for all domestic market pairs (border $=0$ ). These correlations can influence parameter estimates and need to be kept in mind when interpreting the results presented in the next section.

\section{Results}

\subsection{Results of linear and threshold cointegration tests}

Table 4 provides an overview of the prevalence of linear and threshold cointegration between the domestic and cross-border market combinations. In some combinations, more price pairs show linear than threshold cointegration, while for others it is the other way around. A few examples illustrate this in more detail. In Benin all six possible pairs of domestic prices appear to be linearly cointegrated, but only two exhibit threshold effects in the adjustment. Hence, there is evidence that the magnitude of the deviation influences the speed of price transmission in only two of these pairs. As explained above, such a switch of the price adjustment regime is usually attributed to the role of trade costs. In all other pairs it appears that deviations from the long-run equilibrium are corrected with comparable speed, regardless of their magnitude. In the case of Senegal and Benin, none of the 12 market pairs appears to be linearly cointegrated, but in three pairs there is evidence of error correction if price differences exceed a threshold value. Whether and how proximity and borders influence these results is examined in the next section. 
Table 4: Share and number of linearly cointegrated (LC) and threshold cointegrated (TC) market pairs by countries

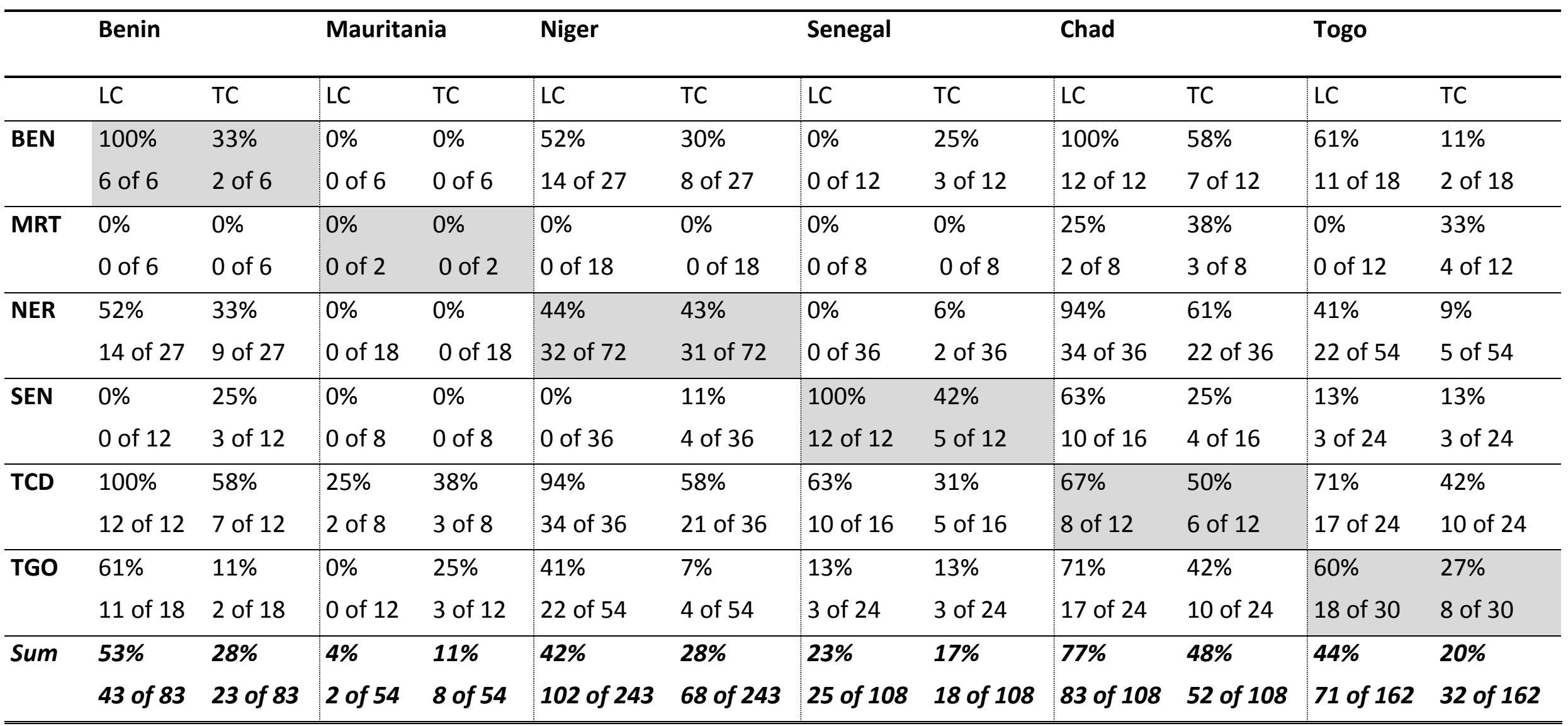

Note: LC stands for linear cointegration and TC for threshold cointegration. Price pairs can display evidence of both linear and threshold cointegration without contradiction. The percentage share refers to the market pairs tested positively for linear or threshold cointegration, e.g. 0 out of 12 Senegalese-Beninese market pairs are linearly cointegrated (0\%) and 3 out of 12 (or 25\%) are threshold cointegrated. The results are not necessarily symmetric as test results can differ in finite samples depending on the order of the two prices in a pair. 


\subsection{The influence of proximity and borders on the prevalence of cointegration}

To facilitate the estimation of the model in equation (1), we code the cointegration test results presented above into three categories. Each price pair is either not cointegrated (48.9\%), linearly cointegrated (24.7\%) or threshold cointegrated (26.3\%). We assign those market pairs for which tests find both linear and threshold cointegration to the threshold cointegration group. This is based on the formulation of the Hansen \& Seo test (2002) and the Larsen test (2012) of threshold cointegration against the alternative hypothesis of linear cointegration which indicates that the more flexible threshold cointegration model fits the adjustment process more precisely.

Hence, the dependent variable on the left-hand-side of equation (1) is a qualitative variable that can take on three values. We estimate this model using multinomial logistic regression. An ordered logit would not be suitable since the three categories form no genuine order. The estimated marginal effects can be interpreted as the increasing or decreasing likelihood (in \%) that a market pair belongs to one category rather than to the base. Since the base outcome is no cointegration, positive marginal effects can be interpreted as evidence of the increasing likelihood of some form of cointegration and, thus, price co-movement.

In Table 5 we first present results for all market pairs, both domestic and cross-border. In Table 6 we present results exclusively for the cross-border market pairs. We repeat the analysis exclusively for the cross-border pairs because one of the dummies variables for proximity (language) naturally always equal 1 for all domestic market pairs. ${ }^{20}$

\footnotetext{
${ }^{20}$ The regressions were also estimated with country dummies, but these proved to be highly collinear with the covariates for proximity and borders.
} 
Table 5: Marginal effects according to the multinomial logistic estimation with national and international market pairs

\begin{tabular}{|c|c|c|c|c|c|c|}
\hline & (1) & (1a) & (2) & (2a) & (3) & (4) \\
\hline linear cointegration: & $-0.122^{* *}$ & $-0.096^{*}$ & & & & \\
\hline $1000 \mathrm{~km}$ air-line distance & (0.017) & $(0.029)$ & & & & \\
\hline threshold cointegration: & $-0.041^{* *}$ & $-0.072^{* * *}$ & & & & \\
\hline $1000 \mathrm{~km}$ air-line distance & $(0.017)$ & $(0.023)$ & & & & \\
\hline linear cointegration: & & & $-0.091^{* * *}$ & $-0.071^{* * *}$ & & \\
\hline $1000 \mathrm{~km}$ road distance & & & $(0.013)$ & $(0.023)$ & & \\
\hline threshold cointegration: & & & $-0.030^{* *}$ & $-0.055^{* * *}$ & & \\
\hline $1000 \mathrm{~km}$ road distance & & & $(0.012)$ & $(0.018)$ & & \\
\hline linear cointegration: & & & & & $-0.108^{* * *}$ & $-0.137^{* * *}$ \\
\hline border & & & & & $(0.044)$ & $(0.047)$ \\
\hline threshold cointegration: & & & & & $-0.152^{* * *}$ & $-0.184^{* * *}$ \\
\hline border & & & & & $(0.045)$ & $(0.048)$ \\
\hline linear cointegration: & & & & & & $0.154^{* * * *}$ \\
\hline contiguity & & & & & & $(0.042)$ \\
\hline threshold cointegration: & & & & & & $0.160^{* * *}$ \\
\hline contiguity & & & & & & $(0.042)$ \\
\hline country dummies & & Yes & & Yes & & \\
\hline Observations & 756 & 756 & 756 & 756 & 756 & 756 \\
\hline Pseudo- $R^{2}$ & 0.055 & 0.212 & 0.054 & 0.212 & 0.020 & 0.058 \\
\hline Log Likelihood & -747.744 & -623.177 & -748.159 & -623.422 & -775.798 & -745.627 \\
\hline LR chi2(2) & $\begin{array}{l}86.95^{* * *} \\
(\mathrm{df}=2)\end{array}$ & $\begin{array}{l}336.08^{* * *} \\
(d f=12)\end{array}$ & $\begin{array}{l}86.12^{* * *} \\
(d f=2)\end{array}$ & $\begin{array}{l}335.59^{* * *} \\
(d f=12)\end{array}$ & $\begin{array}{l}30.84^{* * *} \\
(d f=2)\end{array}$ & $\begin{array}{l}91.18^{* * *} \\
(\mathrm{df}=4)\end{array}$ \\
\hline
\end{tabular}

Note: Base outcome is no cointegration according to the tests. Rather than coefficients, average marginal effects of a multinomial logistic estimation are reported, with standard errors in brackets. *, ** and ${ }^{* * *}$ refer to significance at the $10 \%, 5 \%$ and $1 \%$ levels, respectively.

Table 5 shows that distance has a negative effect on the likelihood of linear error correction, and a similar but somewhat weaker effect on the likelihood of threshold error correction. The magnitudes of these effects are somewhat stronger for air compared with road distance. Specifically, linear cointegration of two prices becomes $12.2 \%$ less likely with each additional 1000 kilometer geodesic distance. Threshold cointegration becomes $4.1 \%$ less likely. The inclusion of country dummies into the model reduces the magnitude of the first effect to $-9.6 \%$, and increases the magnitude of the second to $-7.2 \%$.Table 5 also shows that the likelihood of linear or threshold error correction falls if the markets in question are separated by an international border, and increases if the countries in question are contiguous. Prices are $10.8 \%$ less likely to display cointegration with linear error correction and $15.2 \%$ less likely to display cointegration with threshold error correction if they are recorded on markets that are separated by an international border. For contiguous countries, an overland transport route might be possible while countries without a common border require either transit through third countries or sea transport. The border effect becomes almost three percentage points stronger and more distinct if we control for contiguity of the countries. Contiguity itself increases the likelihood of both forms of cointegration by $15.4 \%$ and $16.0 \%$, respectively.

The second sample includes only cross-border market pairs to control for possible multicollinearity between border and language variables, as previously explained. 
Table 6: Results of multinomial logistic estimation with international market pairs

\begin{tabular}{|c|c|c|c|c|c|c|c|c|}
\hline & (5) & (5a) & (6) & (6a) & (7) & (7a) & $(8)$ & (8a) \\
\hline linear cointegration: & $-0.138^{* * *}$ & $-0.108^{* *}$ & & & & $-0.130^{* * *}$ & & $-0.138^{* * *}$ \\
\hline 1000 km air-line distance & (0.019) & $(0.043)$ & & & & $(0.024)$ & & (0.019) \\
\hline threshold cointegration: & -0.017 & -0.033 & & & & $0.060^{* *}$ & & -0.015 \\
\hline 1000 km air-line distance & $(0.018)$ & $(0.029)$ & & & & $(0.024)$ & & $(0.018)$ \\
\hline linear cointegration: & & & $-0.103^{* * *}$ & $-0.073^{* *}$ & & & & \\
\hline $1000 \mathrm{~km}$ road distance & & & (0.014) & $(0.034)$ & & & & \\
\hline threshold cointegration: & & & -0.013 & -0.030 & & & & \\
\hline $1000 \mathrm{~km}$ road distance & & & $(0.014)$ & $(0.022)$ & & & & \\
\hline linear cointegration: & & & & & $0.168^{* * *}$ & -0.005 & & \\
\hline contiguity & & & & & $(0.040)$ & $(0.040)$ & & \\
\hline threshold cointegration: & & & & & $0.173^{* * *}$ & $0.265^{* * *}$ & & \\
\hline contiguity & & & & & $(0.040)$ & $(0.055)$ & & \\
\hline linear cointegration: & & & & & & & $0.250^{* * * *}$ & $0.249^{* * *}$ \\
\hline same language & & & & & & & $(0.018)$ & (0.017) \\
\hline threshold cointegration: & & & & & & & $0.111^{* *}$ & $0.111^{* *}$ \\
\hline same language & & & & & & & $(0.051)$ & $(0.050)$ \\
\hline country dummies & & Yes & & Yes & & & & \\
\hline Observations & 622 & 622 & 622 & 622 & 622 & 622 & 622 & 622 \\
\hline Pseudo- $R^{2}$ & 0.051 & 0.246 & 0.050 & 0.245 & 0.048 & 0.074 & 0.030 & 0.083 \\
\hline Log Likelihood & -597.68 & -475.01 & -598.20 & -475.27 & -599.68 & -583.31 & -611.06 & -577.52 \\
\hline LR chi2(2) & $\begin{array}{l}64.35^{* * *} \\
(\mathrm{df}=2)\end{array}$ & $\begin{array}{l}309.70^{* * *} \\
(d f=12)\end{array}$ & $\begin{array}{l}63.31^{* * *} \\
(\mathrm{df}=2)\end{array}$ & $\begin{array}{l}309.16^{* * *} \\
(\mathrm{df}=12)\end{array}$ & $\begin{array}{l}60.34^{* * *} \\
(\mathrm{df}=2)\end{array}$ & $\begin{array}{l}93.10^{* * *} \\
(d f=4)\end{array}$ & $\begin{array}{l}37.58^{* * *} \\
(\mathrm{df}=2)\end{array}$ & $\begin{array}{l}104.67^{* * *} \\
(d f=4)\end{array}$ \\
\hline \multicolumn{9}{|c|}{$\begin{array}{l}\text { Note: Base outcome is no cointegration according to the tests. Rather than coefficients, average marginal effects of a multinomial logistic estimation } \\
\text { are reported, with standard errors in brackets. } *, * * \text { and } * * * \text { refer to significance at the } 10 \%, 5 \% \text { and } 1 \% \text { levels, respectively. Detailed results fo } \\
\text { intercepts and country variables are omitted from the table but can be found in the appendix. The regressions } 7,7 a, 8 \text { and } 8 \text { a were also estimated }\end{array}$} \\
\hline
\end{tabular}


The results in Table 6 confirm that the likelihood of linear and the likelihood of threshold error correction both fall with increasing distance between the markets in question. The effect of $1000 \mathrm{~km}$ of additional distance is between -10.8 and $-13.8 \%$ in all specifications and thus appears to be estimated robustly. However, distance has no significant effect on the likelihood of threshold error correction. Contiguity has a positive effect of $16.8 \%$ on the probability of linear cointegration and of $17.3 \%$ on the probability of threshold cointegration. When the air-line distance is included in the estimation, the effect of contiguity on the likelihood of linear cointegration becomes insignificant. This is presumably due to the collinearity between distance and contiguity. A common language has as expected a positive effect on linear cointegration (25.0\%) and to a smaller extent also on threshold cointegration (11.1\%). The inclusion of airline-distance into the equation does not change the magnitude of this effect.

Overall, linear cointegration is more prevalent when markets are closer in terms of geographical distance, linguistic and historical proximity. Threshold cointegration and geographical distance exhibit no statistically robust relationship, but border and language variables affect its likelihood in the sample.

\section{Discussion}

Generally the previously formulated hypothesis is supported by the evidence. Proximity does matter for whether rice prices in spatially separated markets are linearly or threshold cointegrated. The results are clear and statistically significant. This is the case although statistical testing naturally involves type I and type II errors resulting in false assignment of the observations to the three specified groups.

Some further caveats of the study are to be mentioned. The presence of multicollinearity of some of the variables is a noteworthy issue. We expect language to increase price transmission ceteris paribus but in the region, language is correlated with distance. Geographically proximate countries are more likely to be linguistically proximate. This makes it hard to separate their effects. Moreover, few data for West African countries are available thus limiting the number of countries in our study. Extending the analysis to a world-wide data set similar to the scope of gravity trade studies could be a worthwhile endeavor in the future. Typical for price transmission studies is the potential selection bias arising from limited data availability. Small or isolated markets are less likely to be included in big international data sets. We expect that these markets are also systematically less likely to be cointegrated with other markets. The data sets come from countries that participate in these international market information systems, generally countries with better infrastructure and institutions. Distance will presumably have a smaller effect on trade and price transmission in such countries.

Future research could study the effect of distance on the speed of price adjustment. Moreover, one could include an additional variable for policies. Countries that employ difference rice market policy tools are less likely to be characterized by rice price co-movement. Two countries that impose a tariff at their borders will have rice prices that move in parallel, but if one country uses a tariff and the other an import quota, their prices will be less likely to co-move. Future studies could also take a closer look at the difference of the border effects for neighboring countries and countries that do not share a common border. 


\section{References}

Aker, J., Klein, M., Connell, S., \& Yang, M. (2013). Borders, Ethnicity and Trade. Tufts University Working Paper Series, 1-72.

Anderson, J., \& Van Wincoop, E. (2004). Trade costs. Journal of Economic Literature, 42(3), 691-751.

Demont, M., Rutsaert, P., Ndour, M., \& Verbeke, W. (2013). Reversing Urban Bias in African Rice Markets: Evidence from Senegal. World Development, 45, 63-74.

Demont, M., Rutsaert, P., Ndour, M., Verbeke, W., Seck, P., \& Tollens, E. (2013). Experimental auctions, collective induction and choice shift: willingness-to-pay for rice quality in Senegal. European Review of Agricultural Economics, 40, 1-26.

Dickey, D., \& Fuller, W. (1979). Distribution of the estimators for autoregressive time series with a unit root. Journal of the American Statistical Association, 74(366), 427-431.

Engel, C., \& Rogers, J. (1995). How wide is the border? International Finance Discussion Papers, 498, $1-40$.

Fackler, P. L., \& Goodwin, B. K. (2001). Spatial price analysis. Handbook of Agricultural Economics, Volume 1, 971-1024.

Gonzalo, J., \& Pitarakis, J.-Y. (2006). Threshold Effects in Cointegrating Relationships. Oxford Bulletin of Economics and Statistics, 68, 813-833.

Greb, F., von Cramon-Taubadel, S., Krivobokova, T., \& Munk, A. (2013). The estimation of threshold models in price transmission analysis. American Journal of Agricultural Economics, 95(4), 900916.

Hansen, B., \& Seo, B. (2002). Testing for two-regime threshold cointegration in vector errorcorrection models. Journal of Econometrics, 110(2), 293-318.

Hernandez-Villafuerte, K. (2011). The relationship between spatial integration and geographical distance in Brazil. Annual Meeting of the European Association of Agricultural Economics (EAAE), Zürich, Switzerland, 1-37.

Jensen, R. (2007). The digital provide: Information (technology), market performance, and welfare in the South Indian fisheries sector. The Quarterly Journal of Economics, CXXII (3), 879-924.

Johansen, S. (1988). Statistical analysis of cointegration vectors. Journal of Economic Dynamics and Control, 12, 231-254.

Larsen, B. (2012). A threshold cointegration analysis of Norwegian interest rates. Master's Thesis in Statistics, University of Tromso., 1-141.

Mayer, T., \& Zignago, S. (2011). Notes on CEPII's distances measures: The GeoDist database. CEPII Working Paper Series, 25, 1-24. 
Mengel, C., \& von Cramon-Taubadel, S. (2014). Distance and border effects on price transmission - a meta-analysis. GlobalFood Discussion Papers.

Seo, M. (2006). Bootstrap testing for the null of no cointegration in a threshold vector error correction model. Journal of Econometrics, 134(1), 129-150.

Stephens, E., Mabaya, E., von Cramon-Taubadel, S., \& Barrett, C. (2012). Spatial Price Adjustment with and without Trade. Oxford Bulletin of Economics and Statistics, 74(3), 453-469.

Zannou, A. (2010). Determinants of intra-ECOWAS trade flows. African Journal of Business Management, 4, 678-686. 


\section{Appendix}

Figure 2: Plots of price series
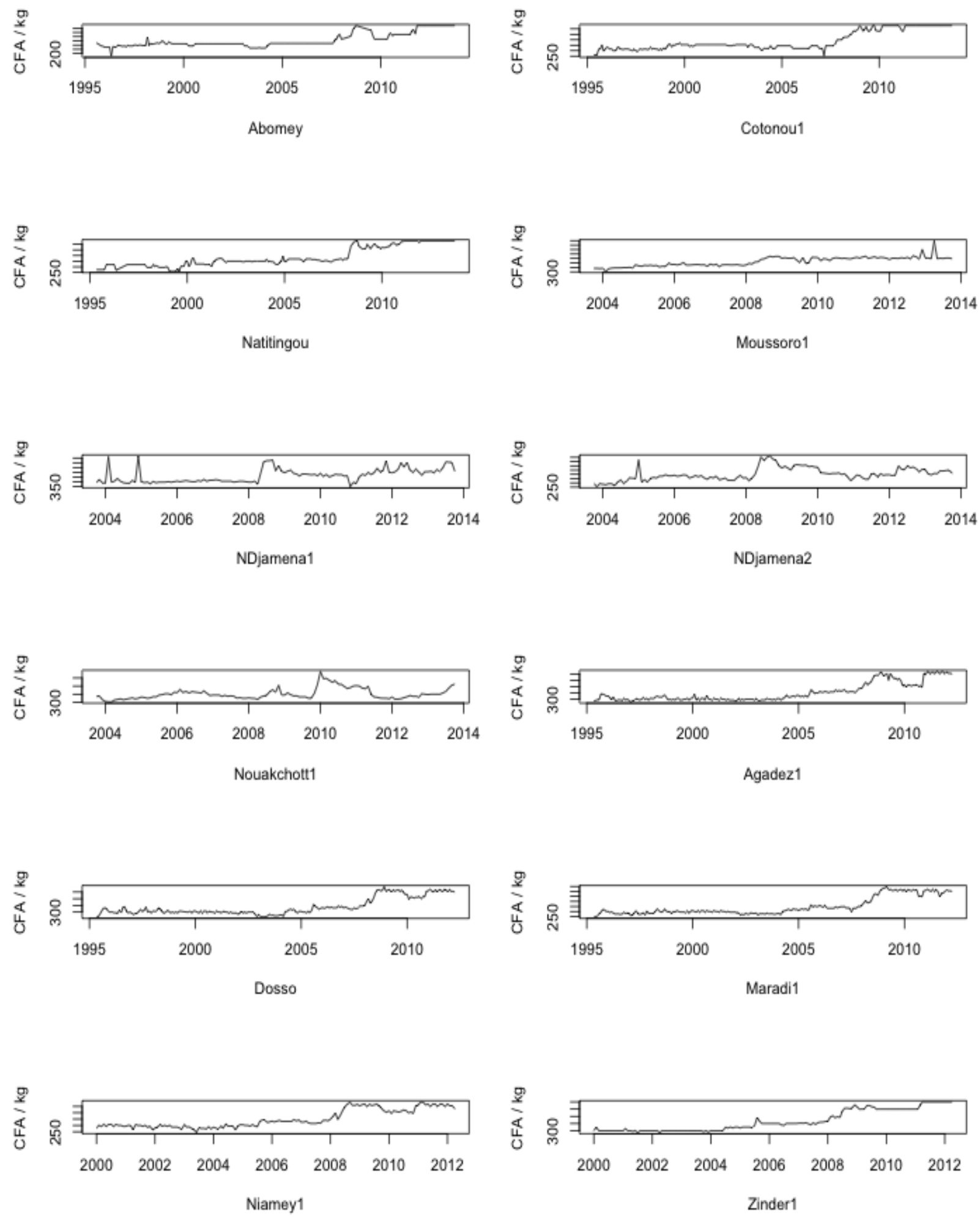


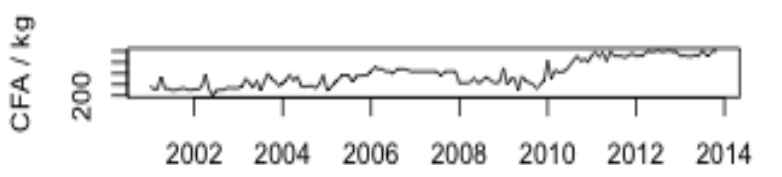

Amegnran
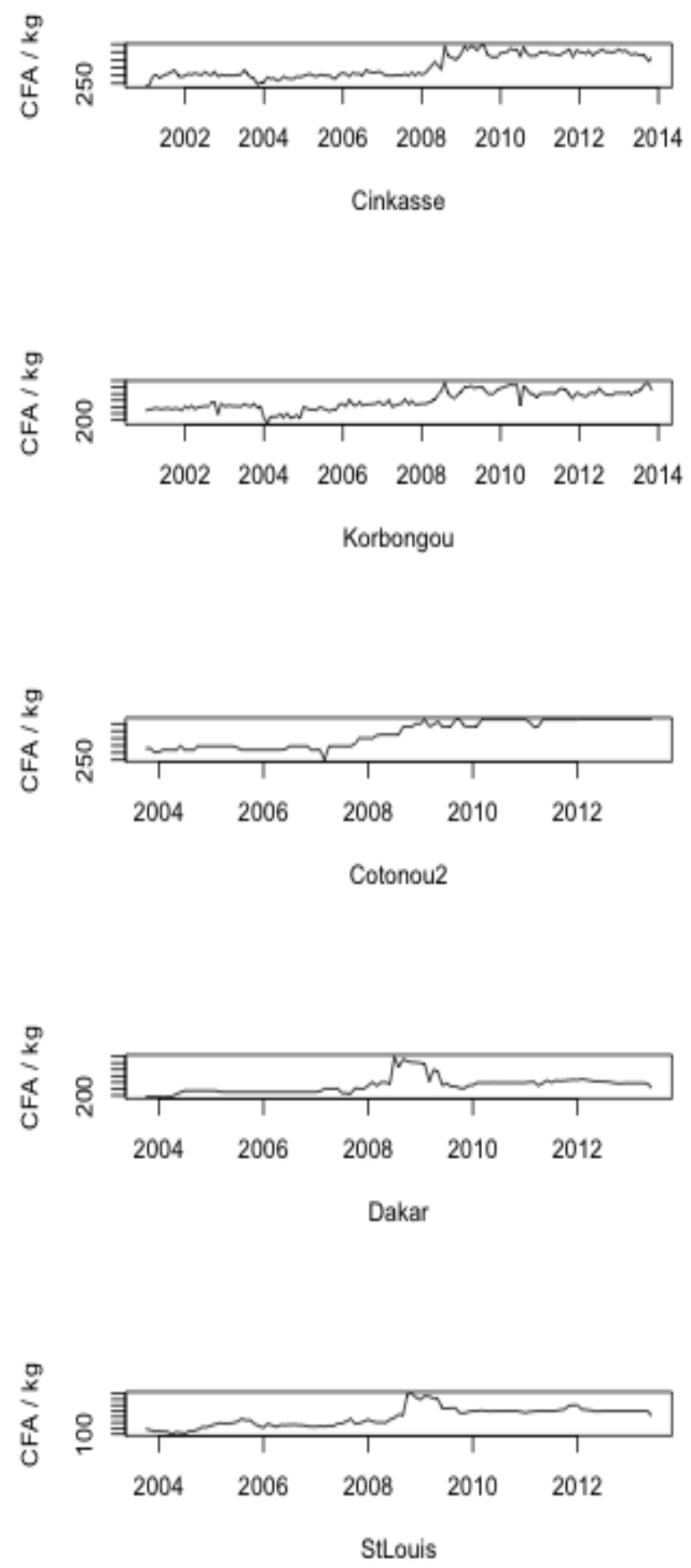
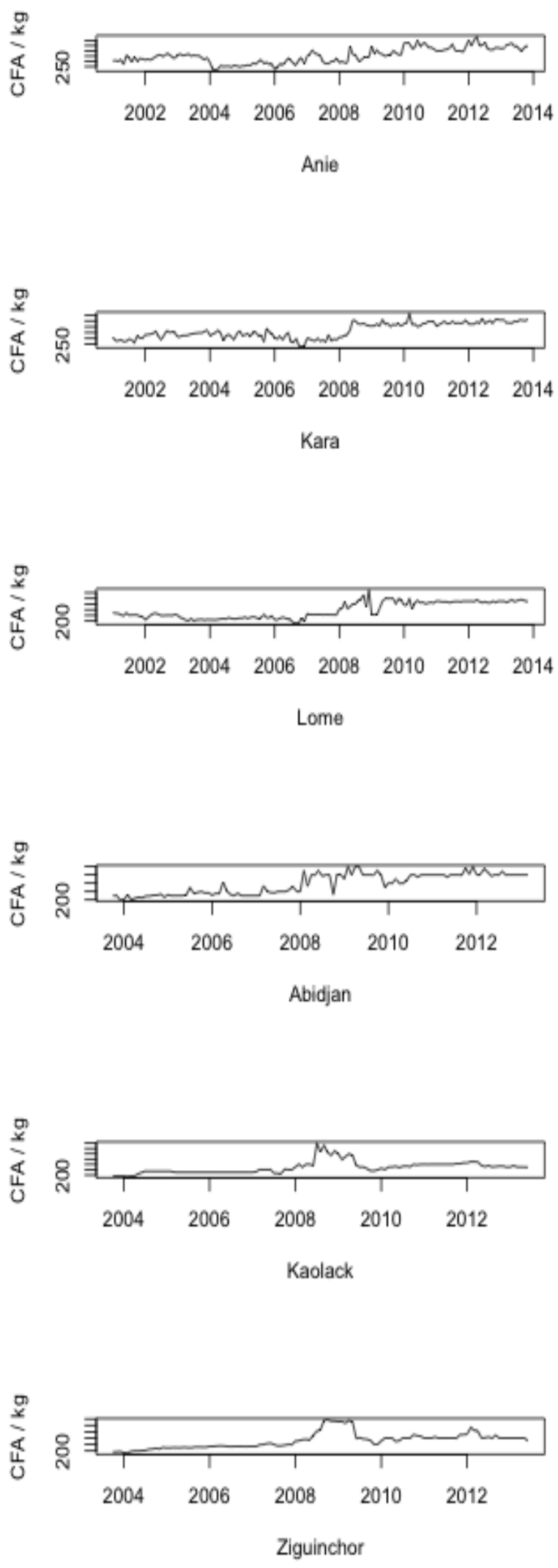

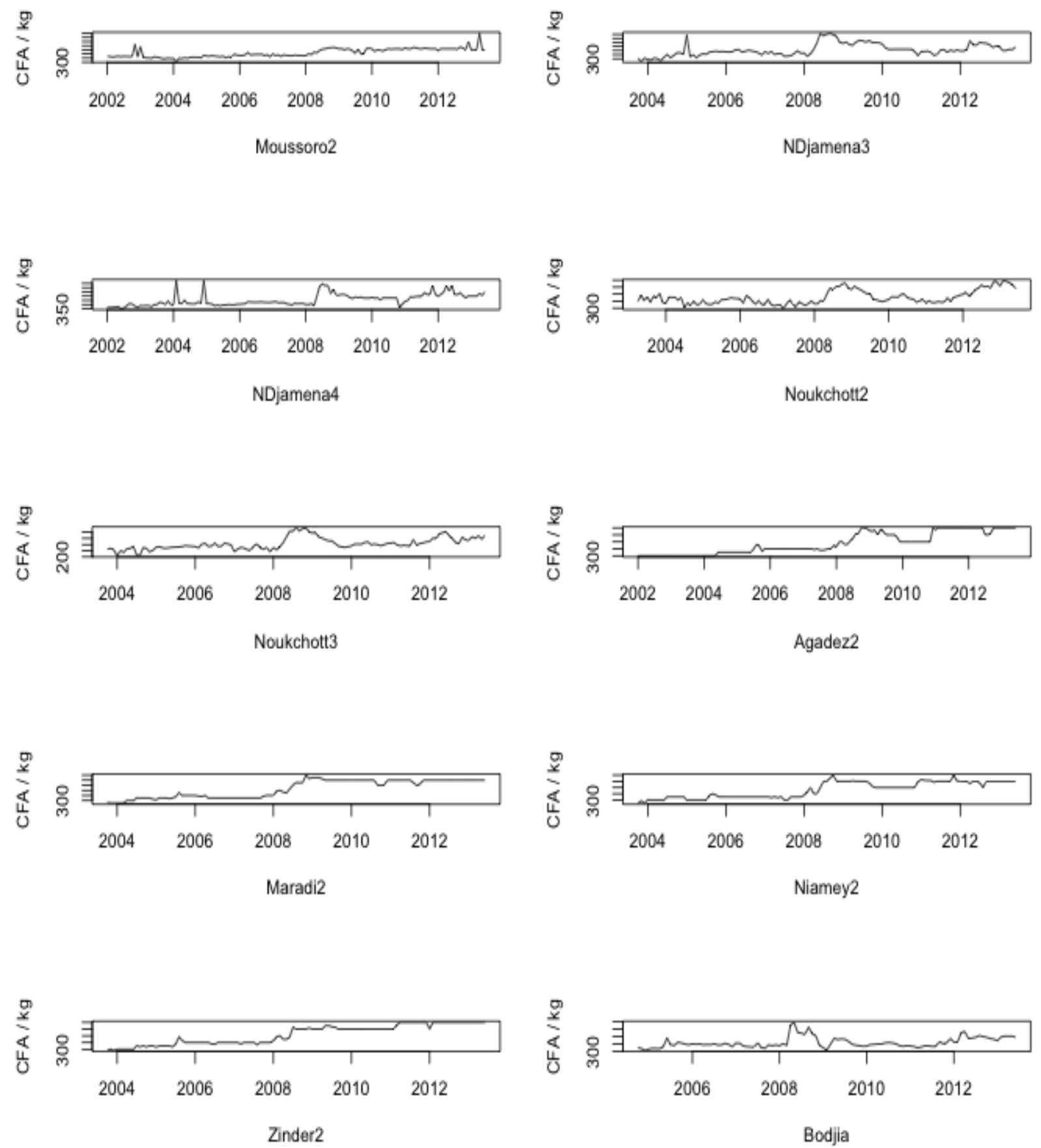
Concluding chapter 
The core results of this dissertation suggest that distance and borders affect spatial price transmission, while other drivers are harder to detect. This is in particular the case for price transmission from the world market to domestic markets. In both literature and own estimations, domestic rice prices tend to be more often cointegrated with the world market price, compared with wheat and maize. The elasticity of price transmission is however the weakest for rice of all three products, while the speed of adjustment is comparable. In the case of maize and wheat domestic prices do most of the adjustment to shocks (most domestic markets are international price takers), but this is not the case for rice. The rice export market is rather thin, which may explain why we find significant price adjustment of the international rice price in many cases. The results do not exhibit clear regional patterns for the transmission from the world market to the domestic level. When comparing all three studies, domestic price series appear to be more often cointegrated with international reference prices compared with other domestic prices. Robust evidence is found for distance and border effects on spatial price transmission, both in the systematic analysis of the literature and based on own estimations in West African rice markets. Geographical distance and crossing a border decreases the likelihood of cointegration. In the meta-analysis also find that these determinants reduce the speed of price adjustment. This confirms previous findings on distance and border effects, as mentioned in the introductory chapter (Amikuzuno \& Donkoh, 2012; HernandezVillafuerte, 2011; Ihle et al., 2010). The results provide evidence for the role of transaction costs related to these factors. Political measures targeted to improve infrastructure and border processing may be possible ways to weaken these impediments.

The strength of this dissertation is the versatile approach to the research question and the different levels in the analysis, see for an overview Table 1. We take different complementary perspectives on price transmission between international export markets and local wholesale and retail markets, as well as on transmission between spatially separated domestic markets in and across countries. The chosen cereal products are relevant in most import-dependent developing regions and in countries in which agriculture plays a large role. We automatized an ECM approach using a large data set. Furthermore, we automatize a comprehensive set of cointegration tests including recent specifications that incorporate threshold effects arising from transaction costs. We complement the procedures with individually modeled estimates from the literature. The two meta-analyses ensure that we do not draw conclusions solely based on one-size-fits-all approaches. Individual estimates from the literature are likely more precise and less likely to suffer from misspecification errors, for example due to disregarded nonlinearities. The West African case study adds a regional focus on a relevant crop in a food deficit region and lays emphasis on the incorporation of transaction costs in the cointegration modeling process. The analyses combine international and regional perspectives on cereal price transmission.

One challenge of the analysis is to capture transaction costs with distance variables. The heterogeneity of infrastructure quality and transport modes between markets results in different cost structures. Geodesic or road distance are therefore imperfect measures of trade costs. Several researchers have suggested to modify the distance measure and include travel hours or sea routes. The availability of travel hours is limited and would have decreased the sizes of the samples at our disposal. To me, none of the available alternative distance measures proved to be objective. In a large number of cases, more than one port is accessible and the assignment becomes subjective. The choice of sea routes and ports depends on the size of the ship, for example whether it fits in as specific port or through a canal, e.g. the Suez canal. An illustrative example is the rice trade route from Chiang Mai in Thailand to N'Djamena in Chad. A relatively short route would be via the port Mombasa in Kenya, with a travel time of 19 days $(13900 \mathrm{~km})$. However, Chad's rice imports arrive via 
Douala, Cameroon ${ }^{21}$, resulting in a travel time of 28 days $(18486 \mathrm{~km})$. Moreover, the trading route via Mombasa involves transiting three additional countries (Uganda, South Sudan and Sudan) with potential costs at each border crossing and check point along the way. A second search tool ${ }^{22}$ finds 8784 nautical miles and 36.5 days for Douala and 4816 nautical miles and 20 days for Mombasa. In this example the obtained travel time differs by $32 \%-45 \%$ depending on the assumptions about the plausible trade route. After long consideration I decided to use only geodesic distance for international market pairs and road distance for regional trade patterns. Future research could focus on specifically modeling nonlinearities of the distance effect originating in the change of transport mode.

Another issue, that became particularly relevant for the West Africa study, is the lack of high quality data. The field of price transmission gave rise to sophisticated methodological developments. More recent models however often require high frequency data. In less developed areas, where food market integration is an important issue, these data are often not available. Data collection is costly for stakeholders in developing countries with limited resources. The international community is addressing this with the collection of monthly food price data such as FAO-GIEWS, USAID-FEWS or WFP-VAM, however higher frequency data is not available. For the case study in West Africa sufficiently long price series were available for only 6 countries. This complicates the examination of macro variables used in gravity models for trade (see introductory chapter).

\footnotetext{
${ }^{21}$ See the direction of trade flows of the Production and market flow map: West Africa. by FEWS NET, US Agency for International Development (USAID), online available on www.fews.net/west-africa/production-andtrade-flow-maps/thu-2009-10-22-3 (accessed 17 Mai 2014)

22 www.sea-distances.org (accessed on 17 May 2014)
} 
Table 3: Overview about the different perspectives used in the dissertation chapters

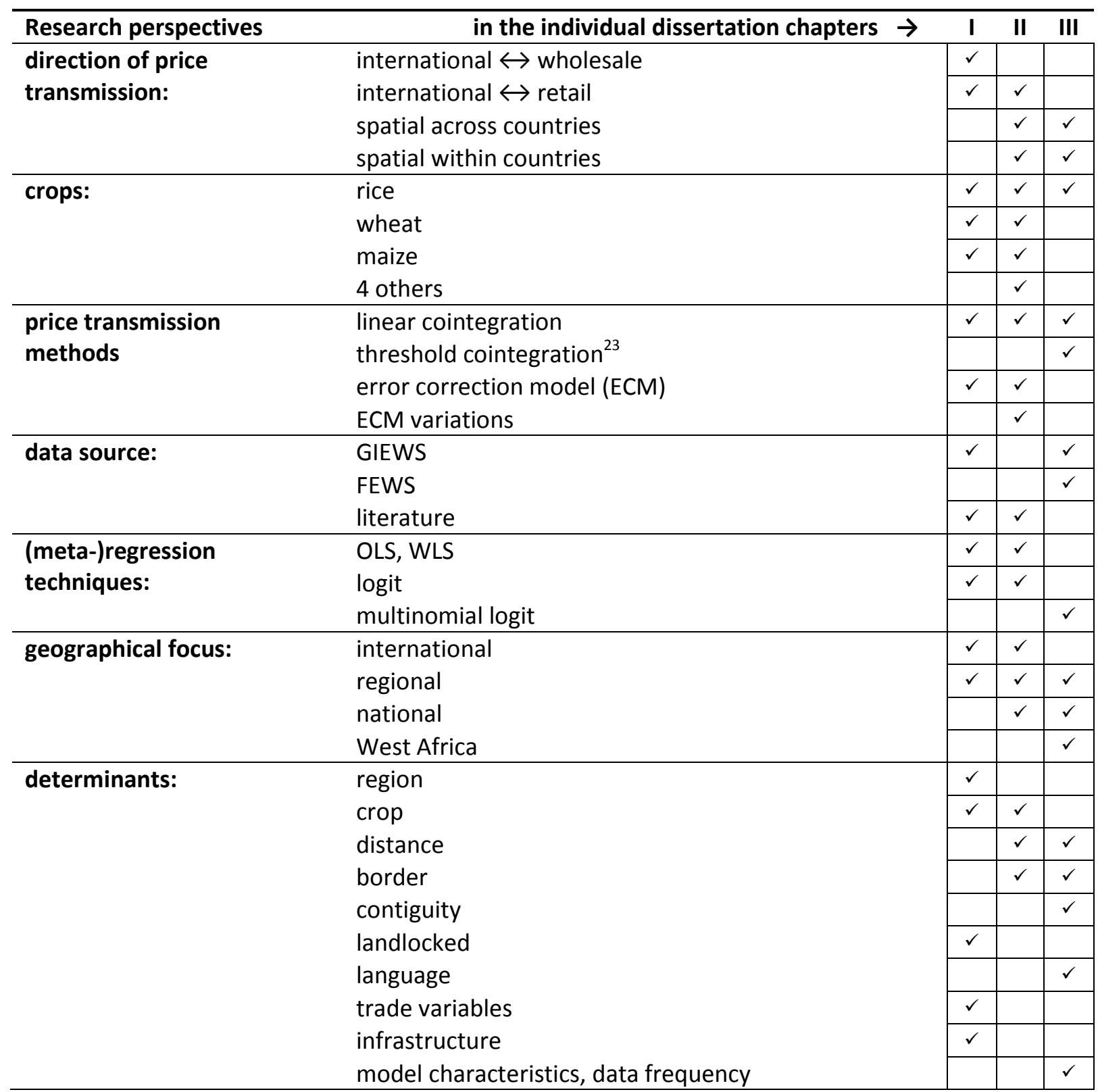

Note: A checkmark indicates that this particular variable or method was used in the corresponding dissertation chapter.

The meta-analytical approaches were a challenge with regard to the time frame of this dissertation. Meta-analysis is a powerful tool for experienced researchers in a specific field. It is advisable to search studies with rigorous criteria and search keywords and strictly limit the number of extracted variables from the start. An exhaustive study search is neither possible nor necessary to produce results within a reasonable amount of time. In chapter two, the exclusion of estimates from nonlinear model specifications and grey literature studies would, viewed with hindsight, have not have notably influenced the main results. Instead, the analysis could have been extended to other food products. We chose to average estimates from nonlinear model types over the size of their specific regime, but this is certainly a debatable approach. In the estimation, the sample proved to be

\footnotetext{
${ }^{23}$ As in most parts of the literature, here the term threshold cointegration is used to describe linear cointegration with threshold effects in the price adjustment. For the full definition please refer to the method section (3.) in chapter three.
} 
very fragmented and required drawing subsamples for different models in order to ensure comparability of the respective variables. The first meta-analysis in chapter one uses a partly inconsistent sample because the included models are not all directly comparable. For example, parameters from ARDL and error correction models are compared, as are annual data and monthly data, even though Von Cramon-Taubadel et al. (2003) show that data frequency has an influence in the results of price transmission estimates.

Some difficulties emerged in the preparation of working on the third chapter. The work on regional rice market integration in West Africa developed out of another research project on Senegal. The study was planned as a case study of spatial price transmission among 21 retail markets and integration with the respective international reference price. Senegal was chosen for the reason of its high dependence on rice imports as its main staple (Brüntrup et al., 2006). I estimated price transmission with a TVECM approach (Greb et al., 2013) and pretested a trader survey. ${ }^{24} \mathrm{After}$ several months of work, we discovered by chance that $60-80 \%$ of the underlying price data had been interpolated, although the source of the data had not indicated this to us. As a result, we were forced to discontinue this research. Instead, based on available data from other sources, we decided to focus on the West African region using macro-level variables rather than survey data.

In the light of the third chapter, the question emerged whether regional economic agreements positively influence agricultural market integration. We explored the effects of both markets sharing the same currency and of both markets being part of the West African Economic and Monetary Union (WAEMU/UEMOA) or of the Economic Community of West African States (ECOWAS/CEDEAO). None of these three variables showed a robust positive effect. On the contrary, in some specifications a statistically significant negative effect on linear cointegration and threshold cointegration appeared. The sample of 6 countries is however too small for reliable interpretation. For future research, this could be worthwhile investigating, preferable on the basis of a larger geographical scope and more than one agricultural product. If length and frequency of the data allow this, a complementary TVECM approach could be applied. A more thorough analysis could explore the determinants of the obtained estimates for the speed of price adjustment and the size of the thresholds as proxies for spatial transaction costs. Controlling for distance and border effects, such an analysis could produce insights into whether trade agreements or currency unions decrease transaction costs and accelerate the speed of price transmission.

We mentioned in the third chapter the role of communication for the transmission of price changes even if no trade takes place between markets (Jensen, 2007; Stephens et al., 2012). The ease of communication could be approximated by different variables such as a common language or culture, but also the availability of information and communication technology (ICT). Such data are available on the country level and could be collected on the market level (Aker \& Fafchamps, 2010; Aker, 2010; Aker et al., 2013). Price transmission usually occurs via spatial arbitrage as the main channel. ICT might have an influence on trade patterns when market participants use it to access price information in other markets. In absence of trade, ICT might itself constitute a channel for price transmission if market participants adjust to price signals in other markets. One could test the hypothesis, that there is an effect of ICT on price transmission and that this effect differs for markets that trade with one another and for markets that do not trade. A corresponding sample would include market pairs with and without access to ICT, both with and without bilateral trade flows. The trading markets constitute the counterfactual for the non-trading markets, so that the effect of ICT on price transmission is isolated from that of trade itself. A potential challenge is posed by unobserved trade flows, for example through smuggling (Golub, 2012).

\footnotetext{
${ }^{24}$ We are grateful to Friederike Greb for providing us with the estimation code and to Jenny Aker for providing us with the questionnaires of her work in Niger and Nigeria (Aker et al., 2013).
} 


\section{References}

Aker, J. (2010). Information from markets near and far: Mobile phones and agricultural markets in Niger. American Economic Journal: Applied Economics, 2, 46-59.

Aker, J., \& Fafchamps, M. (2010). How Does Mobile Phone Coverage Affect Farm-Gate Prices ? Evidence from West Africa. Tufts University Working Paper, 1-50.

Aker, J., Klein, M., Connell, S., \& Yang, M. (2013). Borders, Ethnicity and Trade. Tufts University Working Paper Series, 1-72.

Amikuzuno, J., \& Donkoh, S. A. (2012). Border effects on spatial price transmission between fresh tomato markets in Ghana and Burkina-Faso: Any case for promoting trans-border trade in West Africa? Journal of International Agricultural Trade and Development, 8(1), 81-98.

Brüntrup, M., Nguyen, T., \& Kaps, C. (2006). The rice market in Senegal. Agriculture \& Rural Development, German Development Institute - DIE, 22-25.

Golub, S. (2012). Entrepôt Trade and Smuggling in West Africa: Benin, Togo and Nigeria. The World Economy, 35(9), 1139-1161.

Greb, F., von Cramon-Taubadel, S., Krivobokova, T., \& Munk, A. (2013). The estimation of threshold models in price transmission analysis. American Journal of Agricultural Economics, 95(4), 900 916.

Hernandez-Villafuerte, K. (2011). The relationship between spatial integration and geographical distance in Brazil. Annual Meeting of the European Association of Agricultural Economics (EAAE), Zürich, Switzerland, 1-37.

Ihle, R., von Cramon-Taubadel, S., \& Zorya, S. (2010). Country and border effects in the transmission of maize prices in Eastern Africa: evidence from a semi-parametric regression model. Annual Meeting of the African Association of Agricultural Economists (AAAE), Cape Town, South Africa, $1-33$.

Jensen, R. (2007). The digital provide: Information (technology), market performance, and welfare in the South Indian fisheries sector. The Quarterly Journal of Economics, CXXII (3), 879-924.

Stephens, E., Mabaya, E., von Cramon-Taubadel, S., \& Barrett, C. (2012). Spatial Price Adjustment with and without Trade. Oxford Bulletin of Economics and Statistics, 74(3), 453-469.

Von Cramon-Taubadel, S., Loy, J.-P., \& Meyer, J. (2003). The impact of data aggregation on the measurement of vertical price transmission: evidence from German food prices. Annual Meeting of the American Agricultural Economics Association (AAEA), Montreal, Canada, 1-17. 